\title{
HYGIENIC QUALITY OF CHLORINATED CITY WATER STORED IN HOUSEHOLD TANKS IN BYBLOS, LEBANON
}

\author{
by
}

Najib Abi Chedid

A thesis submitted in partial fulfillment of the requirements for the Degree of Masters of Science

Microbiology

Lebanese American University

2003

Under the Supervision of Dr. Fuad Hashwa 


\section{LEBANESE AMERICAN UNIVERSITY}

Graduate Studies

Approved by Dr. Fuad Hashwa

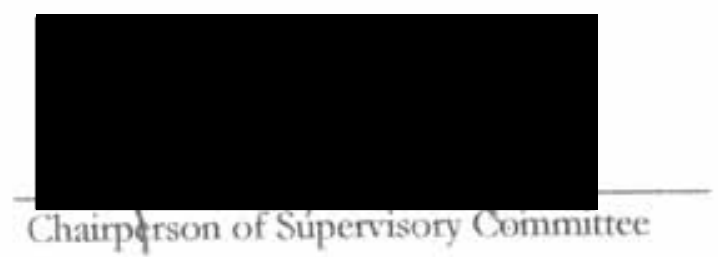

Dr. George Baroudy

Dr. Costantine Daher

Dr. Roy Khalaf

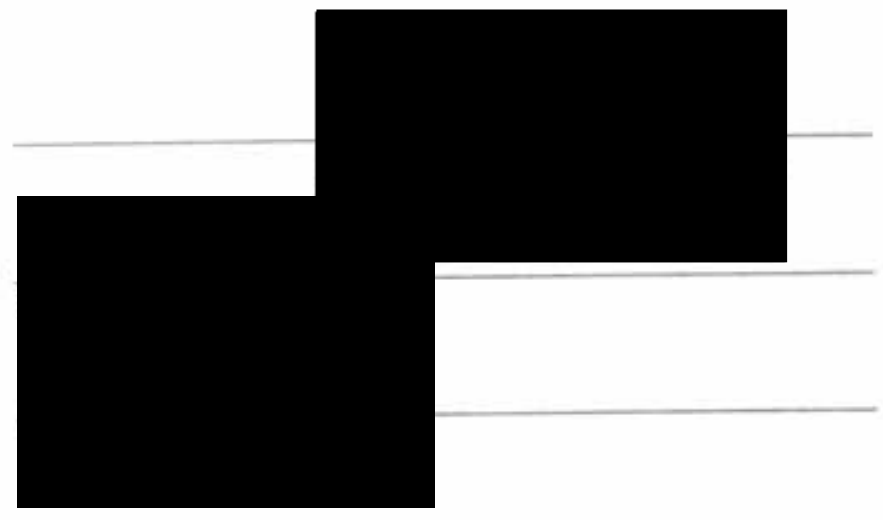

Program Authorized
to Offer Degree

Date

04.03 .2004 
I grant to the LEBANESE AMERICAN UNIVERSITY the right to use this work, irrespective of any copyright, for the University's own purpose without cost to the University or to its students, agents and employees. I further agree that the University may reproduce and provide single copies of the work, in any format other than in or from microfilms, to the public for the cost of reproduction.

Najib A. AbiChedid Nä̈bA.Chedid. 


\section{LEBANESE AMERICAN UNIVERSITY}

ABSTRACT

\section{HYGIENIC QUALITY OF CHLORINATED CITY WATER STORED IN HOUSEHOLD TANKS IN BYBLOS, LEBANON}

by

Najib Abi Chedid

Chairperson of the Supervisory Committee: Professor Fuad Hashwa

Division of Natural Science

Countries suffering from water shortage problems use the intermittent mode of supply where water is pumped for few hours once or twice a week, which forces householder to store water in tanks located on rooftops or in reservoirs beneath the house. Water stored for several days may rapidly deteriorate imposing health risks on consumers.

The first part of this study aimed at the examination of the microbial populations present in different household water storage tanks, and to examine the extent and the phenomenon of this microbial regrowth and determine the factors involved in it.

The heterotrophic plate count (HPC) of the household water storage tanks in Byblos city, Lebanon ranged from $5 \mathrm{CFU} / \mathrm{mL}$ to $4 \times 10^{4} \mathrm{CFU} / \mathrm{mL}$. A significant difference was not detected in the total bacterial count in the samples collected from the different types of tanks (black polyethylene, fiberglass, asbestos (eternite) and galvanized cast iron). Psendomonas ( $P$. aenuginosa, 26.2\%) was the dominant type observed, while Bacillus (B. ampldiquefaciens, $9.63 \%$ ) was the next dominant organism isolated from the storage tanks. 
Opportunistic pathogens such as $P$. aenugimosa (2 of 7 samples), E. sakazakii (2 of 7 ), E. agglomerans ( 1 of 7 ) and Aeromonas sobria (1 of 7), in addition to the dominant bacterium Bunkbolderia copacia (5 of 7) were detected in the drinking water samples collected from Byblos city. The presence of such opportunistic pathogens could be attributed to inefficient chlorination. Thus the city drinking water is not of acceptable microbiological condition after reaching consumers due to the considerable occurrence of such microorganisms. However, $P$. aenuginasa and coliforms were not detected in the UV treated drinking water samples.

The effect of water retention time on bacterial regrowth pattern in the chlorinated city fiberglass tank was studied. Results obtained indicated bacterial regrowth with the dominant species being Psendomonas spp. Bacterial exponential growth occurred during the first 5 days with an HPC increase of 1400 fold ( $20 \mathrm{CFU} / \mathrm{mL}$ to $28000 \mathrm{CFU} / \mathrm{mL}$ ), compared to an increase of only 1 -fold during the period between 5 and 7 days storage time. In the UV treated water 9 to 16 -fold increase in the HPC level was detected after 2 and 4 days of storage in the PE and cast iron tanks, respectively.

In the UV treated water storage tanks, data showed that the frequencies of occurrence of gram-negative bacteria were $54 \%$ in the cast iron, $83 \%$ in the $\mathrm{PE}$ and $75 \%$ in the influent water. In the chlorinated city water tanks, the frequencies of occurrence of gram-negative bacteria were $86 \%$ in the cast iron, $50 \%$ in the PE, and $87 \%$ in the influent water.

Chlorination experiments performed on the water stored in the PE tanks showed that maintaining a free residual chlorine $\geq 0.25 \mathrm{mg} / \mathrm{L}$ was enough to control the HPC, while a 271-fold decrease (27100 CFU/mL to $100 \mathrm{CFU} / \mathrm{mL})$ of $\mathrm{HPC}$ bacteria occurred at a free chlorine of $0.11 \mathrm{mg} / \mathrm{L}$. The gram-positive Connebacterimm uariabilis survived free $\left[\mathrm{C}_{2}\right] \leq 0.17$ $\mathrm{mg} / \mathrm{L}$ in the water of PE tanks. On the other hand, maintaining a free residual chlorine $\geq 0.35 \mathrm{mg} / \mathrm{L}$ was enough to control HPC levels in the cast iron tanks. In contrast to the PE tanks, some bacteria survived in the presence of $0.26 \mathrm{mg} / \mathrm{L}$ and $0.19 \mathrm{mg} / \mathrm{L}$ of free chlorine in the cast iron tanks. At $0.19 \mathrm{mg} / \mathrm{L}$, endospore-forming gram-positive Bacilli 
were the dominant types detected, while at $0.26 \mathrm{mg} / \mathrm{L}$ an organism suspected to be Myobacterim was detected.

This study showed that $91.2 \%$ of the gram-negative bacterial isolates could be identified by the Biolog system, whereas only $82.5 \%$ were identified by the API system. The percentage of isolates that were assigned the same identity (genus $\&$ species) by both systems was $24.6 \%$. Moreover $33.3 \%$ were not similar at the genus level, while $15.8 \%$ were not similar at the species level. Difficulties encountered in the identification of these bacteria were possibly due to the oligotrophic nature of these isolates. However, $89 \%$ of the grampositive bacterial isolates were identified using the Biolog system.

Identification of 31 isolates belonging to Psendomomas however, revealed better agreement in the results at both the genus and species level. The percentage of isolates that were assigned the same identity by both systems was $45.2 \%$. Differences were seen between both systems, where $9.68 \%$ and $35.5 \%$ of the isolates using the API were assigned to different species or genera, respectively. However, $6.45 \%$ were identified as $P$ sendomonas by the Biolog and not identified by the API, and $3.22 \%$ were identified as Psendomonas by the API and not identified by the Biolog. Furthermore, among the coliform group isolated and belonging to 2 genera Citrobacter and Enterobader, both systems showed $100 \%$ similarity at the genus level, and no similarities at the species level. 


\section{TABLE OF CONTENTS}

Table of contents

List of figures

List of tables

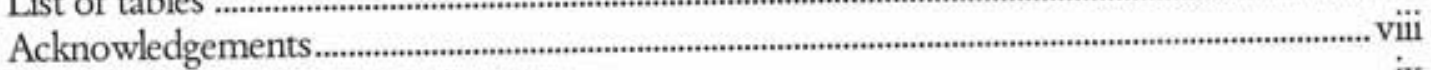

Glossary......................................................................................................................................

Chapter 1 …............................................................................................................................... 1

General Introduction ................................................................................................................... 1

1.1 Drinking water quality in household water storage tanks.................................... 1

1.2 Specific objectives of this study ............................................................................ 5

Chapter 2

.6

Literature Review.................................................................................................................... 6

2.1 Introduction ......................................................................................................... 6

2.2 Groundwater habitat .................................................................................................

2.2.1 Biological component .............................................................................

2.3 Starvation-survival lifestyle...................................................................................... 8

2.3.1 The viable but non-culturable (VBNC) state ............................................ 8

2.4 Bacterial regrowth in water distribution systems ................................................. 9

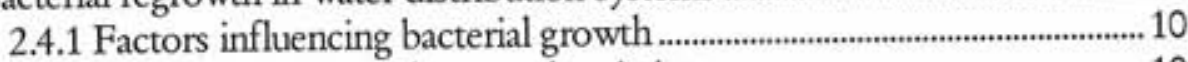

2.4.1.1 Temperature and seasonal variation ................................................... 10

2.4.1.2 Nutrients................................................................................................ 11

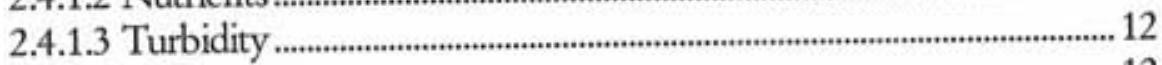

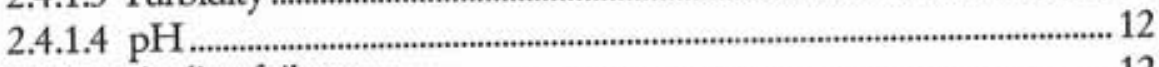

2.4.1.5 pipeline failure ..................................................................................... 12

2.4.2 Survival of bacteria in drinking water distribution systems................... 13

2.4.3 Survival of protozoa in drinking water distribution systems ..................13

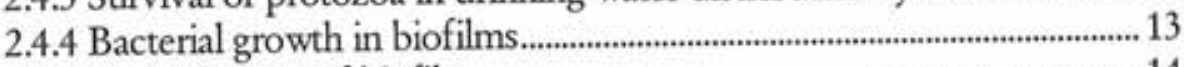

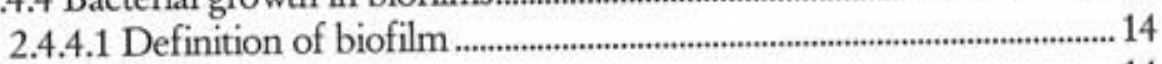

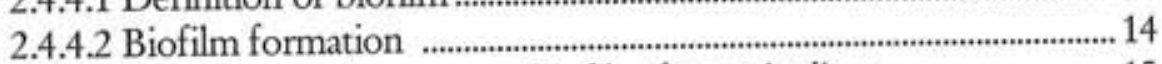

2.4.4.3 Remedies used to remove biofilm from pipelines ........................... 15

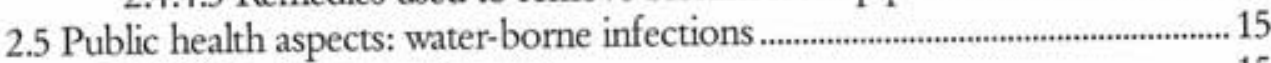

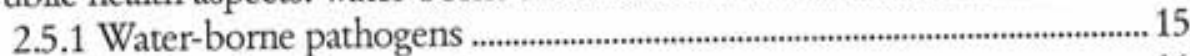

2.5.1.1 Pseudomonas aeruginosa .....................................................................16

2.5.1.2 Burkholderia cepacia.............................................................................16

2.5.1.3 Aeromonas sp. (A. hydrophila)........................................................17

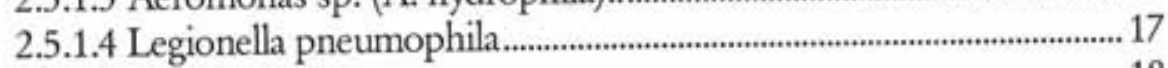

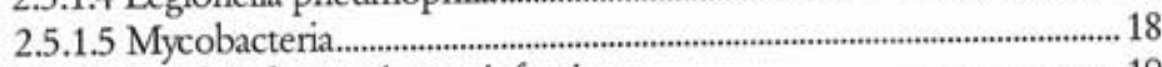

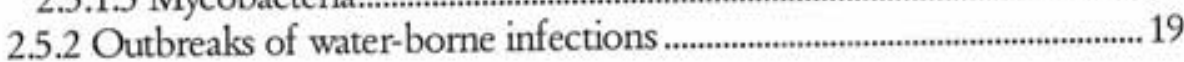


2.6 Microbiological examination of drinking water: Rationale .................................19

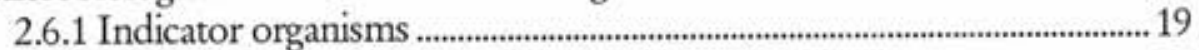

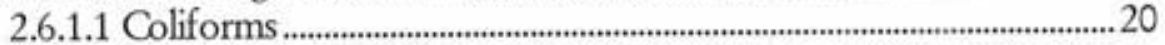

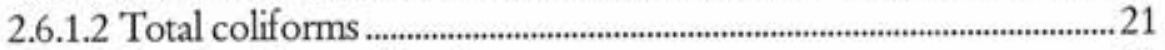

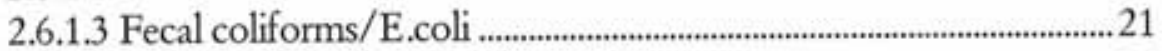

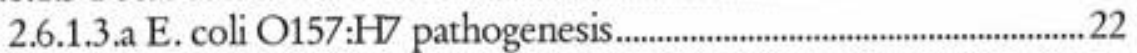

2.6.1.4 Coliforms in drinking water.............................................................22

2.6.1.5 Survival of coliforms in water...........................................................22

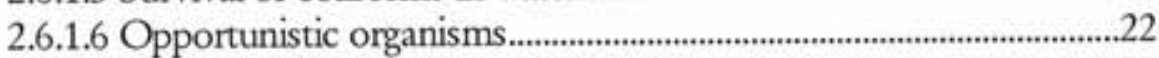

2.7 Heterotrophic bacteria isolated from drinking water...........................................23

2.8 Uses of inorganic hypochlorite in water treatment .............................................25

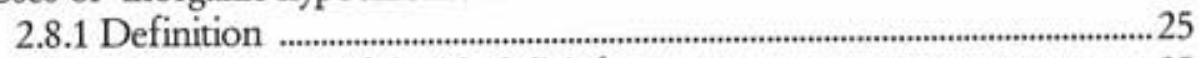

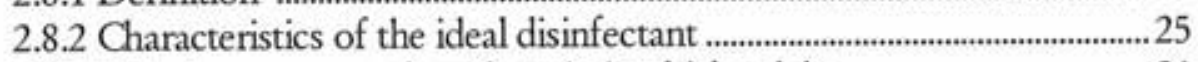

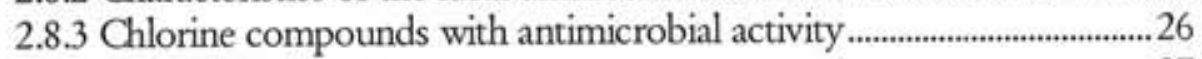

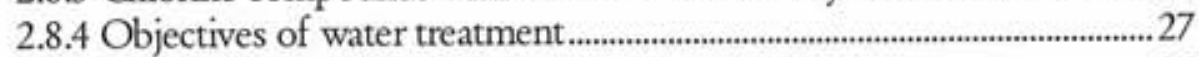

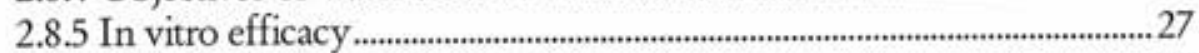

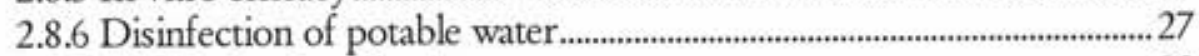

2.8.6.1 Mechanism of action ........................................................................28

2.8.6.2 Effect of $\mathrm{pH}$ on bactericidal activity ................................................28

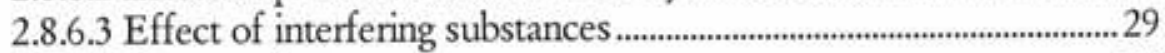

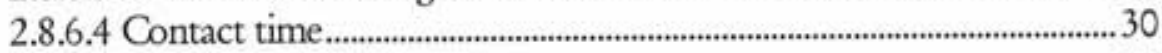

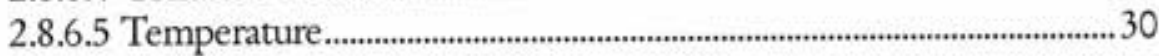

Chapter 3

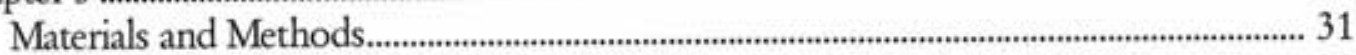

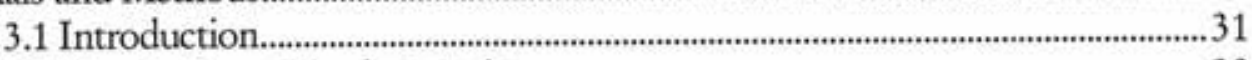

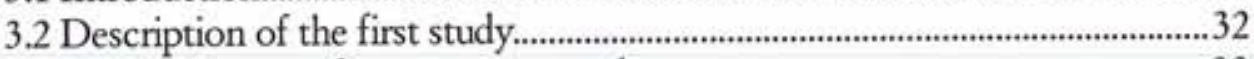

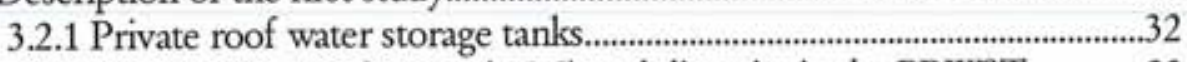

3.2.1.1 Total bacterial count (HPC) and diversity in the PRWST...............33

3.2.1.2 Effect of water storage on total bacterial counts.................................34

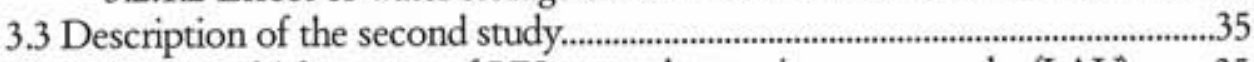

3.3.1 Microbial content of UV- treated water in storage tanks (LAU)..........35

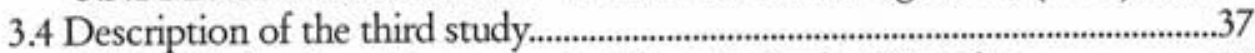

3.4.1 Chlorination effect on bacterial counts in the PE tanks.........................37

3.5 Samples' collection from the PRWST................................................................38

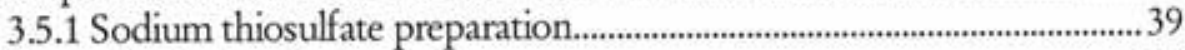

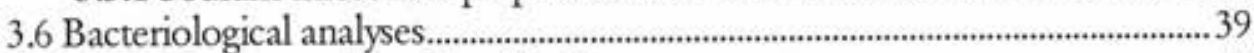

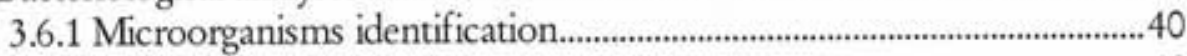

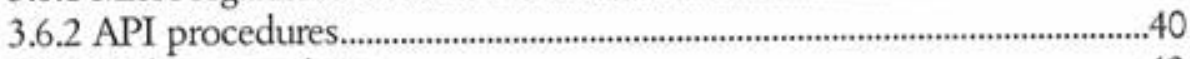

3.6.3 Biolog procedures....................................................................................42

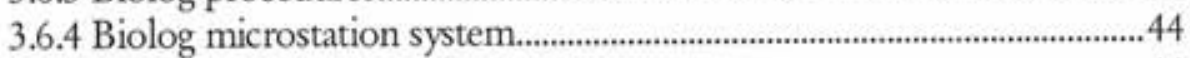

3.6.4.1 Inoculum preparation........................................................................44

3.6.4.2 Efficiency of the Biolog system: BUGMvs. TSA....................... 47

3.7 Physico-chemical analyses................................................................................ 47 
Chapter 4 . .48

Results

4.1 Spreading vs. filtration technique vs. HPC..........................................................48

4.2 Microbiological quality of the water in the PRWST............................................50

4.3 Microbiological quality of the influent drinking water......................................57

4.3.1 Bacterial distribution in the influent drinking water..............................57

4.4 Physico-chemical parameters results in the PRWST.......................................59

4.5 Effect of RT on the microbial regrowth in the fiberglass tank......................59

4.6 HPC levels in the UV treated water storage tanks..........................................61

4.7 Bacterial population in the UV treated vs. the chlorinated water tanks........62

$4.8 \mathrm{Cl}_{2}$ effect on HPC levels in the PE and cast iron water storage tanks..........66

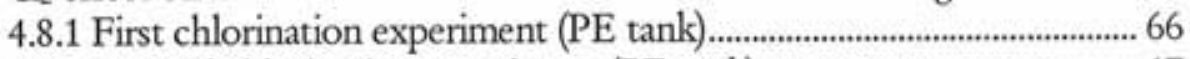

4.8.2. Second chlorination experiment (PE tank)........................................ 67

4.8.2.1 Reverse mechanism of chlorination...................................................68

4.8.3 Third chlorination experiment (PE tank)............................................69

4.8.4 Chlorination runs on the water stored in the cast iron tank.................71

4.9 Microbial identification systems Biolog vs. API ............................................73

Chapter 5 . .76

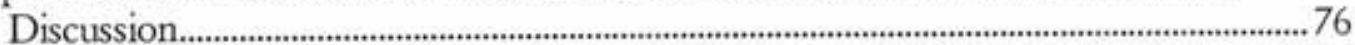

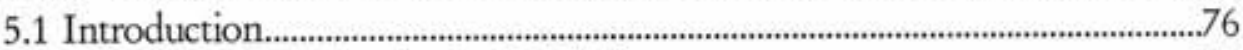

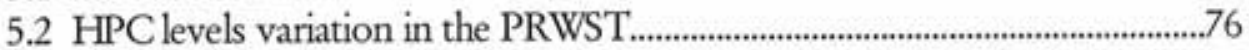

5.3 Gram-negative bacteria in the PRWST......................................................77

5.4 Gram-positive bacteria in the PRWST and the influent water.................78

$5.5 \mathrm{HPC}$ in the influent water vs. the PRWST.................................................79

5.6 Effect of RT on the microbial diversity of 3 types of tanks.....................79

5.7 Percentage of G-/G+ bacteria in the UV treated vs. chlorinated water......80

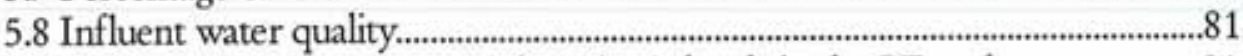

5.9 Chlorination effect on HPC diversity \& levels in the PE tank......................81

5.9.1 Reverse mechanism of chlorination .......................................................82

5.10 Chlorination effect on HPC diversity \& levels in the cast iron tank..........82

5.11 Microbial identification systems: Biolog vs. API..........................................83

5.12 Hygienic aspect of the city influent drinking water and the PRWST..........85

5.12.1 Minor occurrences of other gram-negative non enteric bacteria........85

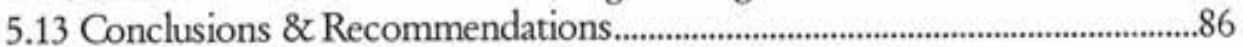




\section{LIST OF FIGURES}

Page

Figure 1: Fiberglass (A), eternite (Asbestos, B) and polyethylene(C). Tanks installed on the roof top of a building in Byblos city.

Figure 2: The galvanized cast iron tanks placed on the same roof top.

Figure 3: The cast iron and PE tanks (each of 500L capacity) installed at the Lebanese American University (LAU), Byblos.

Figure 4: A diagram of the water supply distribution system at LAU.

Figure 5: Experimental chlorinated PE water storage tank compared with the control tank.

Figure 6: Calcium hypochlorite tablets (Citernet) used in chlorination.

Figure 7: A set of three API-20E strips each consisting of 20 tests.

Figure 8: A 96 well plate of inoculated suspension of Bacillus lidheniformis.

Figure 9: Biolog identification system composed of the microtiter reader and the computer based identification system.

Figure 10: Inoculation of bacterial suspension with an eight-channeled repeating pipette in a Biolog microtiter plate. 
Figure 11: Bacillus myouides a GP-ROD SB identified by the Biolog system.

Figure 12: A GN- NENT bacterium identified as Psendomonas aeriginosa.

Figure 13: Hach pocket colorimeter used for residual free chlorine and total chlorine testing.

Figure 14: Spreading vs. filtration microbiological technique related to HPC levels in the PE water storage tanks.

Figure 15: Spreading vs. filtration microbiological technique related to $\mathrm{HPC}$ levels in the cast iron water storage tanks.

Figure 16: Percentage of samples positive for $P$. aernginosa, total and fecal coliforms and HPC bacteria.

Figure 17: Summary of total HPC in the PRWST and the influent water.

Figure 18: Left: Filamentous growth of Bacillus mowides. Right: a red-pigmented strain of Streptomyces.

Figure 19: Percentage of samples positive for $P$. aeruginosa, total and fecal coliforms and HPC bacteria in the influent water.

Figure 20: $\log$ HPC vs. water storage time (days) in the fiberglass tank.

Figure 21: $\mathrm{HPC}$ vs, water storage time in the PE tank (chlorination experimental tank).

Figure 22: HPC vs. water storage time in the cast iron tank (chlorination experimental tank). 
Figure 23: $\mathrm{HPC}$ vs. $\left[\mathrm{Cl}_{2}\right]$ in the PE water storage tank (1 ${ }^{\text {st }}$ run).

Figure 24: Effect of $\left[\mathrm{Cl}_{2}\right]$ levels on $\mathrm{HPC}$ in the PE water storage tank (2 ${ }^{\text {nd }}$ run).

Figure 25: HPC vs. water storage time in the control PE tank ( $2^{\text {nd }}$ run).

Figure 26: Reverse mechanism of water chlorination:

$\mathrm{HPC}$ vs. $\left[\mathrm{C}_{2}\right]$ vs. water storage time in the PE tank.

Figure 27: $\mathrm{HPC}$ vs. $\left[\mathrm{C}_{2}\right]$ vs. water storage time in the PE tank (3rd run).

Figure 28: HPC vs. water storage time in the control PE tank (3ri run).

Figure 29: $\mathrm{HPC}$ vs. $\left[\mathrm{C}_{2}\right]$ vs. water storage time in the cast iron tank. 


\section{LIST OF TABLES}

Table 1: Bacteriological quality of water in the household roof water storage tanks and the drinking water inlet (distribution system)

Table 2: Percentage occurrences (count wise) of the gram-negative bacteria isolated from the PRWST

Table 3: Percentage occurrences of the gram-positive bacteria isolated from the PRWST

Table 4: Number of occurrences of the gram-negative and gram-positive bacteria isolated from the PRWST and the influent water

Table 5: Maximum, minimum and average values for the physicochemical parameters in the PRWST

Table 6: Bacterial population isolated from PE water storage tanks (city \& LAU)

Table 7: Bacterial population isolated from the cast iron water storage tanks (city \& LAU)

Table 8: Bacterial population isolated from influent water (PRWST \& LAU)

Table 9: Bacterial population in the experimental chlorinated water in the cast iron tank

Table 10: Identification of bacterial strains according to Biolog GN and API-20NE/API-20E for 24 to $48 \mathrm{~h}$ incubation 


\section{ACKNOWLEDGMENTS}

"Knowledge cultivates your seeds and does not sow in you seeds." (Khalil Gibran)

It is a great honor to me to have worked with Dr. Fuad Hashwa, my advisor, whom I am indebted to for providing me all sincere guidance throughout this research, and throughout my M.S. studies.

My thanks are also due to the members of the committee, Dr. George Baroudy, Dr. Costantine Daher and Dr. Roy Khalaf.

I would also like to thank Dr. Sima Tokajian for her sincere guidance and technical support during this study.

I would like to thank Miss Helena Bou Farah, and Mr. Jean Karam, for their appreciated assistance.

I would like to express my sincere gratitude to the Lebanese American University whose financial support during my graduate studies made it all possible.

Special thanks are also due to Dr. Najib Haddad, Mr. Bechara Mfarrej and Mr. Elias Mhanna for their support and to all my colleagues who graduated with an MS. degree in Molecular Biology at LAU, Byblos.

My deepest thanks are due to my beloved family, especially my mother who tolerated and supported me morally throughout this research and throughout all my study years.

Finally, I would like to express my warm appreciation to Miss Natasha Magarina and Miss Eugenie Gouskova who shared me this part of my life. 


\section{GLOSSARY}

AO: Acridine orange

AOC: Assimilable organic carbon

BCAA: Bromochloroacetic acid

BDOC: Biodegradable dissolved organic carbon

BOM: Biodegradable organic matter

CBP: Chlorination by-products

CFU: Colony-forming unit

CT: Contact time

DBAA: Dibromoacetic acid

DBCM: Dibromochloromethane

DCBM: Dichlorobromomethane

DCAA: Dichloroacetic acid

D/DBP: Disinfectant/disinfection by-products

DOC: Dissolved organic carbon

EPA: Environmental protection agency

HAA: Haloacetic acid

HOCl: Hypochlorous acid

HPC: Heterotrophic plate count

MBAA: Monobromoacetic acid 
MCAA: Monochloroacetic acid

MCL: Maximum contaminant level

$\mathrm{Mm}^{3}$ : Million cubic meter

NDMA: Nitrosodimethylamine

NOM: Natural organic matter

NTM: Nontuberculous mycobacteria

NTU: Nephelometric unit

PE: Polyethylene

PPM: Parts per million (equivalent to $\mathrm{mg} / \mathrm{L}$ )

PRWST: Private roof water storage tanks

RT: Residence time

TCAA: Trichloroacetic acid

THM: Trihalomethanes

TOC: Total organic carbon

UV: Ultraviolet

VBNC: Viable but non culturable

WHO: World health organization 


\section{Chapter 1}

\section{GENERAL INTRODUCTION}

\subsection{Drinking Water Quality in the Household Water Storage Tanks}

Water resources of Lebanon are derived mainly from rainwater, snow, and surface water. About $70 \%$ of Lebanon is made of calcareous rocks, mainly fractured and cavernous limestone. The presence of impermeable rocks intercalation serves in restricting groundwater in aquiferous formations. The depth of these wells varies from 50 to $300 \mathrm{~m}$ depending on the aquifer with an average of about $150 \mathrm{~m}$. The over-pumping from these wells is considered as the major reason of salt water intrusion especially in coastal strip (Plassard, 1992).

About 2500 major springs discharge in Lebanon in addition to large number of minor springs with fewer yields. A realistic estimation of water volume from these springs is 1150 $\mathrm{Mm}^{3} /$ year (Plassard, 1992).

In Lebanon, most populated areas receive ground water originating from artesian wells. This water is first subjected to physical and chemical treatment processes to remove potentially harmful microorganisms and chemical pollutants from drinking water. Physical removal of contaminants is achieved by means of flocculation, sedimentation, and filtration. Pre-treatment process includes the addition of chemicals to water which will aid in coagulation and $\mathrm{pH}$ control. Chemical treatment of drinking water usually involves adding a chemical disinfectant such as chlorine, chloramines, chlorine dioxide, or ozone. Chemicals are added throughout a process called "Rapid Mixing"(EPA, 1986). As of physical removal of contaminants, flocculation processes small particles (i.e. clay and silt, natural organic matter, microbial contaminants, and toxic metals) into larger particles. This "clumping" is called coagulation. Sedimentation process promotes settling of solid particles to the bottom of a settling basin. Once settled, the solids are removed from the water. Whereas filtration process promotes the removal of all remaining particles by forcing the water through layers of charcoal, sand, and gravel which provide clear and cleaner water. 
Post treatment process includes the addition of chlorine to reduce bacteria, and other chemicals to make the water taste better. By treating drinking water in this manner, an important contribution to public health protection could be achieved by eliminating the threat of many waterborne diseases (such as cholera and typhoid fever) which caused significant death rates at the start of the 20 th century $(\mathrm{EPA}, 1999)$ ). Water is stored after all treatment processes in large storage tanks until needed by users. Water is then distributed to residents from the storage tank through a series of pipes known as a "distribution system".

The purpose of a water supply distribution system is to deliver safe drinking water that is also adequate in quantity and acceptable in terms of taste, odor, and appearance (WHO, 1993). Water supply release into the distribution system becomes altered during its passage through pipes, open reservoirs, standpipes, and storage tanks (Geldreich, 1996). In many developing countries, municipal water is unsafe because of inadequately maintained pipes, low pressure, intermittent delivery, and clandestine connections (Ford \& Colwell, 1996), implying possible consequences to the microbiological quality of the drinking water itself (Hashwa \& Tokajian, 2000).

To protect the distribution system from contamination and the buildup of biofilm (a community of microorganisms attached to a solid surface) a positive water pressure of more than 20 psi should be maintained throughout the entire pipe network. However, due to the excessive consumer demand, failure of source water of supply, poor maintenance and excessive distribution system leakage, the water distribution system acts under reduced pressure conditions most of the time. Reduced pressure in the distribution system is always a threat to water quality and dictates the need for free chlorine residual in all sections of the system to provide protection from the possibility of contaminant intrusions.

Naturally groundwater is of excellent microbiological quality and generally of adequate chemical quality. This is due to the soil barrier providing effective isolation from surface pollutants (Foster, 1995). In recent years there has been a growing suspicion that the protection of groundwater quality is not always assured by a soil barrier and therefore the contamination of groundwater from different sources occurs worldwide. 
This contamination is due to the large variety of materials used by industries and households. The disposal of toxic waste, municipal solid waste, sewage sludge, industrial waste \& effluent are some examples of groundwater pollution sources (Engelbrecht, 1993). As a result of contamination, heterotrophic and coliform bacteria can be found in groundwater. Pathogens may exist in groundwater for up to 40 days given favorable conditions and reasonable levels of nutrients (Chilton $e$ al., 1995). Reports of outbreaks of waterborne diseases and unsatisfactory coliform counts have led to the recommendation to disinfect many well waters and springs used for drinking (Lippy \& Waltrip, 1984). Providing adequate amounts of drinking water of an acceptable quality is a basic necessity. Failure to do so may expose the population to waterborne diseases. Those at greatest risk are the very old, the very young, and immunosuppressed patients in hospitals (WHO, 1993).

In developing countries, fast growing population combined with poor living conditions in rural areas have forced many people to migrate to cities in search of better living conditions (Mintz ot al., 1995). Urbanization affects water availability and subsequently water quality. This growing water stress in urban areas has placed much emphasis on storing water from the public distribution system into private water storage tanks.

However, water distribution in Lebanon is rationed and residents receive water intermittently thus water is stored in private roof water storage tanks (PRWST) in order to meet the consumers' demand. Household water storage tanks are made of different materials including cement, eternite (Asbestos), galvanized cast iron, polyethylene, and fiberglass. Tanks are usually elevated on the roofs of buildings, underground or at ground level. Almost the whole population of Byblos city is served by a piped public supply of treated drinking water.

However, storing water may contribute dramatically to water quality deterioration due to stagnation and microbial regrowth (Hashwa \& Tokajian, 2000). Myo et al. (1987) showed that municipal water may be further contaminated when the water is stored in the home. PRWST should be covered to avoid contamination with bird excrement and organic matters coming from the decay of dead insects or animals. Birds may be infected with intestinal pathogens such as Salmonella which may be pathogenic to man (Geldreich, 1996). 
A study conducted in Peru (1992), showed that fecal coliforms counts were 10-times higher in household water storage tanks than in its inlet water, indicating that water was being contaminated further during storage (Swerdlow et al., 1992).

Organic and inorganic suspended particles may protect microorganisms from disinfectants and may provide a suitable substratum for bacterial proliferation which could result in a colonization of the stored water (Schreiber \& Schoenen, 1994).

Since PRWST are widely used and few studies on the microbiological quality have been conducted, the objectives of the present research were to determine the hygienic condition of the PRWST in the city of Jbeil, and to determine the types of microorganisms (mostly bacteria) colonizing them. Chlorination experiments were also held on the water of the black polyethylene and galvanized cast iron household storage tanks in order to monitor the effect of residual chlorine on bacterial population. 


\section{Specific objectives of this study}

- To determine the microbiological quality of water in Byblos (Jbeil) distribution system and in four types of private roof water storage tanks.

- To investigate for the presence of coliforms in the water distribution system and in the PRWST in Byblos.

- To determine the effect of water residence time (storage time) in different household tanks on the microbial diversity and quality of water.

- To compare the effect of water storage on the microbiological quality of the UV treated compared to the chlorinated water in cast iron and polyethylene tanks.

- To determine the effect of the type of the household water storage tanks on the $\mathrm{HPC}$ levels and the microbiological water quality.

- To determine the effect of chlorination on the bacterial distribution in the black polyethylene and the galvanized cast iron household water storage tanks.

- To compare the efficacy of two different conventional bacterial identification systems API and Biolog.

- To determine the hygienic aspects, according to opportunistic and/or pathogenic bacteria, of the chlorinated water stored in the PRWST in Byblos. 


\section{Chapter 2}

\section{LITERATURE REVIEW}

\subsection{Introduction}

In Lebanon, people are more likely to drink ground water that was pumped from artesian wells. In Byblos city, drinking water is supplied to consumers from two different sources. The first source comes from artesian wells located in the city suburb, in Hboub area $4 \mathrm{Km}$ away from the center of city, and the other source located about $40 \mathrm{~km}$ away east of Byblos, from natural spring in Afqa region. The water that comes out of both sources is first subjected to infiltration, and then pumped to reservoirs where it is mixed and chlorinated before immediate release into the network.

Water suppliers use other treatments as needed, according to the quality of their source water. For example, systems whose water is contaminated with organic chemicals can treat their water with activated carbon, which adsorbs or attracts the chemicals dissolved in the water (EPA, 1999).

Numerous factors affect water quality in the distribution system such as pipe materials, diameter, presence of corrosion by-products and biofilm, water temperature, disinfectant residuals, and hydraulic conditions (Baribeau et al., 2001). In order to prevent and control biofilm development, most water utilities chlorinate the treated water. It is also necessary to decrease the dissolved organic carbon as this increases chlorine stability during distribution while also reducing the formation of trihalomethanes (THM) (Gatel et al., 2000). 


\subsection{Groundwater Habitat}

In the 1970 s, it became increasingly obvious that certain waste disposal practices were contaminating subsurface environments with effects on groundwater quality. This led to the current interest in the study of these environments (Madsen \& Ghiorse, 1993).

In a hydrogeological sense, groundwater refers to water that is easily extractable from saturated, highly permeable strata known as aquifers. Underground aquifers that serve as source of potable water in the world can be of three types, shallow aquifers, intermediate and deep aquifers (Maier \& Pepper, 2000).

Shallow aquifers are characterized by active flow (meters per day) strongly influenced by local precipitation events. Intermediate aquifers within $300 \mathrm{~m}$ of the surface soil are separated from shallow aquifers by confining layers; they have much slower flow rates (meters per year).

Deep aquifers are also confined, but more than $300 \mathrm{~m}$ below the subsurface soil and they are characterized by extremely slow flow rates (meters per century). Natural mineral waters originate mainly from intermediate aquifers characterized by a well defined and protected catchments area and a long underground transit time. In this kind of aquifers, often with fine-textured soils, constancy of flow rate, chemical composition and temperature stability, are at all times and under all conditions ensured (Leclerc \& Moreau, 2002).

\subsubsection{Biological component}

The stratified distribution of subsurface microorganisms could have been caused by vertical and horizontal colonization patterns by waterborne soil microorganisms via hydrological flow. It is generally accepted that the majority of bacteria in most ecosystems are attached to surfaces and are not suspended in the aqueous phase, as are planktonic bacteria. The food chain in aquifers is primarily heterotrophic, reliant either upon an influx of dissolved organic carbon (DOC) along a given hydrological flow path or organic compounds of sedimentary origin that subsequently may become degraded. Thus the microbiological investigation of groundwater indicates that heterotrophic bacteria (obtaining their carbon and energy sources from organic compounds) are the dominant 
microorganisms present while eukaryotes might be absent altogether or only present in low numbers (Leclerc \& Moreau, 2002).

The heterotrophic bacteria are capable of growing on simple organic compounds found in culture media such as R2A agar (Reasoner \& Geldreich, 1979), largely used for monitoring drinking water. Because groundwater ecosystems are oligotrophic (deficient nutrition), these bacteria are often termed oligotrophic; in fact many of them are facultative oligotrophic, often capable of adapting to both low and high concentrations of organic substrates.

\subsection{Starvation-Survival Lifestyle}

Due to the long time, the indigenous bacteria have had to degrade the organic matter originally present, subsurface environments contain little organic matter. Furthermore, when percolating through the porous media, water containing organic matter encounters attached bacteria which remove most of this organic matter. Thus, subsurface systems are oligotrophic and the intermediate aquifer flow systems are among the most oligotrophic microbial environments that have ever been described (Morita, 1997).

To confront nutrient limitation, bacteria may develop defense mechanisms to enhance their ability to survive periods of starvation. Some differentiating bacteria respond to starvation by marked alteration in their ultra structure, producing endospores. Endospores are essentially dormant, waiting out lean periods to germinate as nutrients become available. Non-differentiating bacteria respond more by an alteration of their physiology rather than developing resistant structural modifications (Matin, 1992 \& McCann et al., 1992).

\subsubsection{The viable but non-culturable (VBNC) state}

Under certain conditions of metabolic stress such as starvation, bacterial cells may enter a viable but non-culturable (VBNC) state. It has been realized for some time that plate counts can dramatically underestimate the total number of bacteria, determined by acridine orange $(\mathrm{AO})$, present in samples taken from the natural environment. 
A bacterium in the VBNC state is defined by Oliver (1993) as "a cell which can be demonstrated to be metabolically active, while being incapable of undergoing the sustained cellular division required for growth in or on a medium normally supporting growth of that cell". These respiring bacteria that did not have the ability to form colony-forming units (CFU) on agar media might represent the predominant bacterial inhabitants of subsurface habitats. Cells entering the VBNC state generally show a reduction in size as has been noted for cells undergoing starvation.

It has been speculated that the VBNC state represents an additional response to starvation displayed by bacteria for survival (Roszak \& Colwell, 1987) and many bacteria species, including pathogens, have been reported to enter this state under laboratory or field conditions (Oliver, 1993). This state could have important consequences with regard to ecology, epidemiology or pathogenesis, since potentially pathogenic VBNC cells could persist in the environment and regain growth capability and infectivity much later than normal for vegetative cells. The existence of a VBNC state, in response to natural environmental stress, has been observed more often with Gram-negative bacteria representing members of the Enterobacteriaceae, Vibrionaceae including Aeromonas and some genera such as Campylobacter, Helicobacter, and Legionella (Leclerk \& Moreau, 2002).

\subsection{Bacterial Regrowth in Water Distribution Systems}

Regrowth defined as the multiplication of heterotrophic plate count (HPC) bacteria. Many researches have been conducted on the causes of bacterial regrowth in water distribution systems, especially in such cases where there was no evidence of real bacterial contamination by external sources of pollution such as through cross-connections, backsiphonage or infiltration (Sunna-Borgan, 1998). Moreover, Tokajian and Hashwa (2003) concluded that the intermittent mode of water supply in Lebanese distribution systems, associated with changes in pressure, infiltration, line breaks, water stagnation, turbidity, regrowth, non-uniform chlorination and storage in household tanks, were important factors contributing to the deterioration of potable water quality. 
The planktonic growth of bacteria in water and on pipe surfaces, and the recovery of the injured or dormant bacteria that originate from source water are the major mechanisms found to be involved in the increase of bacterial numbers (Volk \& LeChevalier, 1999). During the distribution of drinking water, bacterial regrowth may lead to a deterioration of bacterial water quality, amplification of corrosion, generation of bad tastes and odors, and proliferation of macroinvertebrates (Allen $e$ al. 1980 \& Geldreich, 1996).

\subsubsection{Factors influencing bacterial growth}

Numerous factors affect water quality in the water distribution system such as pipe materials, diameter, presence of corrosion by-products and biofilm, residence time (RT), water temperature, disinfectant residue, and hydraulic conditions. Free and total chlorine concentrations decreased with increasing RT in the distribution system. Pipe size also influenced chlorine decay, especially in warm water; at similar RTs, chlorine concentrations were lowest in small-diameter pipes, greater in the main pipes, and greatest in the batch incubations (Baribeau et al., 2001).

A study conducted by LeChevalier $e t$ al. (1996) screened for the occurrence of coliform bacteria within a distribution system concluded that these bacteria are dependent upon a complex interaction of chemical, physical, operational, and engineering parameters.

\subsubsection{Temperature and seasonal variation}

Fransolet $e$ al. (1985) in a laboratory experiment indicated that temperature caused an increase in the maximum yield of heterotrophic bacteria up to 17.5 times but increasing the temperature further did not cause an increase in the yield.

Carter $e$ al. (2000) showed that bacterial growth rates generally increase with a rise in temperature. Furthermore a significant positive correlation between the water temperature and oligotrophic organisms' counts at the dead- end loop apex distribution network was obtained. They concluded that this is due to a long retention time in the loop $(30 \mathrm{~h}$ on average), so the effect of water temperature on bacterial numbers may have been magnified. 


\subsubsection{Nutrients}

Most of the microbes in drinking water networks are heterotrophic and require organic compounds for their carbon and energy sources. The availability of organic carbon in the form of AOC (Assimilable organic carbon) and phosphorous are considered the key factor to regulate microbial regrowth in drinking water networks (LeChevalier et al., 1987 \& van der Kooij, 1992). A study done by Miettinen $e$ al. (1997) showed that inorganic elements other than phosphorus did not affect much microbial growth in drinking water. Phosphorous was found to be rate limiting for bacterial growth up to a concentration of $10 \mu \mathrm{g}$ of PO4-P per liter.

Natural organic matter (NOM) can be divided into two fractions: biodegradable, and refractory. Microbial occurrence and growth in drinking water are controlled by different disinfection agents such as chlorine, hypochlorite, and ozone. These oxidizing agents have been found to split organic compounds of high molecular weight (NOM) to simple organic acids (BOM), thus increasing the possibilities for growth of heterotrophic microbes in the drinking water network (Daniel $e t$ al., 1993 \& van der Kooij $e$ al., 1989).

Block et al. (1993) recommended an absence of BOM (biodegradable organic matter) after treatment in order to limit bacterial regrowth. In addition to the amount of nutrients, the composition of the BOM is also an important factor for controlling microbial growth. Amino acids are only a small fraction of the natural organic matter, but they represent a high regrowth potential and are highly reactive with chlorine (Gauthier ct al., 1996 \& Hureiki, 1993).

In addition to AOC, BDOC (Biodegradable dissolved organic carbon) and DOC (Dissolved organic carbon) are also produced by disinfection. The AOC and BDOC constitute a small fraction of DOC (0.1-0.9\%). AOC is that portion of biodegradable carbon that can be converted to biomass, whereas BDOC can be mineralized by heterotrophic bacteria (Huck et al., 1992).

Van der Kooij and Hijnen (1995) found that a concentration of 10ug/L AOC in the water was required to control heterotrophic bacterial growth in distribution networks. 
Escobar \& Randall (2001) concluded that it is advisable to measure both AOC and BDOC as indicators of bacterial regrowth potential in distribution systems, and showed that AOC gave the most direct estimation of regrowth potential, while BDOC yielded information on the hydrolysable pool of carbon available for AOCformation.

\subsubsection{Turbidity}

Turbidity in water is caused by the presence of organic and inorganic matter, plankton, and other microscopic organisms. Turbidity can carry nutrients to support microbial growth in the water distribution system. The EPA established a maximum contaminant level (MCL) of turbidity in drinking water. A turbidity of 1 nephelometric unit (NTU) was recommended and up to $5 \mathrm{NTU}$ is allowed if it does not interfere with the maintenance of an effective disinfectant level or interfere with the microbiological quality of water (SunnaBorgan, 1998).

\subsubsection{4 pH}

The bacterial growth in the water distribution systems is crucially dependent on the $\mathrm{pH}$ which is usually in the range of 6 to 8.5 for drinking water but is around 7 for most heterotrophic bacteria in water distribution systems. In addition the $\mathrm{pH}$ can influence the bacterial growth in the water distribution systems by directly affecting the physiological activities of the bacteria, and indirectly by interfering with the disinfectant efficiency in the water (Sunna-Borgan, 1998).

McFeters $e t$ al. (1986) showed that an imbalance in $\mathrm{pH}$ affects the enzymatic activity of microorganism and may lead to coliform injury.

\subsubsection{Pipeline failure}

Pipe characteristics and conditions are also a determining factor in bacterial regrowth. Iron pipe surfaces have been shown to stimulate bacterial growth (Camper, 1995 \& LeChevallier $t$ al., 1993). Moreover, organic matter tends to adsorb to corrosion products on iron pipe surfaces, and the elevated concentration of organic molecules can stimulate bacterial regrowth. 


\subsubsection{Survival of bacteria in drinking water distribution systems}

Drinking water distribution systems are colonized by saprophytic heterotrophic microorganisms such as bacteria, fungi, and yeasts, etc. (Amblard et al, 1996) that grow on biodegradable organic matter (LeChevalier et al., 1991). Potentially pathogenic microorganisms (e.g., Legionella spp.) and microorganisms of fecal origin (e.g., Escheridia $\left.\alpha_{l}\right)$ may also find favorable conditions and proliferate in these systems (Fass $\left.e t a l ., 1996\right)$. Furthermore, coliforms such as Citrobader fremdii, Enterdbader aggomerans, $E$. doacae, and $E$. sakazakï could be also isolated from the network (Tokajian \& Hashwa, 2003).

\subsubsection{Survival of protozoa in drinking water distribution systems}

Amblard $e$ al. (1996) and Servais $e$ al. (1991) have shown that relatively high densities of protozoa are present in almost all water distribution systems and these populations may regulate the autochthonous (present from earliest times) and allochthonous (introduced) bacterial populations. Grazing activity is to be expected in drinking water distribution systems. This means that a fraction of the bacterial biomass produced is removed by protozoa.

\subsubsection{Bacterial growth in biofilms}

In low-nutrient aqueous environments, microorganisms preferentially colonize surfaces rather than grow in the planktonic state. This gives them nutritional advantages and can protect them from adverse environmental influences. Commonly known as biofilm, these layers of bacteria attach to the interior walls of water distribution pipes and to one another increasing the likelihood for waterborne diseases.

Several health threatening waterborne diseases are found in biofilm, including $E$. oli, Legionella pmermphila, Pseudomonas, Flavobacterium, Arthrobacter, Acinetobacter, Sarcina, Micrococcus, Proteus, Bacillus, Klebsiella and Enterobacter. Direct microscopic observations and direct quantitative recovery techniques showed unequivocally that more than $99.9 \%$ of the bacteria grow in biofilms on a wide variety of surfaces (Costerton $e$ al., 1995). 
Field experience shows that a variety of parameters influence biofilm growth. Factors such as water temperature, disinfectant type and residual, selection of the pipe material, corrosion control, and hydraulic conditions may be more influential than the levels of organic matter for regulating the biological activity of the biofilm (Volk \& LeChevalier, 1999).

\subsubsection{Definition of biofilm}

The new definition of a biofilm is a microbially derived sessile community characterized by cells that are irreversibly attached to a substratum or interface or to each other, are embedded in a matrix of extracellular polymeric substances that they have produced, and exhibit an altered phenotype with respect to growth rate and gene transcription (Donlan \& Costerton, 2002).

\subsubsection{Biofilm formation}

Costerton et al. (1995) showed, after subsequent studies with "wild" and fully adherent bacterial strains, that smooth surfaces are colonized as easily as rough surfaces and that the physical characteristics of a surface has a little effect on bacterial adhesion. Once a biofilm has formed and the exopolysaccharide matrix has been secreted by the attached cells, the resultant structure is highly viscoelastic and behaves in a rubbery manner (Stoodley et al., 1998). Donlan and Costerton (2002) stated that when biofilms are formed in low-shear environments, they have a low tensile strength and break easily, but biofilms formed at high shear are remarkably strong and resistant to mechanical breakage (Appendix, fig.182).

How can biofilm affect drinking water?

Health officials frequently cite biofilm as a cause of water contamination. Almost immediately after attaching itself to pipeline walls, biofilm begins building upon itself, adding layer upon layer, forming a plaque-like coating. The bacterial community traps nutrients, microbes, worms and viruses to form an almost impenetrable material. Such growth can clog water lines to the point of insufficient water pressure (Appendix, fig. 3). In addition, biofilm contributes to reduced heat transfer, further pipe corrosion and depletion of the chlorine used to protect drinking water from the treatment plant to the tap (Reiff, 1996). 


\subsubsection{Remedies used to remove biofilm from pipelines}

Chlorinating the drinking water supply is the method usually used to control biofilm growth. In most cases, maintaining the normal amount of chlorine used to disinfect drinking water will control this problem. However, some water distribution systems have required special cleaning efforts, such as super chlorination and/or high-velocity flushing on an intermittent basis. Depending on the amount of biofilm, water suppliers may increase chlorine levels for a week or so. Without proper maintenance, the ability of biofilm to form the plaque-like coating mentioned above, can at times only be removed by costly scouring with mechanical devices, often referred to as "pigging" (Reiff, 1996).

\subsection{Public Health Aspects: Water-Borne Infections}

The epidemiological history of waterborne diseases after the 1970 s is marked by the emergence of enteric viruses and protozoans. Many of them are resistant to conventional chlorination and have thus been involved in waterborne outbreaks. Other new pathogens include species of environmental bacteria that are capable of growing in water supply networks, such as Legionella spp., Flawbacteria spp., Aeromonas spp., Myobaderim spp. and Psendomonas aenuginosa. These new epidemiological data have questioned the ability of conventional treatment to provide a safe supply of water and the use of marker organisms such as coliforms to monitor the efficiency of water treatment (Leclerc \& Moreau, 2002).

\subsubsection{Water-bome pathogens}

There is a Variety of environmental opportunistic human pathogens that can pass through water treatment barriers at very low densities and take advantage of selected sites in the water supply systems to colonize. They are typical biofilm organisms that grow at the periphery of distribution systems (long pipes leading to dead ends) and throughout the pipe network where the water can be stagnant. The most important organisms to consider are P. aenuginosa, Aeromonas, Legionella and Mycobacterium complex (Szewzyk et al., 2000). 


\subsubsection{Pseudomonas aeruginosa}

Fluorescent Psendomonas strains constitute a diverse group of bacteria that can be visually distinguished from other Pseudomonads by their ability to produce a water soluble yellowgreen pigment (Dabboussi et al., 1999).

P. aemuginosa is a ubiquitous environmental bacterium. It is an opportunistic pathogen that can cause community- or hospital- acquired (nosocomial) infections. Since $P$. aemuginosa is capable of growing in oligotrophic waters for extended periods of time, and it has major opportunistic pathogen capability, its occurrence in natural mineral water should be limited as far as possible (Hardalo \& Edberg, 1997). It can be isolated, often in high numbers, in common food, especially vegetables. $P$. denuginosa may also be derived from human or animal excrement, but its presence in feces is not universal. Because of this and its ability to multiply in water containing suitable nutrients it cannot be used as an indicator of fecal pollution (HMSO, 1994).

\subsubsection{Burkholderia cepacia}

Of importance to mention in this study Bunkbolderia cepacia (formerly P. copacia) is a common environmental bacterium which can be pathogenic for plants and humans. Bunkbolderia copacia complex is a very diverse group of bacteria (Vandamme et al., 1997). They are important opportunistic human pathogens that cause devastating infections in patients with cystic fibrosis (CF) (Govan \& Deretic, 1996) and in other vulnerable individuals (Speert $e t$ al., 1994). This organism is also able to survive on or in medical devices and disinfectants. Alternatively, person-to-person transmission also has been documented (Gilligan, 1991).The ability of B. copacia to cause disease is not limited to the human host, as these bacteria are also important plant pathogens (Gonzalez et al., 1997). In addition, B. cepacia complex bacteria may have commercially useful properties and have been used in agriculture as biocontrol agents and in the bioremediation of toxic agents (LiPuma \& Mahenthiralingam, 1999).

Bacteria of the $B$. copacia complex consist of five discrete genomic species, including genomovars I \& III and three new species: B. multizorans (formerly genomovar II), B. stabilis (formerly genomovar IV) \& B. vienamiersis (formerly genomovar V). Strains of all 
five genomovars are capable of causing opportunistic human infection, and microbiological identification of these closely related species is difficult (Mahenthiralingham et al., 2000).

\subsubsection{Aeromonas spp. (A. hydrophila)}

Aeromonas are widespread in surface waters. Their presence in sediment accumulated in pipelines in the water supply is an indication of biofim development. Aeromonas spp. are sometimes able to contaminate mineral water in low numbers for the same reason as coliforms or $P$. aeniginosa. Their significance is the same as that of quality indicators. The growth potential of $A$. bydrophila in drinking water, also with low concentrations of organic compounds, is well established. Several investigations have shown a high incidence of A eromonas spp. in municipal drinking water supplies (Clark $a$ al, 1982). It was shown that A eromonas spp. can survive standard chlorination and thus recolonize the water cistribution networks after the chlorination process (van der Kooij, 1992).

A eromonas spp. can cause gastroenteritis, wound infections, bacteremia, and miscellaneous other infections including endocarditis, meningitis, pneumonia, conjunctivitis, and osteomyelitis. A greater risk of infection is reported in young children, elderly people, and immunocompromised patients (Janda, 1991). Aeromonas bydrophila has been increasingly recognized as an enteric pathogen and has been associated with a wide variety of human infections. The enteropathogenicity of A eromonas spp. has been ascribed to the production of exotoxins (Cahill, 1990). It has been reported that $A$. cariae and $A$. solria may cause enteritis (Janda $a$ al., 1996). A. sobubertï, $A$. jandaei and $A$. zeronï biotype zeronï are also potentially pathogenic species for humans and may occur in water (Janda \& Abbott, 1998).

\subsubsection{Legionella pneumophila}

The genus Legionella was established in 1979 after a large outbreak of pneumonia among members of the American Legion and was traced to a previously unrecognized bacterium, Legiondla preumophila (McDade at al., 1977). L. pmenmophila is a gram-negative bacterium, fastidious and not easily detected which multiplies at temperatures between 25 and $42^{\circ} \mathrm{C}$, with an optimal growth temperature of $35^{\circ} \mathrm{C}$ (Katz \& Hammel, 1987). 
This environmental bacterium inhabits fresh waters, where it parasitizes intracellularly within free living protozoa and uses a similar mechanism to multiply within mammalian cells (within macrophages) (Abu Kwaik et al, 1998 \& Fields, 1996). Upon transfer from natural aquatic habitats into drinking water systems Legionella can impose life threatening health risks. Warm water systems provide an ideal habitat for massive growth of the bacterium (Sanden et al., 1989).

The pathogenesis of Legionnaires' disease is largely due to the ability of $L$. pmemmopbila to invade and grow within macrophages (Steinert et al., 2002) (Appendix fig. 4).

Upon aerosol formation via man-made water systems, $L$. preumpobila can enter the human lung and cause a severe form of pneumonia, called Legionnaires' disease. L. premmphila is being an important cause (5-15\%) of community-acquired and of hospital-acquired pneumonia. The occurrence of Legionella within biofilms and its ability to enter a VBNC state contribute to its survival (Atlas, 1999).

\subsubsection{Mycobacteria}

Environmental mycobacteria, which are also called atypical mycobacteria or nontuberculous mycobacteria (NTM), are common saprophytes in all natural ecosystems, including water, soil, food, dust, and aerosols (Covert et dl., 1999).

Collins et al. (1984) showed that NTM can colonize, survive, persist, grow, and multiply in tap water, and have been isolated from public water distribution systems and from samples from various other sources, including hot and cold water taps, and ice machines.

It has been shown recently that the numbers and frequencies of recovery of $M$. ariumand M. intracellulare from drinking water are usually low (Falkinham et al., 2001). The occurrence of non-tuberculous mycobacteria such as $M$. azium, $M$. kansasii or $M$. intracellulave has never been reported for mineral water samples (Covert et al., 1999).

The saprophytic mycobacteria identified in drinking water were $M$. gordonae, $M$. nondromgeriaum, $M$. flanescers, and $M$. drualii, whereas the potentially pathogenic mycobacteria were M. penegrimum, M. fortutum, and M. chelonae (LeDantec et al., 2002). 
Mycobacteria are not killed by common disinfectants and can tolerate wide ranges of $\mathrm{pHs}$ and temperatures, which allows them to persist in drinking water systems and in biofilms on the insides of pipes and taps for long periods of time (Falkinham, 1996).

\subsubsection{Outbreaks of water-borne infections}

The possibility that an outbreak of water-borne infection may result from operational problems such as failure of disinfection, filter breakdown, "Ultraviolet lamp deterioration" or a major pollution incident causing damage to some part of the distribution system. It was stated that defects in plumbing, cross-connections, back flow and pressure fluctuations can cause contamination of distribution systems, and can result in the transmission of organisms causing infection.

\subsection{Microbiological Examination of Drinking Water: Rationale}

Full examination of a water supply embodies several lines of investigation including topographical, chemical, biological and microbiological characterization. Bacteriological examination is particularly important because it remains the most sensitive method of detecting fecal and therefore potentially dangerous poilution. Monitoring for microbiological contamination is necessary to determine the sanitary quality of drinking water. The numbers and types of disease causing organisms (pathogens) are so large and varied that testing for all of them is too costly, therefore a single group of bacteria, called the coliform group, is used as an indicator of the potential presence of pathogens.

\subsubsection{Indicator organisms}

This concept of indicator organisms was introduced in 1892 and is the basis for most microbiological quality standards in water today (Schardinger, 1967). Coliforms are also routinely found in diversified natural environments, as some of them are of telluric origin (from earth), but drinking water is not a natural environment for them. Their presence in drinking water must at least be considered as a possible threat or indicative of microbiological water quality deterioration (Rompréa et al., 2002). Organisms that fit these criteria include the coliform bacteria, fecal streptococci (enterococci) and the sulfitereducing clostridia (i.e., Clostridium peffringers). Gastrointestinal pathogens known to have 
caused outbreaks of enteric disease are largely from the systematically defined family, Enterobacteriaceae, and include Salmandla, Shigella, Yersinia enterocditica, klebsiella pmamomia, Enterobacter and enterotoxigenic Esdheridhia $\alpha d i(E . \alpha)$. Vibrio doderae and Camplobacter jeinui are two other enteric pathogens often found in contaminated water (Krieg, 1984). These organisms are spread by water contaminated with fecal material from humans and other warm-blooded animals.

\subsubsection{Coliforms}

The coliform group includes a broad diversity in terms of genus and species, whether or not they belong to the Enterobacteriaceae family. In Standard Methods for the Examination of Water and Wastewater (APHA at al., 1998), coliform group members are described as:

1. all aerobic and facultative anaerobic, Gram-negative, non-spore-forming, rod-shaped bacteria that ferment lactose with gas and acid formation within $48 \mathrm{~h}$ at $35^{\circ} \mathrm{C}$ or

2. all aerobic and many facultative anaerobic, Gram-negative, non-spore-forming, rodshaped bacteria that develop a red colony with a metallic sheen within $24 \mathrm{~h}$ at $35^{\circ} \mathrm{C}$ on an Endo-type medium containing lactose.

The definition of members of the coliform group has recently been extended to include other characteristics, such as --galactosidase- positive reactions (APHA $a t$ al., 1998). The cytochrome-oxidase test is also used as a confirmation test to eliminate some bacteria of the Aeromonas or Pseudomonas genera that would ferment lactose.

As an indicator group, the number of viable coliform organisms present does not always correlate properly with the presence of pollution. Elevated total coliform counts can occur from the presence of Klebsiella, Citrobacter, and other organisms of non-fecal origin that do not necessarily reflect the health risks associated with consumption of the water ( Hach, 2000). 


\subsubsection{Total coliform}

The United States Environmental Protection Agency (EPA) has determined that the presence of total coliforms is a possible health concern. Total Coliforms are common in the environment and are generally not harmful themselves. Positive total coliform samples in treated water which is usually coliform-free may indicate treatment ineffectiveness, loss of disinfectant, breakthrough (McFeters $e$ al., 1986), intrusion of contaminated water into the potable water supply (Geldreich $e t$ al., 1992) or regrowth problems (LeChevallier, 1990) in the distribution system, and, as a consequence, should not be tolerated.

According to the WHO total coliform counts should be 0 per $100 \mathrm{~mL}$ in piped, treated water supplies with an occasional occurrence of two organisms per $100 \mathrm{~mL}$ being allowed. In unpiped water supplies, total coliform counts of 10 organisms per $100 \mathrm{~mL}$ can occur infrequently (WHO, 1984).

\subsubsection{Fecal coliforms/E. coli}

The United States Environmental Protection Agency (USEPA) has determined that the presence of fecal coliforms or specifically $E$. oli is generally not harmful themselves, but their presence in drinking water is serious because they are usually associated with sewage or animal wastes. No $E$. coli are therefore allowed in drinking water. Nowadays the accepted definition of fecal coliform bacteria is: thermotolerant total coliform bacteria capable of growth with acid and gas production at $44.5 \pm 0.2{ }^{\circ} \mathrm{C}$. The bacteria included in this group are predominantly E. coli, Citrobater fremalii and Klebsiella pmeumorniae (Appendix fig. 5).

Escheridia coli is the predominant facultative anaerobe of the human colonic flora. The organism typically colonizes the infant gastrointestinal tract within hours of life, and, thereafter, $E$. ooli and the host derive mutual benefit (Drasar \& Hill, 1974). E. coli usually remains harmlessly confined to the intestinal lumen; however, in the debilitated or inmunosuppressed host, or when gastrointestinal barriers are violated, even normal "nonpathogenic" strains of $E$. coli can cause infection (Nataro \& Kaper, 1998). 


\subsubsection{3.a E. coli $\mathrm{O} 157: \mathrm{H7}$ pathogenesis}

Viable $E$. codi O157:H7 have the capacity to leach through soil and can thus contaminate groundwater and private drinking water supplies (Jackson et al., 1998). The most important factors for long-term survival of $E$. coli $\mathrm{O} 157: \mathrm{H} 7$ in private drinking water thus appear to be absence of protozoan grazer populations and low concentrations of heavy metals.

E. coli $\mathrm{O} 157: \mathrm{HZ}$ is a human pathogen with a very low infectious dose, around 100 cells (Szewzyk et al., 2000), which can cause severe and sometimes fatal illnesses such as hemorrhagic colitis and hemolytic uremic syndrome (Coia, 1998 \& Jones, 1999).

\subsubsection{Coliforms in drinking water}

Monitoring for microbiological contamination is necessary to determine the sanitary quality of drinking water. The natural habitat of enteric bacteria is the intestine of humans and animals. When discharged into a natural aquatic system, these allochthonous microorganisms need to adapt for survival in this hostile environment. Nutrient starvation in the oligotrophic nature of water systems is a major factor that negatively affects survival of coliform bacteria.

\subsubsection{Survival of coliforms in water}

In a study done by McFeters et al. (1986) the comparative survival of organisms in well water indicated that coliform bacteria have a half-life of 17 hours whereas the pathogenic Salmonella typhi have a half-life of 6 hours and Vibrio doderae have a half-life of 7.2 hours. Data confirm the effectiveness of coliforms as indicators of the absence of these pathogenic organisms. However, other pathogenic Salmonella and Shigella organisms have half lives in the range of 16 to 27 hours.

\subsubsection{Opportunistic organisms (require few nutrients to grow)}

Species of the family Enterobacteriaceae are usually opportunistic organisms not normally associated with diarrheal disease in healthy hosts (Krieg, 1984). These organisms are harmless in healthy hosts but are pathogenic in compromised hosts (for example, malnourished, diabetic, or immunosuppressed patients). 
E.coli, Kldbsiella, Enterdbacter, Proteus, Providencia, and Serratia mancescens, of the Enterobacteriaceae family, are responsible for $50 \%$ of the hospital-related infections in the United States. Of importance in this study Citrobater spp. and Enterdacter spp. which are considered to be opportunistic pathogens caused a wide variety of nosocomial infections of respiratory tract, urinary tract, blood, and other normally sterile sites (Benenson, 1995).

Potable and bathing waters containing excessive numbers of other opportunistic organisms such as Psendomonas, Flawdacterium and Acinetobacter may produce infection in compromised hosts also (HMSO, 1994).

Opportunistic organisms flourish in the pipes when disinfection levels injure, rather than kill, organisms in drinking water treatment plants and when residual disinfectant levels are inadequate in distribution systems. Regrowth of these organisms in distribution systems has become a major problem. Coliform counts cannot be used to predict the existence of many of these bacteria. For example, $P$. aeruginosa, often occurring in human feces in much lower numbers than coliform organisms, frequently are found in untreated water in the presence of coliforms. However, in drinking water they may occur in the absence of routinely detectable coliforms (Reitler et al., 1957 \& Nemedi $a$ al., 1971).

Several noncoliform bacteria, including $P$. aenuginosa, Bumkbolderia cepacia, Serratia mancescens, A cinctobater calocactious, Flawbacterium meningoseptiom, A eromonas bydrophila, and certain nontuberculous mycobacteria, can replicate in relatively pure water (Millership \& Chattopadhyay, 1985). These organisms may be present in drinking water that has acceptable levels of coliform bacteria (i.e., 1 coliform bacterium $/ 100 \mathrm{~mL}$ ).

\subsection{Heterotrophic Bacteria Isolated from Drinking Water}

Analyses for heterotrophic plate count ( $\mathrm{HPC}$ ) bacteria in water distribution systems can be helpful in assessing water quality. These measures are useful in determining changes in water quality both during storage and distribution (Carter et al., 2000). In certain epidemiological studies reported by Payment $\ell$ al. (1991), there is a debate on the potential negative impact to human health from the consumption of treated water containing high 
HPC levels of bacteria. To date, there has been no association between human disease and the natural bacteria found in natural mineral water.

Levels of HPC bacteria may also be used to assess microbial growth on materials used in water distribution systems and for measuring bacterial after regrowth in distributed water. Phenotypic characteristics of HPC bacteria may be useful in defining water quality. Orange and yellow pigmented bacteria were the dominant expressions in all bulk fluid and biofilm samples yet small numbers of pink and red bacteria were also found. Pigmented bacteria are considered potentially useful markers for interpreting changes in the microbiological quality of finished water. Although pigmented bacteria generally go unnoticed due to their slow growth, they can be detected on R2A agar (an extremely lownutrient agar) using a 7-day incubation period (Geldreich, 1996). In addition, Reasoner $e t$ al. (1989) found large numbers of pigmented bacteria in dead-end regions of a distribution system. The largest numbers were found in the absence of free chlorine and at a water temperature greater than $16^{\circ} \mathrm{C}$.

Reasoner \& Geldreich (1985) suggested that the low nutrient R2A agar was a better choice for development of the HPC bacteria isolated from drinking water. The spread plate procedure, using R2A agar, was advocated for the recovery of oligotrophic organisms. When using R2A agar, all water samples should be incubated for not less than 72 hours and up to five to seven days at $35^{\circ} \mathrm{C}$ or a minimum of five and preferable seven days at 20 or $28^{\circ} \mathrm{C}$ (Hach, 2000). In a study performed by Geldreich (1996) concerning treated distribution water, showed that incubation at $20^{\circ} \mathrm{C}$ yielded the highest counts on all media when incubation was extended to 12-14 days, whereas $28^{\circ} \mathrm{C}$ appeared to be the best temperature from day 2 through day 6 of incubation. 


\subsection{Uses of Inorganic Hypochlorite (Bleach) in Water Treatment}

\subsubsection{Definition}

Chlorination of drinking water has been introduced to the water supply since the beginning of the 19th century in order to stop the spreading of pathogens especially typhoid fever by drinking water (Schoenen, 2002).

At the present time it is stated that chlorination and filtration of raw water are responsible for the virtual elimination of serious waterborne diseases such as cholera, typhoid, dysentery and hepatitis A (White, 1986).

\subsubsection{Characteristics of the ideal disinfectant}

Oxidizing disinfectants such as chlorine, chloramines, and ozone are the most commonly used disinfectants for drinking water. A large number of antimicrobially active chlorine compounds are commercially available. These include sodium and calcium hypochlorites, liquid chlorine, chlorine dioxide, and inorganic and organic chloramines (Dychdala, 1991 \& Russell, 1990).

Hypochlorite has held a predominant position as a reliable disinfectant because it has many of the properties of the ideal disinfectant, which include a broad antimicrobial spectrum, rapid bactericidal action, reasonable persistence in treated potable water, ease of use, solubility in water, relative stability both in its concentrated and dituted form, relative nontoxicity to humans at use concentrations, lack of poisonous residuals (reduced predominantly to chloride as a result of its oxidizing action of inorganic and organic compounds), action as a deodorizer, colorless, nonflammable, non staining, and low cost (Rutala \& weber, 1995). However, when chlorine reacts with naturally occurring organic matter in water-such as humic and fulvic acids-chlorination by-products (CBPs) are generated (Rook, 1974 \& Symons a al., 1975). Among CBPs found in chlorinated water, trihatomethanes (THMs) and haloacetic acids (HAAs) have been the focus of particular attention because they are considered potentially carcinogenic (McGeehin $t$ t al., 1993). Also, recent studies have suggested links between adverse reproductive outcomes and exposure to CBPs during pregnancy (King \& Marret, 1996; Dodds et al., 1999).

THMs include chloroform, dichlorobromomethane (DCBM), dibromochloromethane (DBCM) and bromoform (Sérodes et al., 2003). Wheras, haloacetic acids (HAA) include 
nine substances but the most common are monochloroacetic acid (MCAA), dichloroacetic acid (DCAA), trichloroacetic acid (TCAA), monobromoacetic acid (MBAA), dibromoacetic acid (DBAA) and bromochloroacetic acid (BCAA) (Pontius, 1995).

Recently, the United States Environmental Protection Agency (US-EPA) promulgated the Stage 1 and 2 disinfectant/disinfection by-products (D/DBPs) rule to cope with some of these harmful DBPs in drinking water (Pontius, 1999). The MCLs (Maximum Contaminant Levels) under the Stage 1 D/DBP rule promulgated in 1998 include THMs $0.080 \mathrm{mg} / \mathrm{L}$, sum total of five HAA concentrations $0.060 \mathrm{mg} / \mathrm{L}$, with the maximum residual disinfectant concentration over chlorine $4.0 \mathrm{mg} / \mathrm{L}$ (Yoon $e t a l ., 2003$ ).

\subsubsection{Chlorine compounds with antimicrobial activity}

A variety of commercial products used in the home and health-care facilities contain 1 to $15 \%$ sodium hypochlorite. In the literature, $\mathrm{HOCl}$ and/or the $\mathrm{OCl}_{2}$ in aqueous solutions is referred to as either "free residual chlorine" or as "free available chlorine." Once these compounds are reacted with ammonia or $\mathrm{N}$-organo compounds to form a series of loweroxidation potential compounds such as monochloramine $\left(\mathrm{NH}_{2} \mathrm{Cl}\right)$, dichloramine $\left(\mathrm{NHC}_{2}\right)$, or a variety of organo-N-chloro compounds, the term applied is either combined chlorine, combined residual chlorine, or combined available chlorine (Ellis, 1991).

Researchers have demonstrated inferior microbial inactivation with combined available chlorine compounds compared with products producing free available chlorine. For example, it takes approximately 25 times as much chloramine as free available chlorine to effect a rapid bactericidal action. In addition, it is proved that monochloramine is a weaker disinfectant than free chlorine for many waterborne pathogens, since the contact time (CI) value for monochloramine is 2 -fold to 3 -fold greater than for free chlorine (Hach, 2000). Gurrently, inorganic chloramines are being used for chlorination of some water supplies to prevent trihalomethane formation. However, in a study done by Najm \& Trussell in 2001 showed that nitrosodimethylamine (NDMA), a probable human carcinogen, is a likely by-product of chloramination of drinking water and wastewater and that NDMA formation increases with increasing chloramines dose. In addition, the same study showed that several ion exchange resins can leach NDMA into drinking water, especially those water providers using strong-base anion exchange resins for inorganics removal. 


\subsubsection{Objectives of water treatment}

The objective of water treatment is to produce final water which is microbiologically and chemically safe for consumption, not corrosive towards materials in contact with water and aesthetically acceptable (HMSO, 1994). When chlorine is used for water disinfection the dose should be so selected that the chemical demand of the water is satisfied and that an adequate contact time is achieved before water is distributed to any consumers. Residual chlorine of $0.5 \mathrm{mg} / \mathrm{L}$ should be maintained throughout the distribution system and should preferably be present in water at consumers' tap, to reduce the risk of microbial regrowth and to provide an indication of the absence of post-treatment contamination (Tokajian, 2002).

\subsubsection{In vitro efficacy}

Sodium hypochlorite has broad antimicrobial activity. Generally, viruses and vegetative bacteria are more susceptible to hypochlorites than are endospore-forming bacteria, fungi, and protozoa. This selective resistance of organisms to hypochlorite may be compensated for either by increasing the concentration, by lowering the $\mathrm{pH}$, or by raising the temperature. Many factors affect the stability of free avaitable chlorine in solution and the efficacy of its antimicrobial activity. These include chlorine concentration, presence and concentration of heavy metal ions, $\mathrm{pH}$ of the solution, temperature of the solution, presence of a biofilm, presence of organic material, and UV irradiation (Rutala, 1996).

\subsubsection{Disinfection of potable water}

Disinfection with chlorine has been the single most important process for ensuring the microbiologic safety of potable water supplies. Since the beginning of routine chlorination of water supplies, waterborne outbreaks of infectious agents have been exceedingly rare. Most waterborne outbreaks are believed to be due to the use of untreated water, systems receiving inadequate treatment, or contamination after treatment (Bull $e t$ al, 1990).

A review of in vitro studies of inactivation of human pathogenic bacteria transmitted by potable water reported that 0.1 to $1.0 \mathrm{ppm}$ free chlorine inactivated $(99 \%$ kill) all pathogenic vegetative bacteria within $60 \mathrm{~min}$ with the exception of some nontuberculous mycobacteria (Sobsey, 1989). Nontuberculous mycobacteria are relatively resistant to the 
levels of chlorine found in potable water. In one study with $M$. dedomei and $M$. fortuitum, survival at $60 \mathrm{~min}$ was noted for $60 \%$ of mycobacteria exposed to $0.3 \mathrm{ppm}$ chlorine and for $2 \%$ of mycobacteria exposed to $0.7 \mathrm{ppm}$ (Carson $e t$ al., 1978). This finding provides an explanation of why small numbers of nontuberculous mycobacteria may be isolated from adequately chlorinated hospital water supplies.

On the other hand Sobsey (1989) reported that all viruses tested in saline were inactivated (99.9\%) within $10 \mathrm{~min}$ by 0.1 to $0.5 \mathrm{ppm}$ chiorine and that protozoan cysts (Giardia, Acanthamoeba, \& Naeglenia spp.) were significantly reduced ( $90 \%$ ) by 1 to $4 \mathrm{ppm}$ chiorine.

\subsubsection{Mechanism of action}

Chlorine in the form of hypochlorous acid, even in minute quantities exhibits rapid microbicidal activity (Dychdala, 1991). The inhibitory or lethal activity depends on the amount of free available chlorine in the solution (in the form of hypochlorous acid, HOC, present in bleach and chlorine solutions) that comes in contact with microbial cells. Free chtorine disinfects by chemically disrupting bacterial cell walls and membranes through oxidation of a chemical group known as the thiol group (WHO, 1998).

Helicobacter pylori is moxe resistant than $E$. coli to chlorine and ozone but not monochloramine. H. pylori may be able to tolerate disinfectants in distribution systems and, therefore, may be transmitted by a waterborne route (Baker et al., 2002).

Disinfection efficiency is controlled by the concentration of disinfectant $(C)$ measured in $\mathrm{mg} / \mathrm{L}$ and contact time (T) determined in minutes to achieve a $6 \log$ reduction of bacteria, $4 \mathrm{log}$ reduction in virtses, and $3 \mathrm{log}$ reduction in protozoa (Geldreich, 1996).

The measurement of chlorine concentration in a water source is of little significance as an indicator of health risk if the factors of $\mathrm{pH}$ and contact time are not known. Turbidity of the water source may also affect the bactericidal activity of the halogen.

\subsubsection{Effect of $\mathrm{pH}$ on bactericidal activity}

Hypochlorites are salts of the hypochlorite ion $\left(\mathrm{OC}_{2}\right)$. The sodium salt produces an aqueous solution, while the calcium salt is a solid. The active species is undissociated hypochiorous acid (HOC), not chlorine. The dissociation of hypochlorous acid to the less 
microbicidal form (hypochlorite ion) is dependent on $\mathrm{pH}$. As the $\mathrm{pH}$ increases, more hypochlorite ion is formed and the microbicidal activity decreases (Hoffman et al., 1981). The concentration of the fast-acting, antimicrobial hypochlorous acid, the chemical species providing free available chlorine to disinfectant solutions, is a function of $\mathrm{pH}$ Between $\mathrm{pH}$ 6.5 and $7.0, \mathrm{HOCl}$ exists as $80-95 \%$ of the free chlorine concentration. At $\mathrm{pH}$ greater than 8 , the free chlorine concentration is less than $20 \%$ (Appendix, fig. 6).

Therefore, to maintain a given free chlorine concentration, it is necessary to monitor and adjust the pH (between 5 and 7 ) of disinfectant solutions (Suslow, 2000). Thus, research has shown that hypochlorous acid is 80 times more effective than the hypochlorite ion in the inactivation of $E$. coli and 150 times more effective for cysts of Entamoeba bistobtica (White, 1972). The microbiocidal properties of hypochlorous acid probably can be attributed to its ability to penetrate cell walls. The ease of penetration is due to the low molecular weight and electrical neutrality of hypochlorous acid. The negatively charged hypochlorite ion is unable to diffuse through cell walls and is, therefore, a very poor disinfectant (White, 1978).

\subsubsection{Effect of interfering substances}

Particulate matter in water (turbidity) creates physical interferences which may decrease the effectiveness of chlorination. Turbidity may be caused by either inorganic or organic particles; however, inorganic particles appear to be of little consequence. The hardness of the water (i.e., the presence of $\mathrm{Mg}^{2+}$ and $\mathrm{Ca}^{2+}$ ions) does not have a significant effect on the antibacterial action of hypochlorite solutions. Various chemical substances, such as organic and inorganic forms of nitrogen, hydrogen sulfide, iron, and manganese, react with chlorine in water, consuming the chemical and rendering it ineffective as a bactericide. This creates what is called a chlorine demand in water. The effective concentration of chlorine required to disinfect water is the chlorine demand plus the necessary germicidal concentration (Hach, 2000).

LeChevallier et al. (1996) showed that a chiorine dose of $5 \mathrm{mg} / \mathrm{I}$ with one hour of contact time resulted in a $99.5 \%$ reduction in coliforms in waters with a turbidity of 5 NTU. However, under the similar conditions but with turbidities of 8 to 13 NTU, the reduction was only 20\%. Day et al. (1997) \& Korshin et al. (1997) showed that Sphingomonas bacteria 
attached to goethite particles in drinking water that survived the chlorination were mainly forming bacterial aggregates. So an apparent chlorine demand in such particles could result from their becoming coated with dissolved organic matter, since organic compounds are easily trapped at the surface of goethite particles.

Furthermore, Lisle et al. (1998) stated that bacterial starvation in the distribution systems is one of the most important factors that influence the sensitivity of bacteria to disinfectants. The consensus is that the resistance of starved bacteria to chlorine is primarily due to limited chlorine transfer to intracellular target bacteria because of changes in the cell membrane permeability, accumulation of exopolymers on the bacterial cell surface (Rudd et al., 1982), and/or formation of aggregates (Gauthier et al., 1999).

The presence of a biofilm, as might be found in pipes carrying potable water significantly reduces the efficacy of hypochlorites. For example, LeChevalier et al. (1987) reported that a biofilm of bacteria grown on a variety of surfaces were 150 to 3,000 times more resistant to hypochlorous acid than were the unattached or the planktonic cells.

\subsubsection{Contact time}

The time required for chlorine to disinfect a water source is dependent (inversely proportional) upon the concentration of the chlorine, $\mathrm{pH}$, temperature, and turbidity of the water. A useful relationship for determining the disinfection requirement is the $C T$, defined as the effective concentration of chlorine in $\mathrm{mg} / \mathrm{L}$ multiplied by the contact time ( $T$, the time in minutes between dosing and usage). Then the dose of chlorine required for disinfection is determined by selecting the limiting $C T$ parameter- and applying that value $C T$ to the equation: Dosage $=(C T / T)+$ chlorine demand. This inversely proportional relationship indicates that a lower $\left[\mathrm{C}_{2}\right]$ may be used as the initial dose if the contact time is longer, or if the contact time is very short high dose of chlorine must be used.

\subsubsection{Temperature}

The CT relationship is inversely proportional to the water temperature. Thus, as the temperature increases, the chlorine dosage required to inactivate the microorganisms decrease. The temperature relationship may be invalid for thermophilic bacteria (Lippy, 1986). 


\section{MATERIALS AND ME'THODS}

\subsection{Introduction}

Due to the water shortage in Jbeil (Byblos), especially in the summer season, where the water is supplied to consumers in rations three times a week, all householders store water in private roof water storage tanks (PRWST, generally not for drinking purposes).

The residential area studied, which is fed by gravity, had a population of about 4000 , is supplied with drinking water from artesian wells located $4 \mathrm{Km}$ away from consumers. Chlorination of the drinking water during the experimental period was performed regularly by technicians of "Byblos Water Company".

Storage of treated drinking water is essential for people to meet their daily water demand and to provide water at times of no flow. Most of the household water storage tanks in Lebanon are of two types ${ }^{\ddagger}$ cast iron and polyethylene. Whereas other types such as Eternite (with asbestos fibers) and fiber glass tanks are less frequent. Tanks are ustally elevated on the roofs of buildings, placed underground or installed at ground levels.

The Byblos water company, which is under the supervision of the Ministry of Water and Electricity Resources, is by law the responsible body for supplying potable drinking water that is expected to meet the international water quality standards in Byblos district. However, the house-hold tank water quality is considered to be a private responsibility and therefore not controlled by any municipal or governmental authority. 


\subsection{Description of the First Study}

\subsubsection{Private roof water storage tanks (PRWST)}

In order to examine the effect of the house-hold water storage on bacterial growth, a controlled experiment was conducted in the city of Byblos. Drinking water coming through the distribution system was stored on the roof of a private building, located in the city center, in four kinds of house-hold water storage tanks: Fiber glass, cast iron, asbestos and black polyethylene (Fig. 1 \&2).

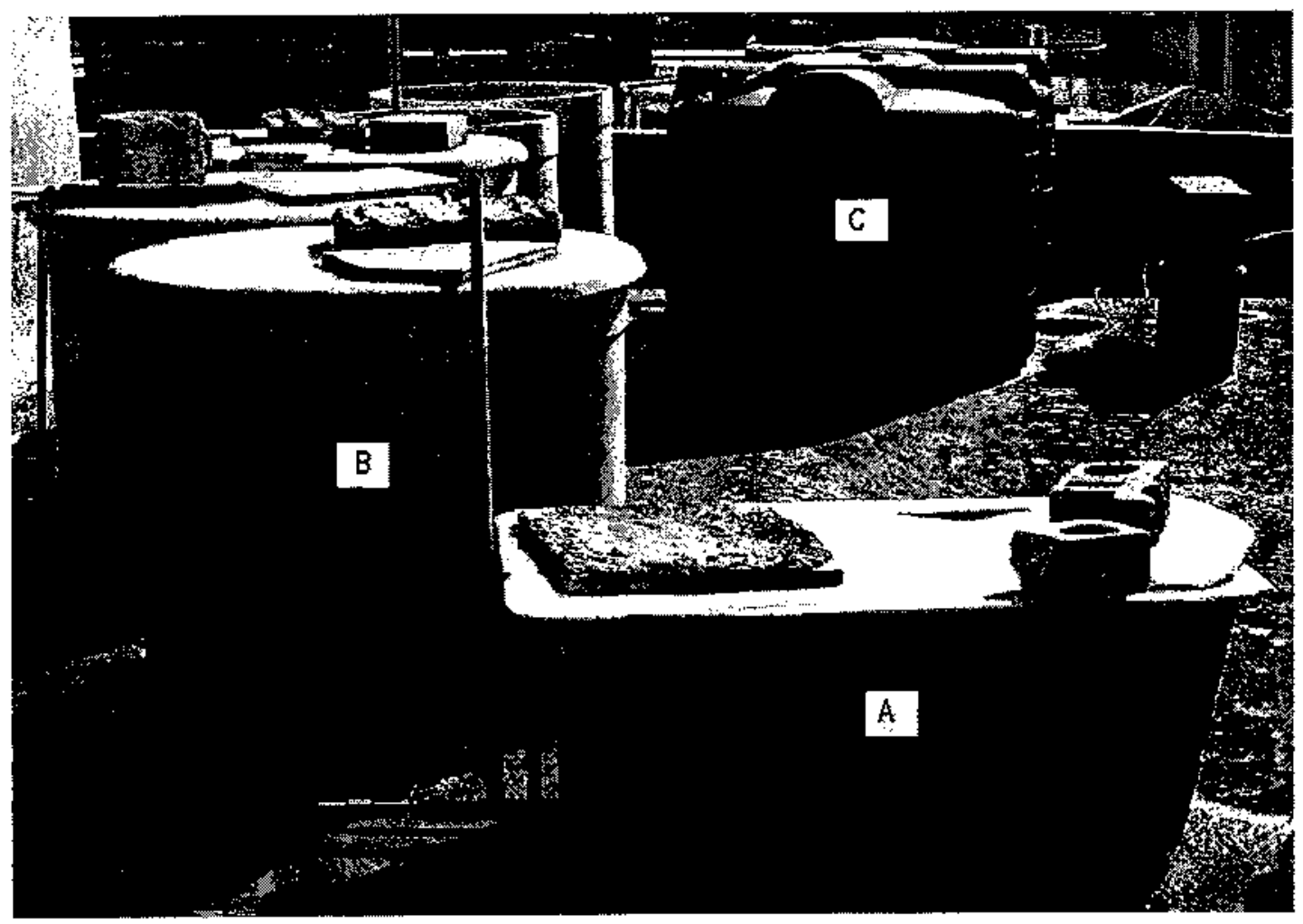

Figure 1: Fiberglass (A), eternite (Asbestos) (B), and the polyethylene (C). (Tanks installed on the roof top of a building in Byblos city). 


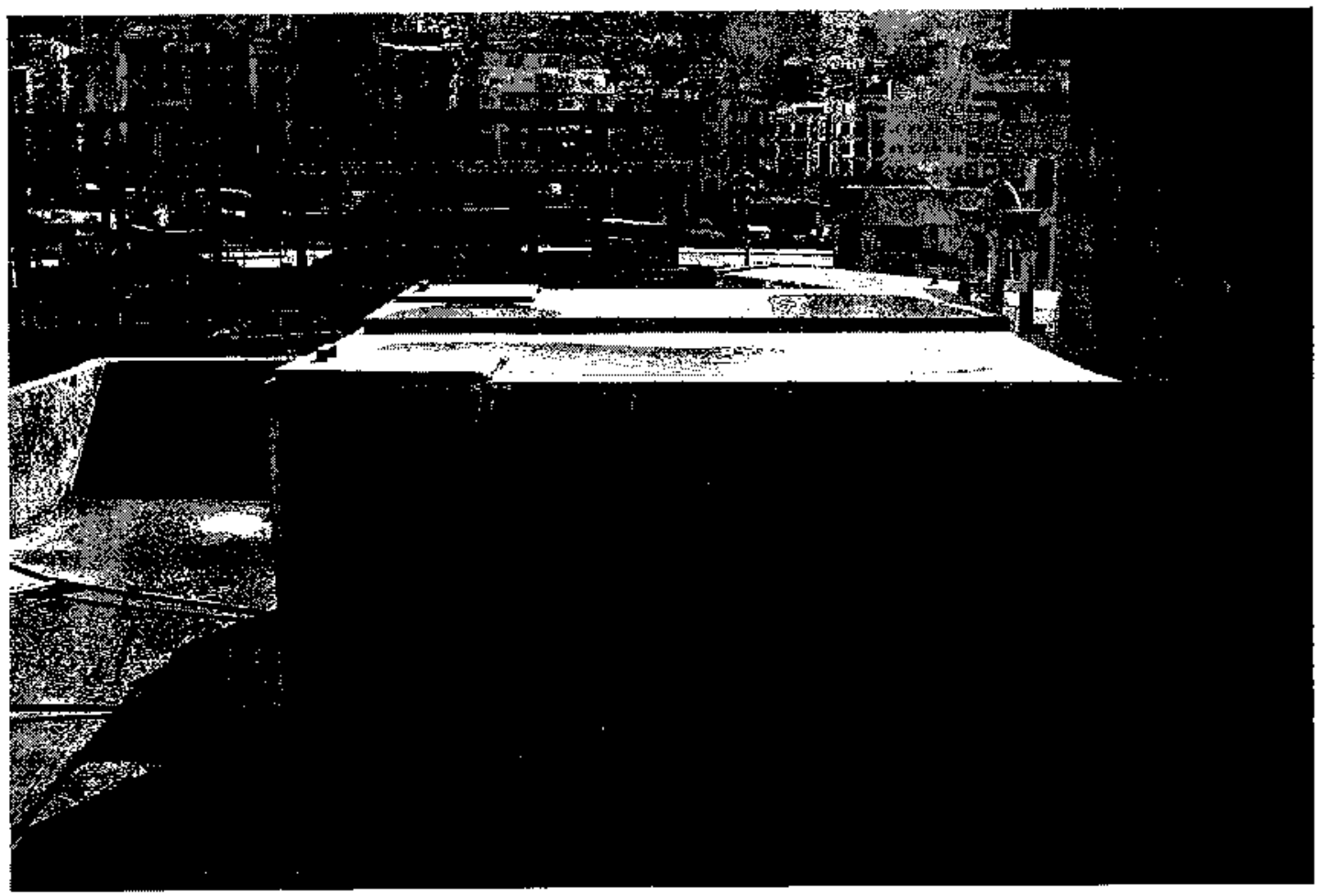

Figure 2: The galvanized cast iron taniks installed on the same building roof top.

\subsubsection{Total bacterial count (HPC) and diversity in the PRWST}

The first series of experiments were held from July till December 2000, a six month period. A total of eight experimental runs were performed during this period.

The objective of this first part of the study was to have a qualitative and quantitative idea of the bacterial population present in the PRWST and in the water inlet supplying the tanks with intermittent chlorinated water. Only the fiberglass tank was cleaned by washing and draining several times in order to avoid any previous contamination that may interfere with the experimental results. This is due to the ease of draining the fiberglass tank from its bottom outlet.

Sampling took place under aseptic conditions from the surface of the following tanks: Polyethylene, cast iron and etemite since there are no outlets at the bottom of these tanks, whereas in the fiberglass sampling was done from the outlet at the bottom of the tank. 
The four tanks were of different sizes: cast iron (2000 liter), black polyethylene (1500 liter), fiberglass (250 liter), and asbestos (750 liter), and were originally installed on the roof of a private building in Byblos (Fig. 182). The chlorinated water influent going into the tanks is coming through a cast iron distribution system from "Hboub" artesian wells $4 \mathrm{~km}$ away from the city center area.

\subsubsection{Effect of water storage (water retention time) on total bacterial counts (HPC)}

This experiment was performed only on the fiberglass tank during April and May 2001 ( 2 runs). The objective behind this experiment was to monitor the effect of water retention time on HPC. Samples were taken from the influent point at zero time where the tank is $100 \%$ full and after 2, 4 and 7 days of storage. Before each sampling day, draining of $20 \%$ of the tank was made in order to mimic human water consumption per day, for the period of one week, following the water distribution pattern followed in Byblos.

Samples in this series of experiments were analyzed for physico-chemical parameters such as temperature, free residual chlorine whenever available, and residence time (RT). In addition, the microbiological and hygienic quality of the water in distribution systems and in all types of storage tanks was determined through identification of isolated heterotrophic bacteria including coliforms. 


\subsection{Description of the Second Study}

\subsubsection{Microbial content of UV - treated water in stomge tanks}

Another controlled study was held on two galvanized cast iron and two black polyethylene tanks, each of 500 liter, installed in open air at the Lebanese American University (LAU, Byblos campus) (Fig. 3).

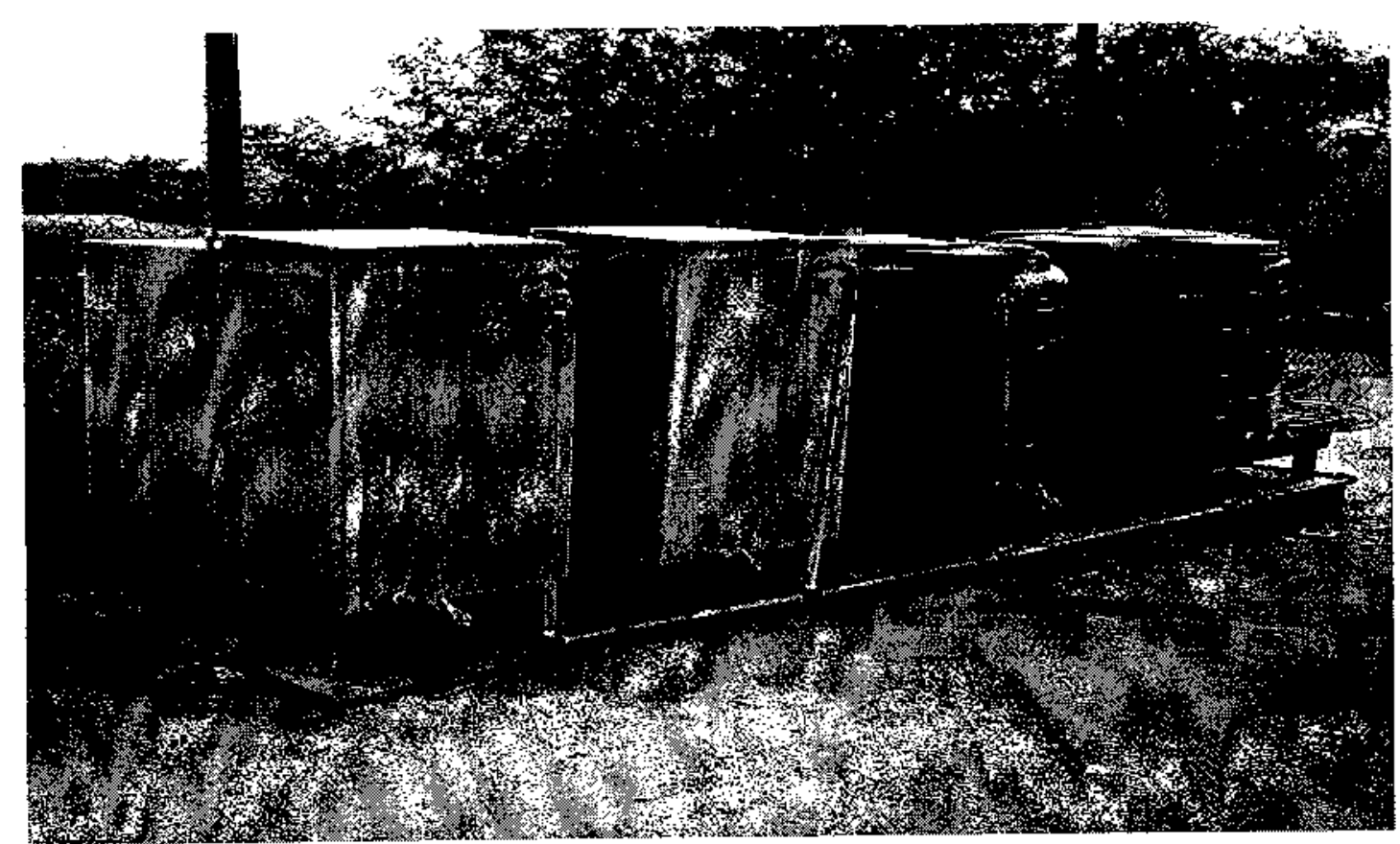

Figure 3: The galvanized cast iron and the polyethylene tanks (each of 500L capacity) installed at LAU. All tanks were supplied with outlets at the bottom.

The water supply is provided through a university owned private well in the Valley directly below the university buildings. Water extracted with a pumping station is subjected to rapid sand filtration and then uitraviolet radiation $(\lambda=254 \mathrm{~nm}$, UV irradiation at a wavelength of $253.7 \mathrm{~nm}\left(\mathrm{UV}_{254}\right)$ is commonly used for drinking water disinfection (Lehtola et al., 2003)). The treated water is pumped and stored in four cast iron tanks (15000 liter each), and then pumped up to a hill above the university in cast iron pipes and stored into two other cast iron reservoirs (15000 liter each). Now the UV treated drinking water reaches the university by gravity. A of the distribution system in the university including the location of the experimental tanks is shown in figure 4 . 


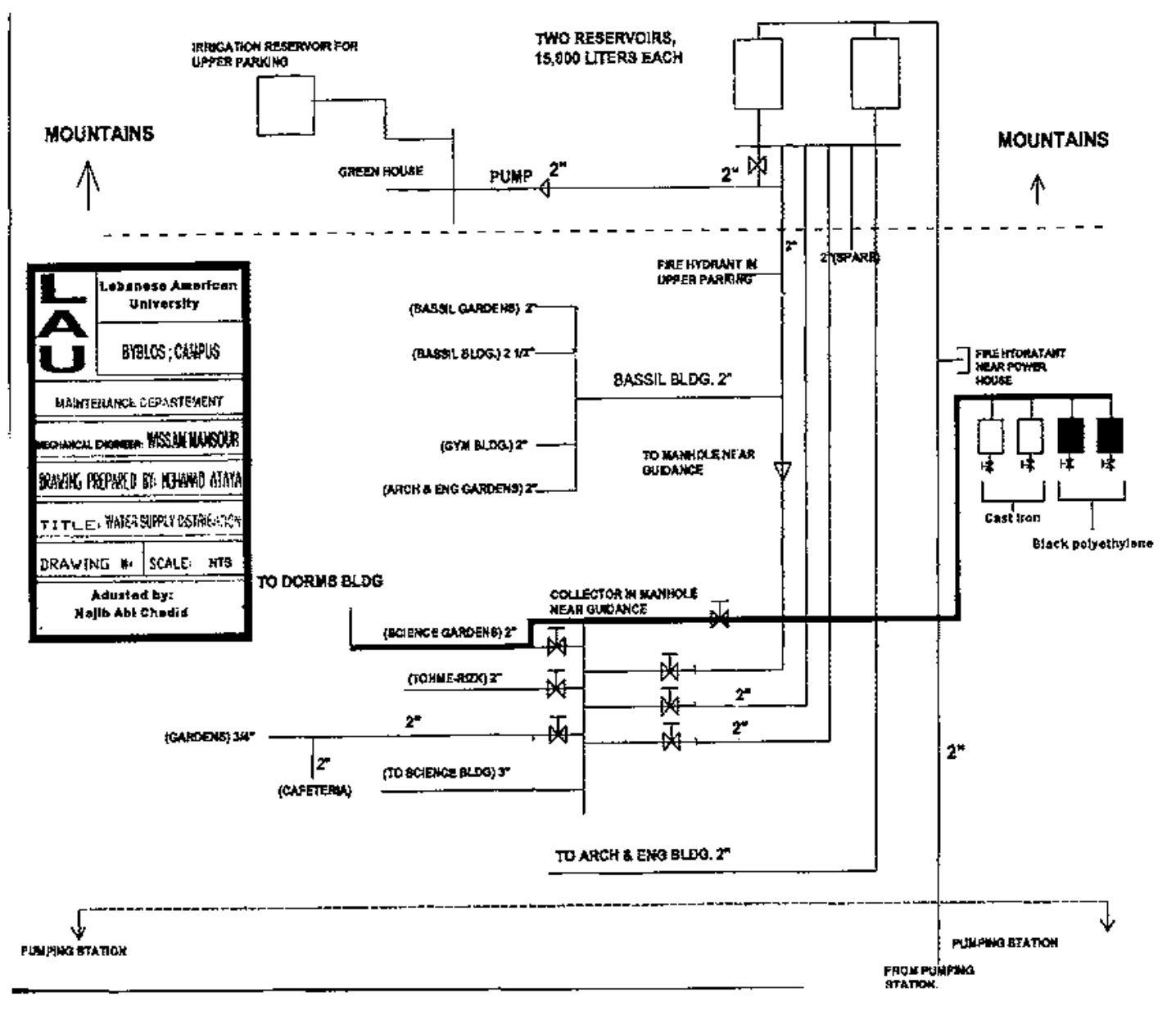

Figure 4: A diagram of the water supply distribution system at LAU. The wide bold black line shows the pipe systems that supply the galvanized cast iron and polyethylene tanks where experimental trials were done.

This study was held during July 2001, in similar fashion to the previous experiment; samples were taken at days $0,2,4$ and 7 from the outlets at the bottom of the tanks. Water temperature was recorded in every sampling.

As it is shown in figure 3 , these tanks were tightly closed and locked from the top and from the outlets at the bottom where sampling took place. Thus any external interference or contamination of the water in the tanks did not occur. Water sampling, laboratory processing, bacteriological analyses, and identification were performed in similar way to the previous experiment and throughout all this study. 


\subsection{Description of the Third Study}

After analyzing the distribution of microorganisms in the black polyethylene and cast iron tanks in the UV treated water, several trials were conducted on the effect of disinfection by chlorination on bacterial distribution in the black polyethylene tanks (Fig. 5). This study was held during August and September 2001 and in similar fashion to the previous experiment sampling took place at days $0,2,4$ and 7 after drainage of both tanks at the same time and same conditions.

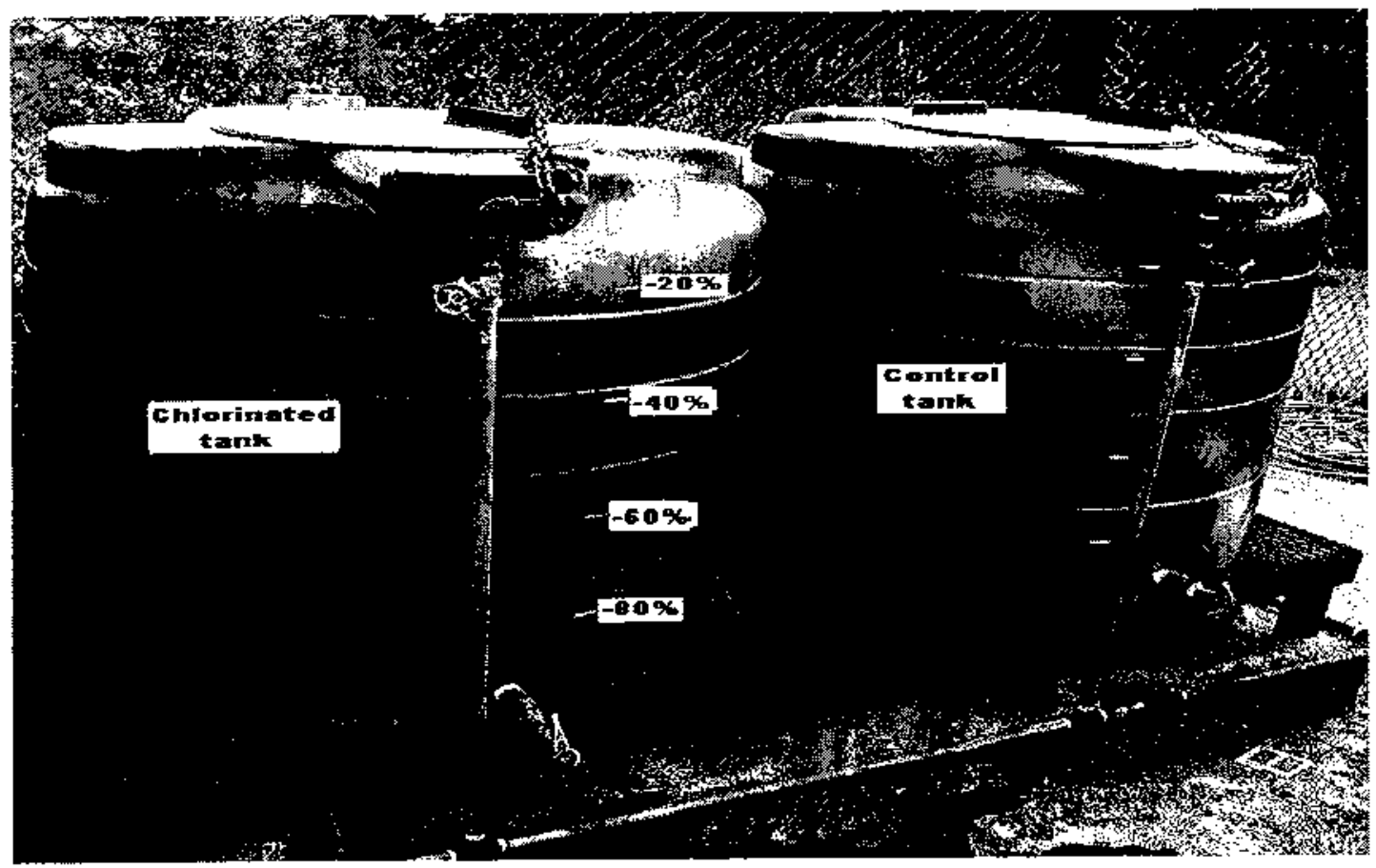

Figure 5: Chlorinated PE water storage tank compared with the control tank Notice the indicated graduations on both tanks for water drainage before each sampling, which mimics domestic water consumption per week.

\subsubsection{Chlorination effect on bacterial counts in the black PE tanks}

Both tanks were designed in a way to control both the inflow and outflow of water in order to maintain acceptable experimental restits. As previously outlined, the inflow of UV treated water is coming through galvanized cast iron distribution system from the primary source, the pumping station reservoirs (Valley), to secondary reservoirs (each of 15000 liter 
of capacity) on the hill. Distribution of UV treated water took place by gravity to all areas in the university including the experimental tanks. Before starting the chlorination experiments, both polyethylene tanks were filled and drained several times.

Chlorine tablets CITERNET (France) made of calcium hypochlorite $\left(\mathrm{CaOHCl}_{2}\right)$ were used (Fig. 6). Each sachet containing 2 tablets of $35 \mathrm{~g}$ and supplied with 2 sites for opening on both ends, the width of the opening determine the concentration of hypochlorite dissolved in water. All sachets were designed to float on the surface of water which were then attached to the inlet fountain in an inverted position (tablets facing the water) so that dissolution would take place. According to the manufacturer label on the back of the sachet, it is stated that every tablet (17.5 g) should be used for tank capacity up to 1500 liter and for duration of one month.

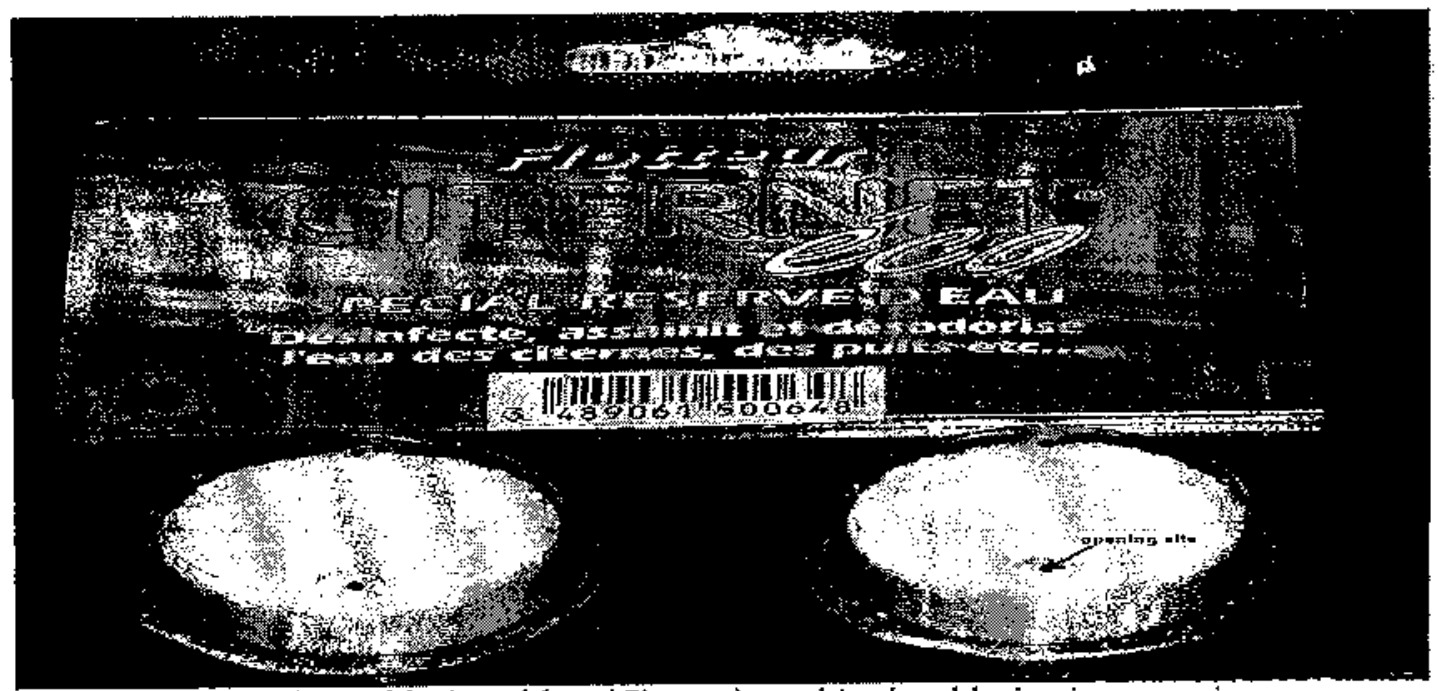

Figure 6: Calcium hypochlorite tablets (Citernet) used in the chlorination experiments.

Only one chlorine tablet was used in the PE water storage tank $(500 \mathrm{~L})$ for chlorination trial.

\subsection{Samples' Collection from the PRWST}

Sampling was done under aseptical conditions, using sterile glass bottles of $300 \mathrm{~mL}$ content each. Water samples were collected once per month from the distribution system (tank influent water), and from each household water storage tank. However, samples were 
collected randomly on a bimonthly basis in August and November. Sodium thiosulfate $\left(\mathrm{Na}_{2} \mathrm{~S}_{2} \mathrm{O}_{3} .5 \mathrm{H}_{2} \mathrm{O}\right)$ was added to sample bottles before sterilization in the autoclave in order to neutralize the effect of residual chlorine present in storage tanks and in the distribution system inlet.

From each tank, a total of eight samples were microbiologically processed during the period of six months so that a better understanding of the quantitative and qualitative water microbiology would be reached.

\subsubsection{Sodium thiosulfate preparation}

$0.1 \mathrm{~mL}$ of a $1.8 \% \mathrm{w} / \mathrm{v}$ solution of sodium thiosulfate was added for each $100 \mathrm{~mL}$ of water bottie capacity (HMSO, 1994).

\subsection{Bacteriological Analyses}

Water samples were placed on ice and analyzed within 1 to $2 \mathrm{~h}$ after sampling. All bacteriological analyses were carried out according to the Standard Method for the Examination of Water and Wastewater (APHA, 1998).

Aseptical conditions were preserved during the bacteriological analyses, so that samples were processed within a laminar flow hood (NuAire, USA) to prevent the growth of any airbome contaminants on the media plates. In addition negative control plates were kept open in the laminar hood during microbiological analyses, and then incubated in order to evaluate the effectiveness of the aseptic conditions kept in the hood.

Total and fecal coliforms were enumerated by the membrane filtration method $(0.45 \mu \mathrm{m}$, Millipore type HA) using Lauryl Sulfate Agar (LSA) plates (Oxoid, England) and were incubated at $37^{\circ} \mathrm{C}$ and $44.5^{\circ} \mathrm{C}$ for 24 to $48 \mathrm{~h}$, respectively.

The heterotrophic plate count bacteria were enumerated by the standard spread plate method using R2A agar (Oxoid), and incubated at $28^{\circ} \mathrm{C}$ for 5 to 7 days. In addition, during this study the spread plate method was compared to the Millipore filtration method and was held on the UV treated water of the cast iron and the polyethylene tanks. 


\subsubsection{Microorganisms identification}

One of the fundamental aspects of microbial ecology is the identification of bacterial species of environmental isolates. Many species of bacteria cannot be rapidly identified by conventional approaches. Among the phenotypic methods, the most widely used commercial identification systems are the API-20E and API-20NE (BioMerieux, France) and the Biolog systems (Biolog inc., USA).

Combinations of spreading and membrane filtration were performed for the HPC using R2A (oxoid) agar plates, and for total and fecal coliforms counts using ISA (oxoid). More than 57 morphologically different colonies were tentatively selected from R2A agar and ISA plates during this study. The isolated colonies were re-streaked on TSA (Mast, England) plates for further purification and later on for identification. Some of the colonies that do not grow on TSA were re-streaked on $\mathrm{R}_{2} \mathrm{~A}$ agar plates.

As pre-identification steps, purified colonies were subjected to routine gram staining procedure to differentiate between gram-positive and gram-negative bacteria, they were also subjected to oxidase and catalase enzyme test.

Furthermore selected colonies were identified according to the API-20NE kits used for the identification of gram-negative non fermentative rods, and API-20E kits for gram-negative fermentative rods. The Biolog GN2 microplates were also used for identification of gramnegative bacteria and Biolog GP2 microplates used for the identification of gram-positive bacteria.

All the pure isolated colonies were stored and kept by inoculation into Tryptone Soya Broth (TSB, Mast) or Nutrient Broth (NB, Mast) with 15 to $20 \%$ glycerol at $-85^{\circ} \mathrm{C}$ in the deep freezer (NuAire, USA) for future identification.

\subsubsection{API procedures}

The API test kit (BioMerieux) consists of enzymatic and carbon compound assimilation test elements. The API-20NE system is a standardized micromethod combining eight conventional tests and 12 assimilation tests for the identification of non-fastidious gramnegative rods not belonging to the Enterobacteriaceae. The API-20NE strip consists of 20 
microtubes containing dehydrated media and substrates. The conventional tests are inoculated with a $2 \mathrm{~mL}$ saline bacterial suspension, which reconstitutes the media. After incubation for 18 to $24 \mathrm{~h}$, metabolism produces color changes that are either spontaneous or revealed by the addition of reagents. The assimilation tests are inoculated with a minimal medium and the bacteria will grow if they are capable of utilizing the corresponding substrate. All reactions were analyzed according to the interpretation chart included in the package insert. The oxidase test was also performed with oxidase reagent. After the results for all biochemicals were obtained, the identification of the organism was made by using the seven-digit number generated (e.g., 5205573) and the analytical profile index ( $5^{\text {th }}$ edition, 1992).

The API-20E test kit for the identification of enteric bacteria (BioMerieux, France) provides an easy way to inoculate and read tests relevant to members of the family Enterobacteriaceae and associated organisms. A plastic strip holding twenty mini-test tubes is inoculated with a saline suspension of a pure culture (as per manufacturer's directions). This process also rehydrates the desiccated medium in each tube. A few tubes are completely filled ( used to test for citrate utilization (CIT), acetoin production (VP) and gelatinase (GEL) as seen in the photo below), and some tubes are overlaid with mineral oil such that anaerobic reactions can be carried out (arginine dihydrolase (ADH), lysine decarboxylase (LDC), ornithine decarboxylase (ODC), $\mathrm{H}_{2} \mathrm{~S}$, urease (URE)) (Fig. 7).

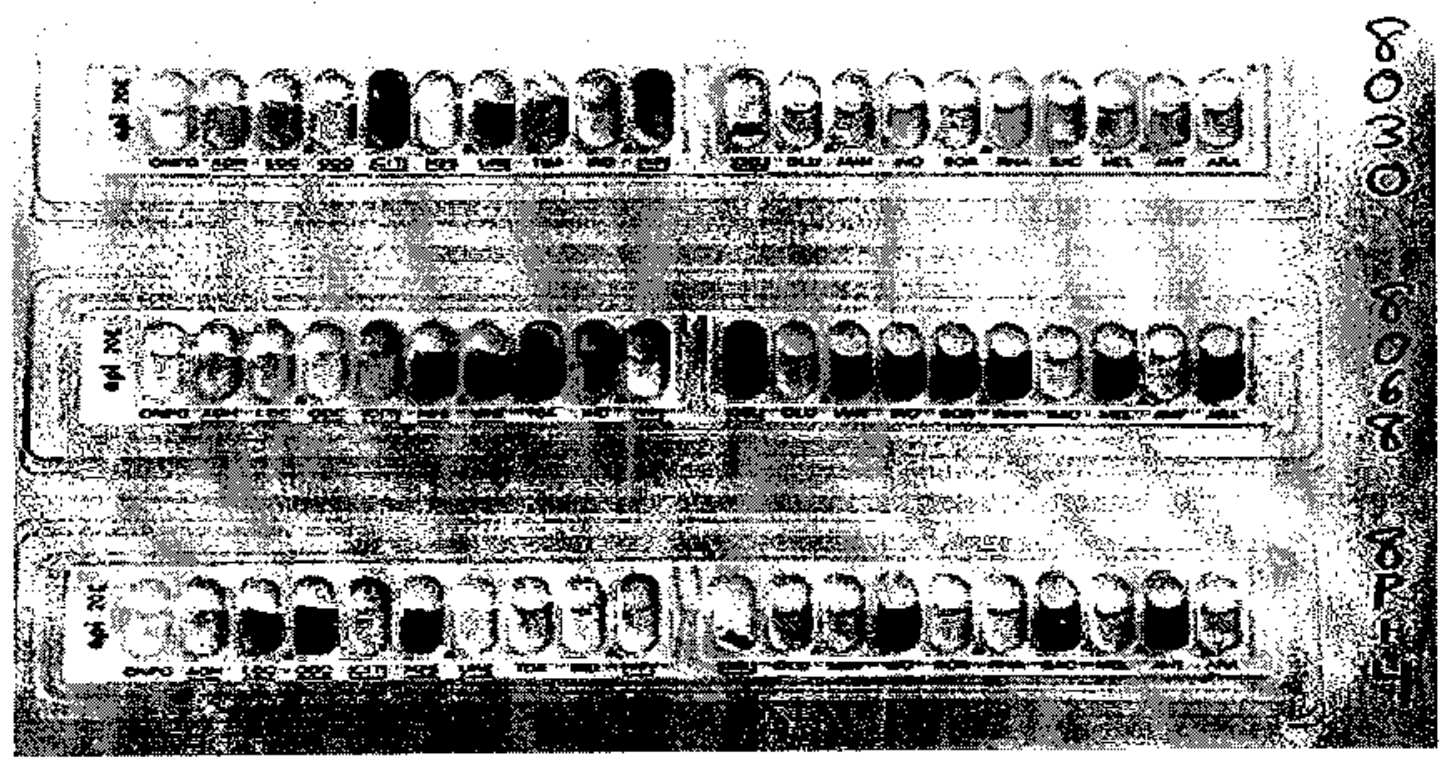

Figure 7: A set of three API-2OE strips each consisting of 20 tests. 
After incubation (Heraeus, Germany) for $18-24$ hours at $37^{\circ} \mathrm{C}$ the color of reactions are read (some with the aid of added reagents), and the reactions (plus the oxidase reaction done separately) are converted to a seven-digit code. Decoding takes place with an API-20E analytical profile index (3rd edition, 1994) for bacterial identification (Supplied by the manufacturer).

In figure 7:

- Note the colored reactions for amino acid decarboxylations (ADH) through (ODC) and carbohydrate fermentations glucose (GLU) through arabinose (ARA).

- The amino acids tested are arginine, lysine and ornithine. Decarboxylation is shown by an alkaline reaction (red color of the specific $\mathrm{pH}$ indicator used).

- The carbohydrates tested are glucose, mannitol, inositol, sorbitol, rhamnose, sucrose, melibiose, amygdalin and arabinose. Fermentation is shown by an acid reaction (yellow color of indicator).

- Hydrogen sulfide production $\left(\mathrm{H}_{2} \mathrm{~S}\right)$ and gelatin hydrolysis (GEL) result in a black color throughout the tube.

- A positive reaction for tryptophan deaminase (TDA) gives a deep brown color with the addition of ferric chloride; positive results for this test correlate with positive phenylalanine and lysine deaminase reactions which are characteristic of the following bacterial genera Proteus, Morganelta and Providencia.

\subsubsection{Biolog procedures (Gorden et al., 1993)}

The Biolog MicroLog 3 identification system (Biolog, Inc., USA) is a bacterial identification method that establishes identifications based on the exchange of electrons generated during respiration, leading subsequently to tetrazolium-based color changes (Fig. 8). 


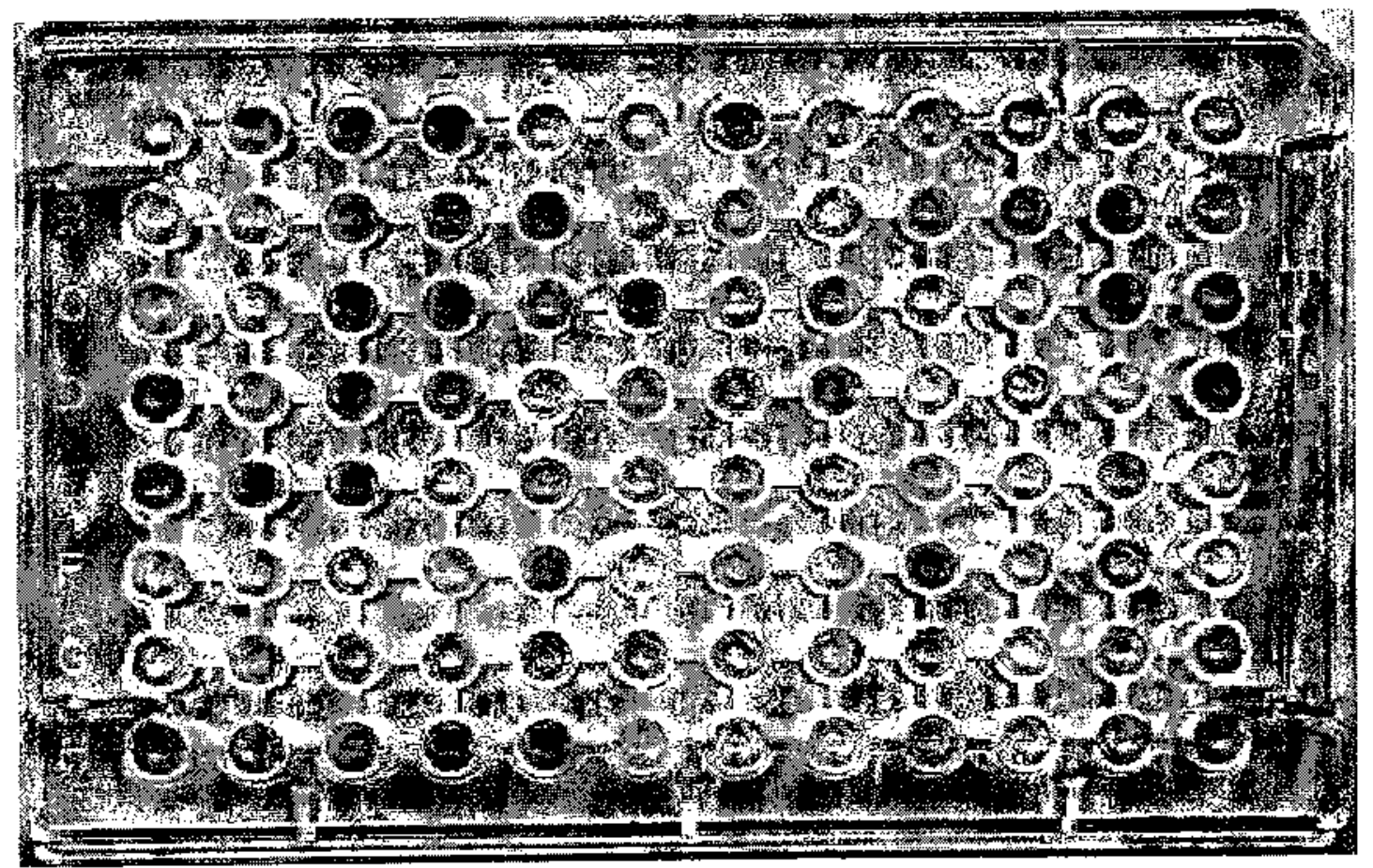

Figure 8: A 96 well plate of inoculated suspension of Bacillus lidhenformis. Compare positive wells (violet color) to the control A1 well.

Although originally designed to identify clinical bacterial isolates, the technology has been extended by Biolog to identify environmental isolates. The Biolog GN2 Microplate ${ }^{\text {TM }}$ test panel provides a standardized micromethod using 96 biochemical tests to identify a broad range of enteric, non-enteric, and fastidious gram-negative bacteria. The Biolog GN2 and GP2 are composed of 96 -well plates that contain pre-dried carbon sources and a tetrazolium violet redox dye that turns purple if the added microorganisms utilize the carbon source. However, the A-1 well of the microtiter plate has no substrate (carbon source), and thus no nutrient source with which to initiate a metabolic reaction with the indicator dye, and consequently serve as a negative control. The test yields a pattern of purple wells which constitutes a "metabolic fingerprint" of the organism. The Biolog automated plate reader was factory programmed to sense a threshold optical density value for each plate based on comparison with the A-1 reference control well (Fig. 9). 


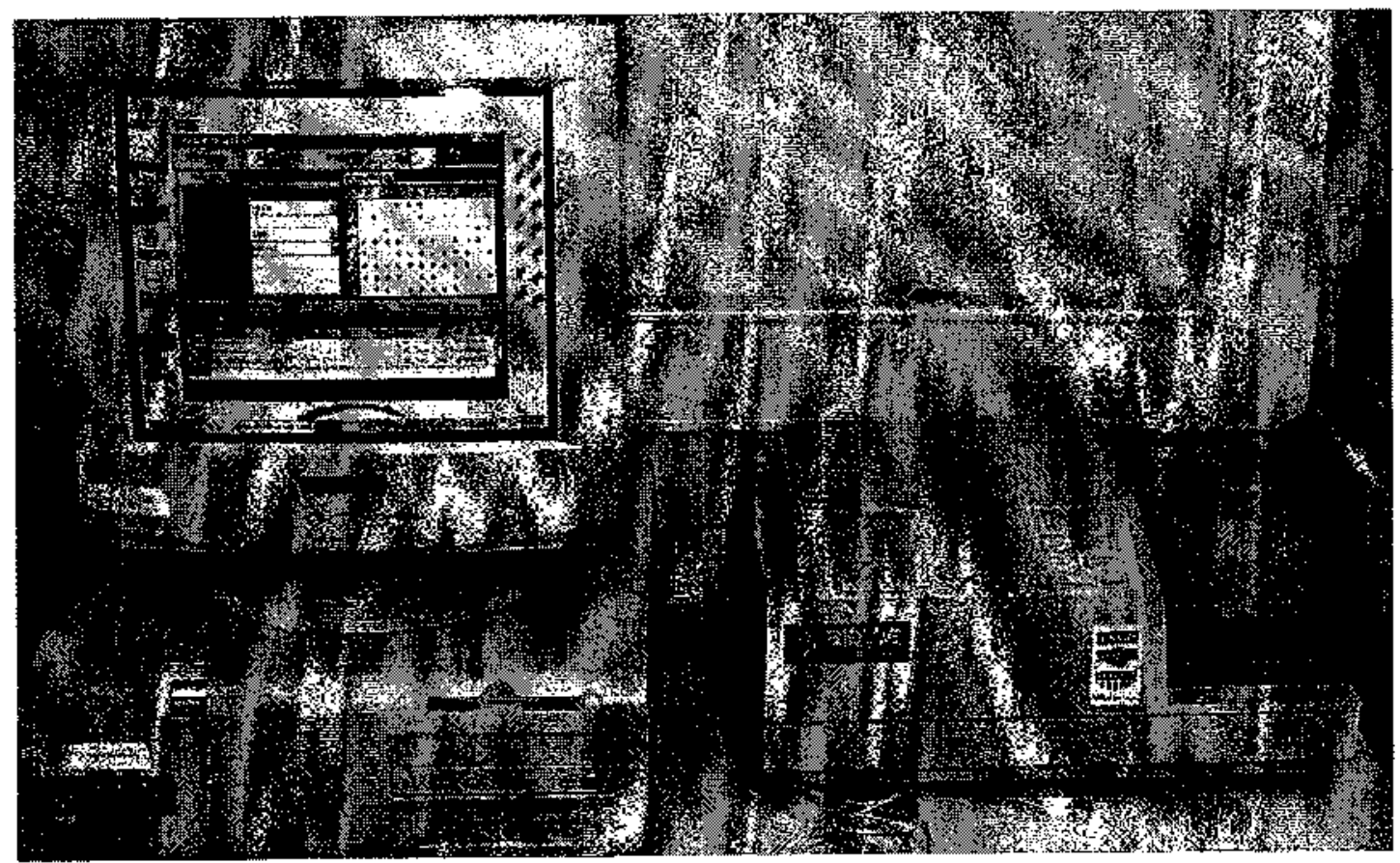

Figure 9: Biolog identification system composed of the microtiter reader (right) and the computer based identification system.

\subsubsection{Biolog microstation system}

The Biolog system consists of a microplate containing 95 different carbon sources and a control well, a turbidimeter, and a computer-driven automatic plate reader. The Biolog plates can be read at $4-6 \mathrm{~h}$ or $16-24 \mathrm{~h}$ to allow the pattern to form. Cultures to be tested were removed from the deep freezer $\left(-85^{\circ} \mathrm{C}\right)$ then thawed and subcultured once on Tryptone Soya Agar (TSA, Mast) and once on Biolog Universal Growth Medium (BUGM) containing $5 \%$ human blood cultures and were then incubated overnight at $30 \circ \mathrm{C}$ for all gram-negative non- enteric organisms and for the gram-positive rods, whereas the gramnegative enteric organisms and the gram-positive are incubated at $35-37^{\circ} \mathrm{C}$

\subsubsection{Inoculum preparation}

The inoculum for testing was prepared from the second subculture by rolling a cotton swab over the pure cultures on the agar plate and preparing a suspension of GN/GP inoculation fluid (GN/GP - IF) in 18 to $20 \mathrm{~mL}$ to establish the appropriate inoculum density relative to standard specified by the manufacturer (roughly equivalent to a range of $52 \%$ GN-NE, $63 \%$ GN-E and to $20 \%$ for GP cocci or rods non-spore formers, transmittance). 
However, for gram-positive non-spore forming rods and for gram-positive cocci as weil as for gram-negative enteric organisms, only 3 drops of concentrated thioglycolate $(5 \mathrm{mM})$ should be added to the 18-20 mL GN/GP-IF (gram-negative/gram-positive inoculation fluid). Thioglycolate acts as an anticapasulate agent and partially or completely inhibits the purple color formation in the control A-1 well and other negative wells that can form when suspended bacteria utilize their polysaccharide capstles as a carbon source. However the gram-positive spore forming rods should be grown on BUGM or TSA $+0.25 \%$ maltose, according to the manufacturer. The resulting suspension was poured into sterile empty Petri dishes. By using an eight-channel repeating pipette (Biolog inc., USA) fitted with $1.500 \mu \mathrm{L}$-capacity sterile tips (Biolog), precisely $150 \mu \mathrm{L}$ of the suspension was dispensed into each well of the microplate (Fig. 10).

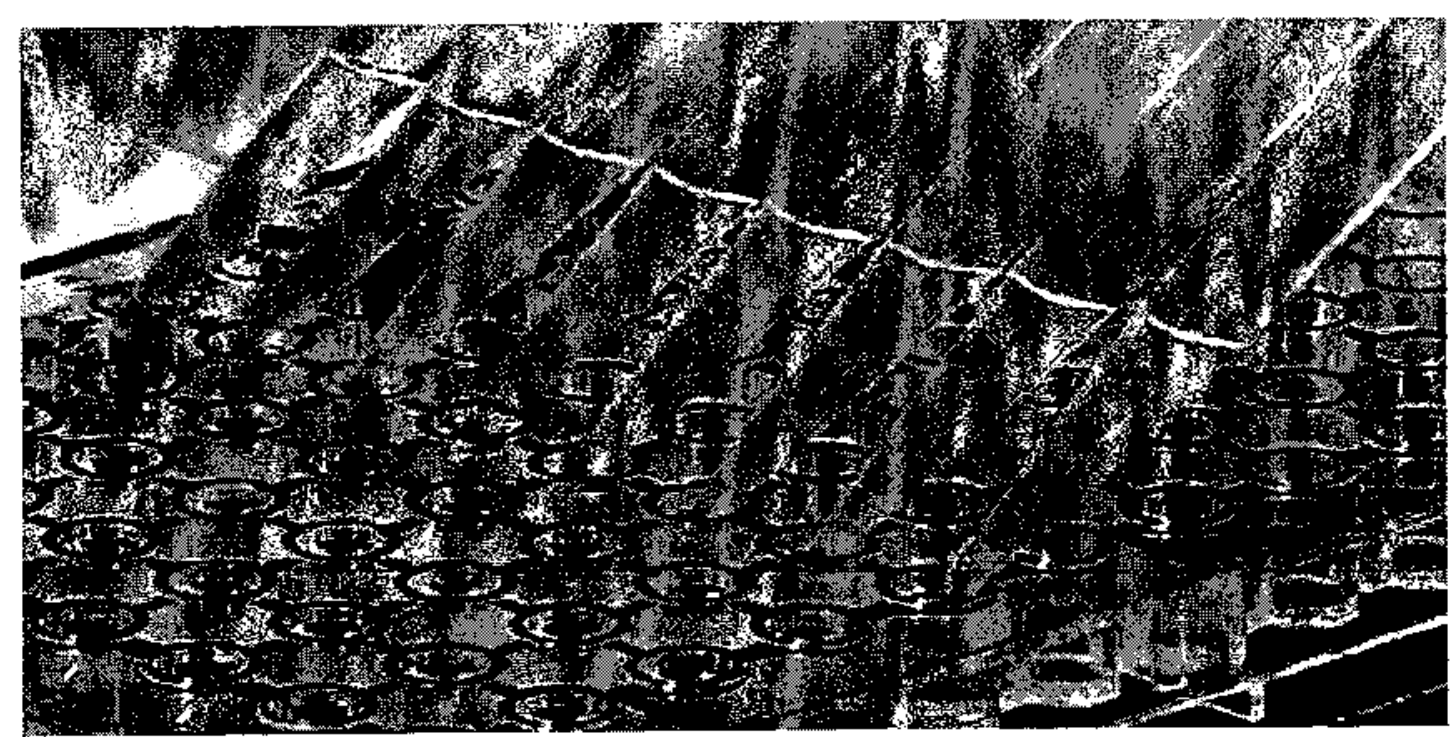

Figure 10: Biolog microtiter plate consisting of 96 wells each. An inoculation of bacterial suspension is taking place with an eight-channeled repeating pipette.

The lid was replaced, and the microplate was incubated at $30^{\circ} \mathrm{C}$ and $35^{\circ} \mathrm{C}$ respectively for Enterics and Non enterics. The Biolog Microplate reader calculates a similanity index for the 10 strains in the data base library most closely related to the test strain. At $24 \mathrm{~h}$ (suggested plate reading time), a similarity index of less than 0.500 results in an instrument report of not identified (NI). If the similarity index is between 0.50 and 0.74 at $24 \mathrm{~h}$, a "good identification" is reported, along with a genus and species name. "Excellent identification" is reserved for indices of 0.75 or greater (Fig. 11812). 


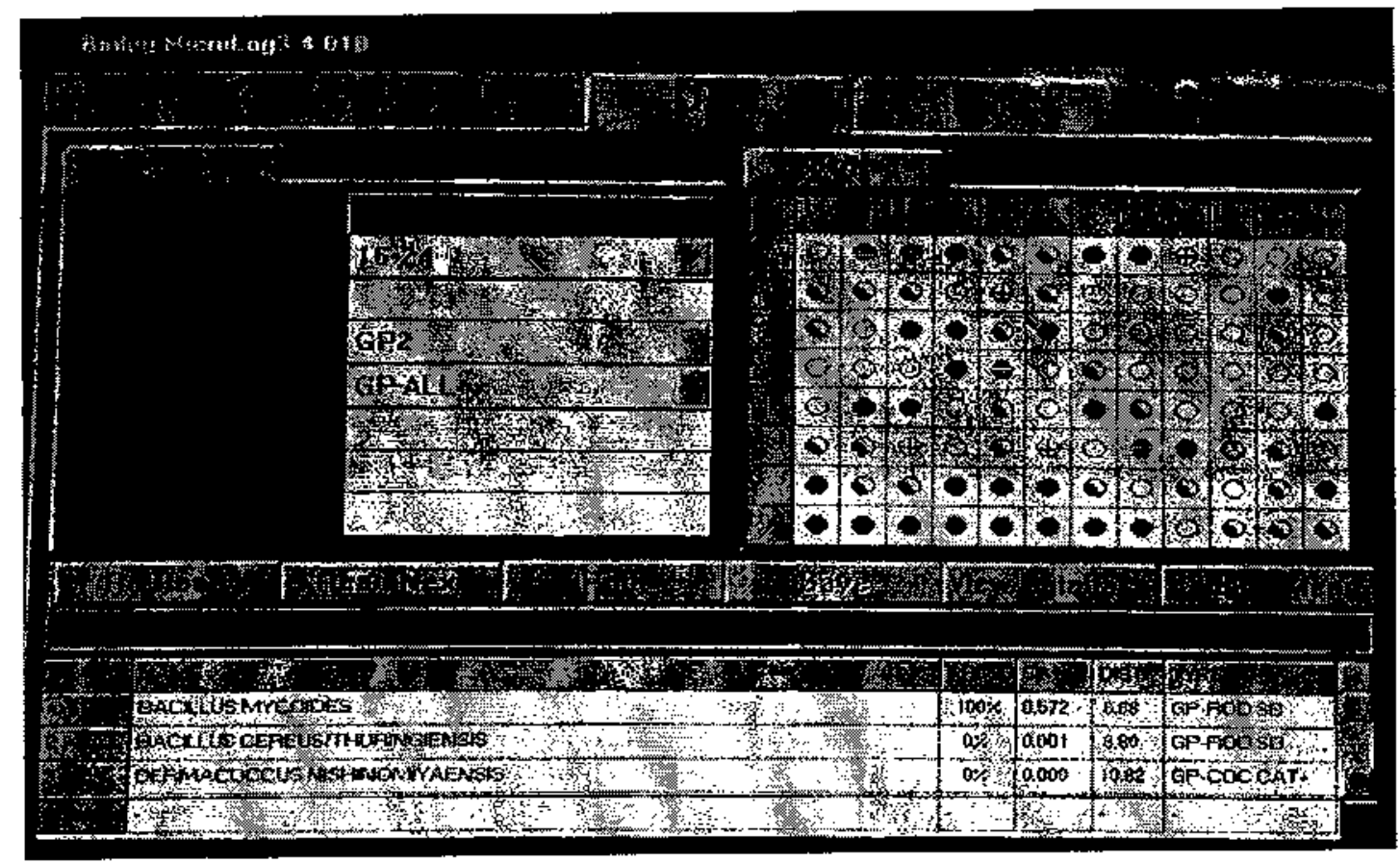

Figure 11: Bacillus mocides a gram-positive rod endospore former (GP-ROD SB) bacterium identified by the Biolog system. A "good identification" since similarity index (SIM) is 0.572 with a $100 \%$ probability.

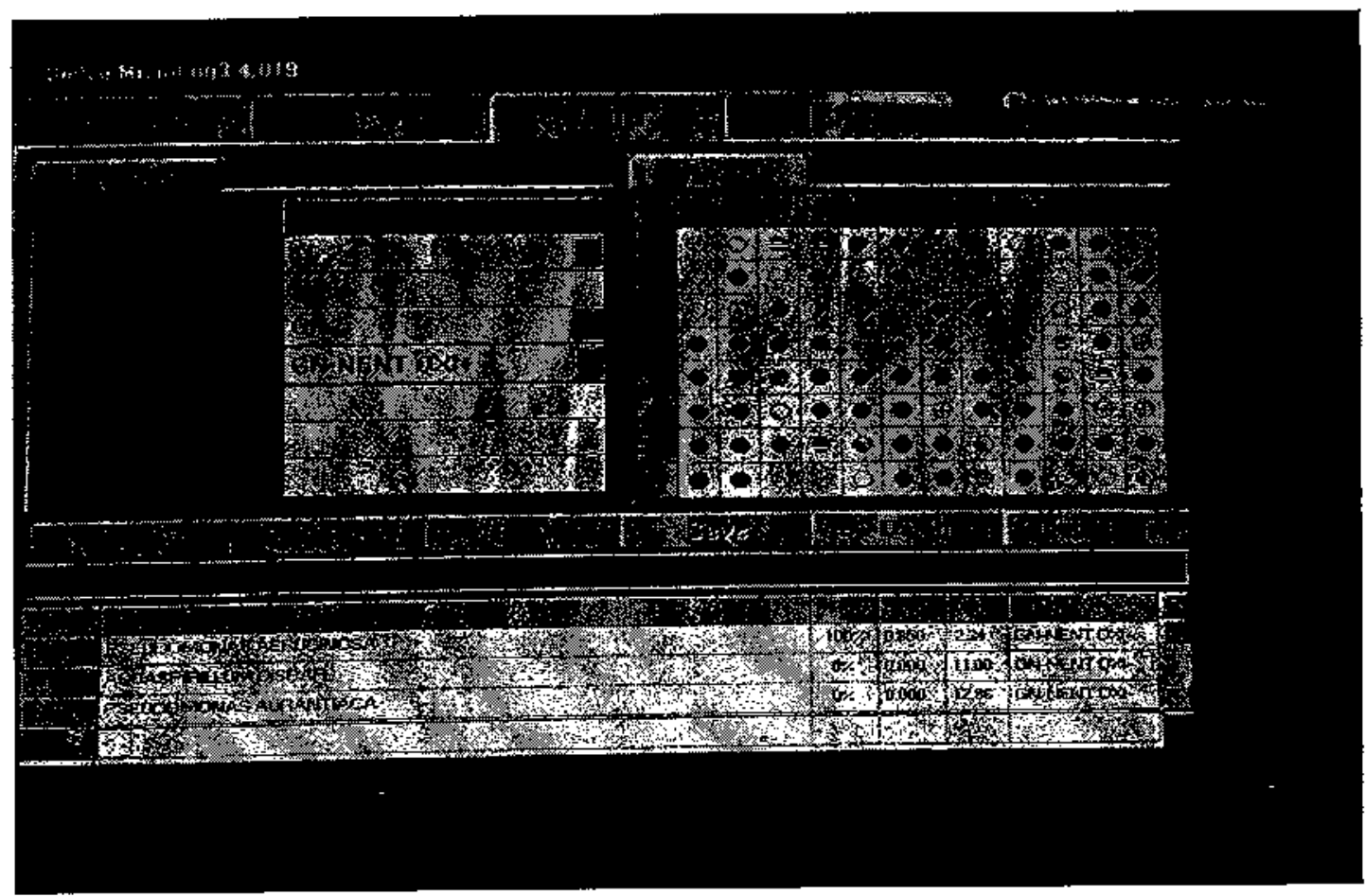

Figure 12: A gram-negative non enteric (GN-NENT) bacterium identified as $P$. aeruginosa. 


\subsubsection{Efficiency of the Biolog system: BUGM vs. TSA}

During this study, standard cultures of the gram-positive cocci Staphylooocus auneus ssp anmeus ATCC 12600 (Culti-Loops ${ }^{*}$ ) and the gram-negative non enteric bacilli Odmobactrumanthropi ATCC 49687 (Culti-Loops ${ }^{8}$ ) were inoculated consecutively on TSA and on BUGM supplied both with $5 \%$ human blood. This experiment was held in order to check for the accuracy and efficiency of the Biolog system as weil as to evaluate the usage of TSA instead of BUGM. Results showed that there were $100 \%$ similarities in identification for the above mentioned bacteria using the Biolog system regardless of any media type used.

\subsection{Physico-Chemical Analyses}

Physico-chemical analyses were performed according to Standard Method for the Examination of Water and Wastewater (APHA et al., 1998). Water temperature, $\mathrm{pH}$ and residual chlorine were determined. Water temperature was read using a digital immersion thermometer installed in each tank directly before sampling (Electro-Therm, Model SH66A, USA). Measurements of $\mathrm{pH}$ were done with a digital $\mathrm{pH}$ meter (Sargent-Welch, USA). Free available chlorine was measured using a DPD colorimetric method (Hach, pocket colorimeter) (Fig. 13).

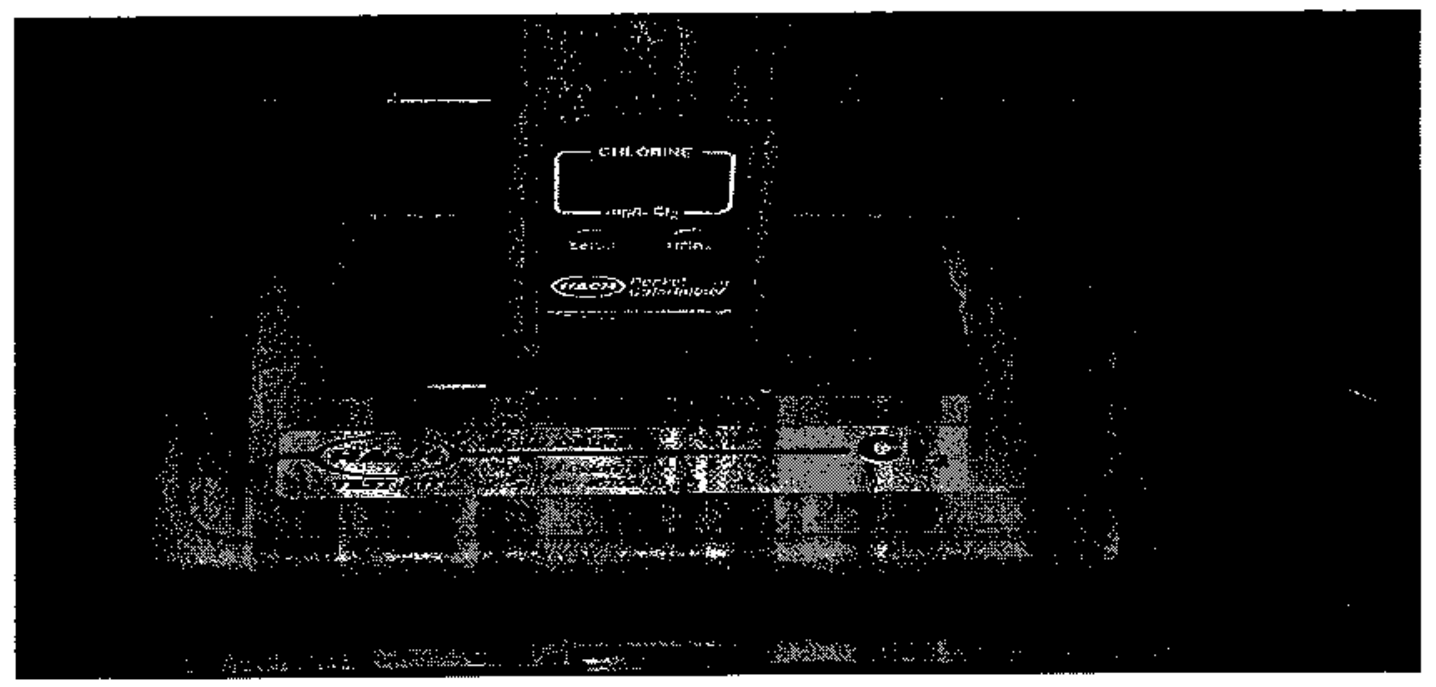

Figure 13: Hach pocket colorimeter used for residual free chlorine and total chlorine testing.

Concentrations of disinfectants were measured directly upon taking samples using the $\mathrm{N}$, $N^{\prime}$ - diethyl-p-phenylenediamine (DPD-Fach). 


\section{Cbapter 4}

\section{RESULTS}

\subsection{Spreading vs. Filtration Microbiological Technique vs. HPC: (PE \& Cast Iron Tanks)}

In order to set an improved microbiological method for water samples analyses. One experiment was held during one week of experimental sampling on both $\mathrm{PE}$ and cast iron water storage tanks. The same volumes of water samples were filtered and spreaded in triplicates in order to maintain satisfactory experimental results (Fig. 14).

Spreading techrique vs. filtration in the Black polyethylene tanks

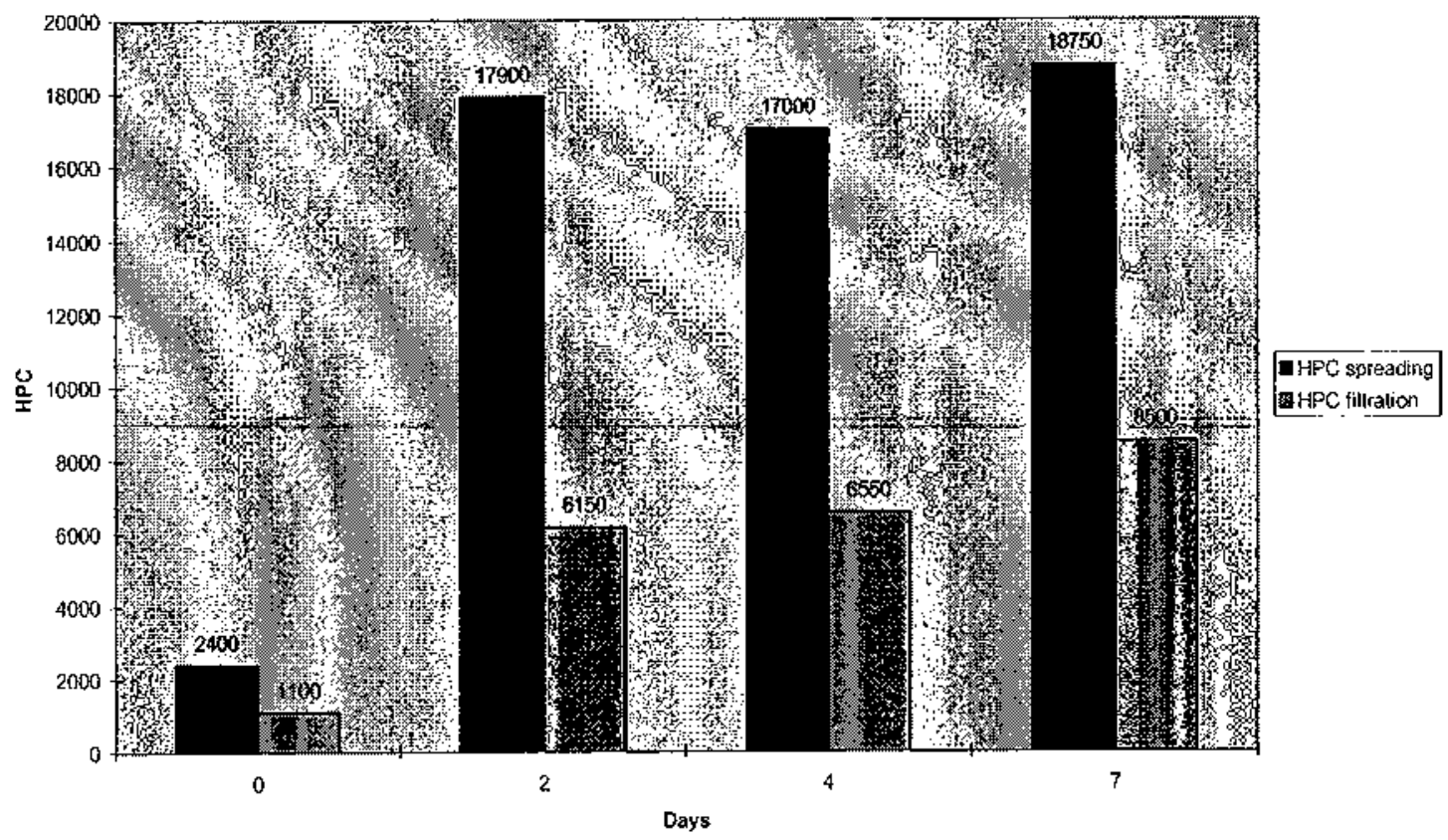

Figure 14: Spreading vs. filtration technique related to HPC level in the PE water storage tank

As results showed in the figure above, HPC levels by spreading technique were higher in the range of 2.2 to 2.9 times as compared with filtration technique. 


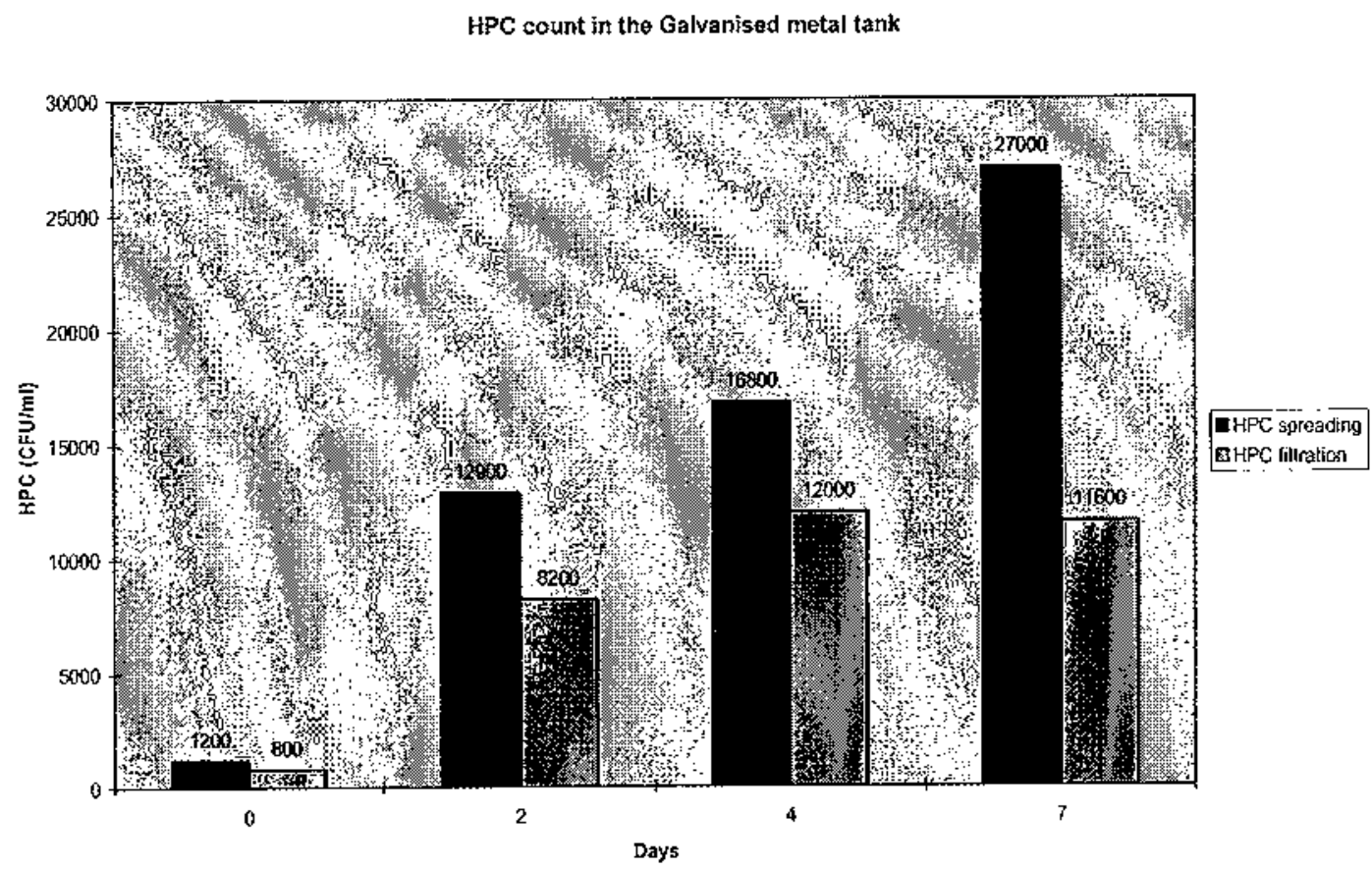

Figure 15: Spreading vs. filtration technique related to HPC in the cast iron water storage tank.

On the other hand, as it was clearly shown in the figure above, and in concomitance with the results of the PE tanks, HPC levels by the spreading technique were higher in the range of 1.5 to 2.3 times than the filtration technique in the cast iron tanks (Fig. 15).

It is valuable to note that more diversity of microorganisms could be detected in the filtration technique relative to the spreading technique.

All colonies growing on R2A plates were enumerated and isolated, whereas only yellow pigmented colonies growing on ISA were presumptively considered as coliforms and stored for further identification. 


\subsection{Microbiological Quality of the Water in the PRWST}

Bacteriological results are summarized in table 1. P. aeruginosa was found in $68 \%$ (19 of 28) of the samples, total and fecal coliforms in $39 \%$ (11 of 28 ) and $4 \%$ (1 of 28 ), respectively (Fig. 16). HPC bacteria were found in all the samples with concentrations from $10^{1}$ to $10^{4}$ $\mathrm{CFU} / \mathrm{mL}$ (Fig. 17). HPC bacteria were considered positive if their levels were greater than $500 \mathrm{CFU} / \mathrm{mL}$ (EPA, 1986). Thus HPC bacteria positive samples were $57 \%$ (16 of 28 ).

$P$. aemuginosa isolates were confirmed by the API-20NE system (BioMerieux), and selected colonies "yellow-pigmented" from Lauryl Sulfate Agar (LSA, Oxoid) were confirmed by the API 20E system (BioMerieux). The predominant bacteria in the coliforms group were Enterobader sakazakii and to a lesser extent $E$. agglomerans 5, Khayrera spp. and Citrobadter fremdii. The only fecal coliform detected were C. freundii (Table 1).

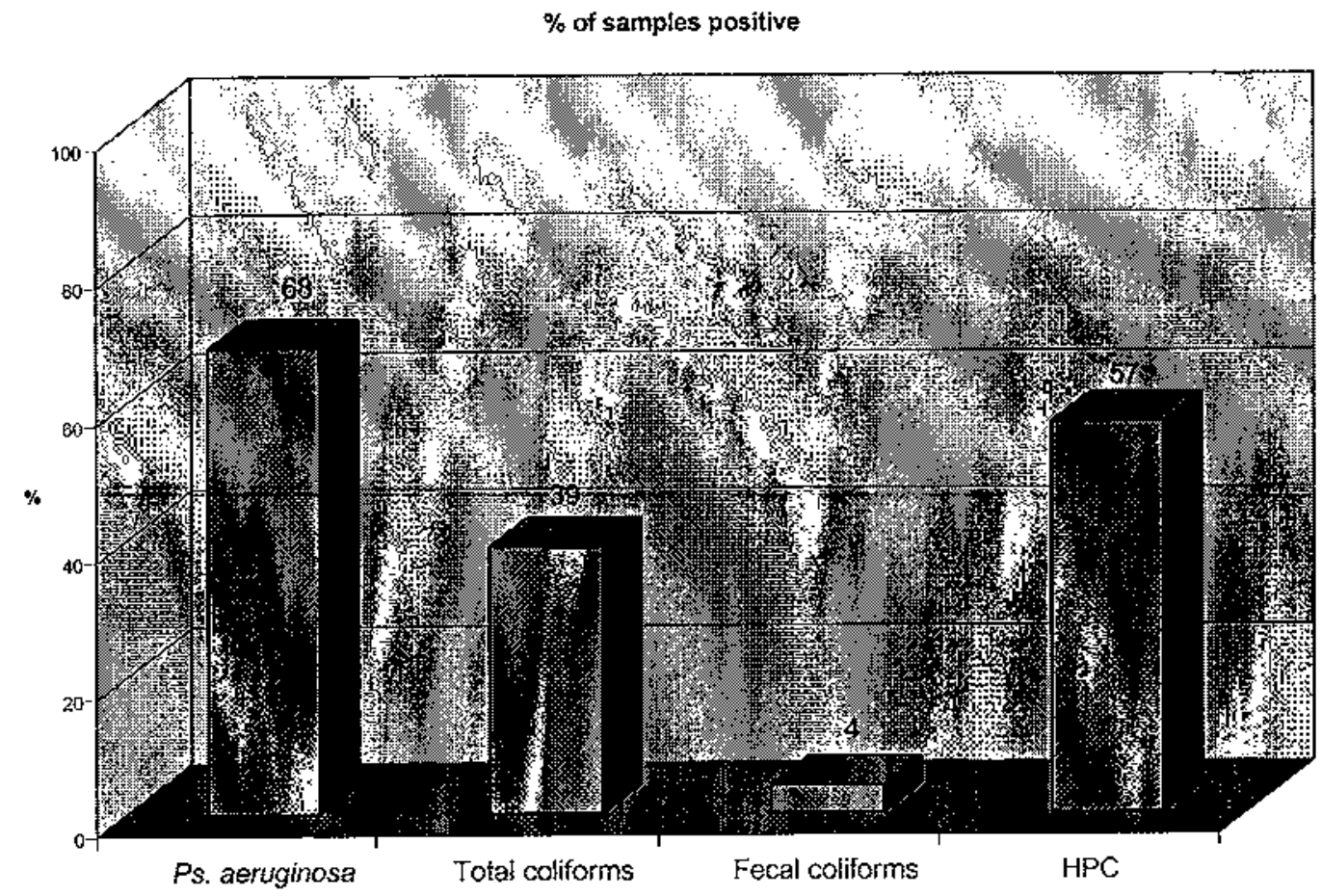

Figure 16: Percentage of samples positive for P. aeruginosa $(\mathrm{CFU} / 100 \mathrm{~mL})$, total and fecal coliforms (CFU/100 mL) and HPC bacteria $(>500 \mathrm{CFU} / \mathrm{mL})$. 
Table 1: Bacteriological quality of water in the PRWST and the drinking water inlet.

\begin{tabular}{|c|c|c|c|c|}
\hline PRWST & $\begin{array}{l}P \text { aeruginosa } \\
\text { CFU/ } 100 \mathrm{~mL}\end{array}$ & $\begin{array}{l}\text { Total Coliforms } \\
\text { (TC) CFU } / 100 \mathrm{~mL}\end{array}$ & $\begin{array}{l}\text { Fecal } \\
\text { Coliforms } \\
\text { CFU } / 100 \mathrm{~mL}\end{array}$ & $\begin{array}{l}\mathrm{HPC} \\
\mathrm{CFU} / \mathrm{mL}\end{array}$ \\
\hline Eternite & $(19$ out of 28$)$ & A (11 out of 28$)$ & (1 out of 28 ) & (16 out of 28$)$ \\
\hline S1 (July) & 120 & 20 & 0 & 112 \\
\hline "S2(Aug) & 5 & $200^{*}$ (2 times) & 0 & 102 \\
\hline S3 (Sep) & 2 & 0 & 0 & 72 \\
\hline $\mathrm{S} 4(\mathrm{Oct})$ & 10 & 0 & 0 & 8230 \\
\hline H5 (Nov) & $20^{*}(2$ times $)$ & $500^{*}$ (2 times) & 0 & $11390^{*}$ (2 times) \\
\hline S6 (Dec) & 400 & 5000 & 0 & 40330 \\
\hline Fiberglass & & $\mathrm{B}$ & $\mathrm{B} 1$ & \\
\hline S1 (July) & 0 & 0 & 0 & 184 \\
\hline "S2 (Aug) & 0 & 10 & 10 & 78 \\
\hline S3 (Sep) & 0 & 0 & 0 & 151 \\
\hline S4 (Oct) & 11 & 60 & 0 & 1590 \\
\hline S5 (Nov) & 40 & $3000 *$ (2 times) & 0 & $7995 \%$ (2 times) \\
\hline S6 (Dec) & 320 & 0 & 0 & 32920 \\
\hline Cast iron & & $\overline{\mathrm{A}}$ & & \\
\hline S1 (July) & 16 & 0 & 0 & 5 \\
\hline *S2 (Aug) & 2 & 0 & 0 & 11 \\
\hline S3 (Sep) & 0 & 0 & 0 & 30 \\
\hline S4 (Oct) & 10 & 2 & 0 & 1120 \\
\hline "S5 (Nov) & $32 *(2$ times $)$ & 0 & 0 & $8300^{\circ}$ (2 times) \\
\hline S6 (Dec) & 400 & 0 & 0 & 40040 \\
\hline \multicolumn{5}{|l|}{ Polyethylene } \\
\hline $\mathrm{S} 4$ (Oct) & 9 & 0 & 0 & 10337 \\
\hline *S5 (Nov) & 5 & 0 & 0 & $10035^{*}$ (2 times) \\
\hline S6 (Dec) & 380 & 0 & 0 & 40000 \\
\hline \multirow[t]{2}{*}{$\begin{array}{l}\text { Drinking } \\
\text { Water Inlet }\end{array}$} & $\begin{array}{l}\text { P. aenuginosa } \\
\mathrm{CFU} / 100 \mathrm{~mL}\end{array}$ & $\begin{array}{l}\text { Total Coliforms } \\
\text { CFU/ 100mL }\end{array}$ & $\begin{array}{l}\text { Fecal } \\
\text { Coliforms }\end{array}$ & $\begin{array}{l}\mathrm{HPC} \\
\mathrm{CFU} / \mathrm{mL}\end{array}$ \\
\hline & (2 out of 7$)$ & $\mathrm{C}(4$ out of 7$)$ & & (3 out of 7 ) \\
\hline S1 (July) & 0 & 0 & 0 & 40 \\
\hline S2 (Aug.) & 0 & 8 (3 times) & 0 & 39 \\
\hline S3 (Sep) & 0 & 0 & 0 & 36 \\
\hline S4 (Oct.) & 0 & 5 (1 time) & 0 & 2184 \\
\hline "S5 (Nov.) & $2^{*}(2$ times $)$ & 0 & 0 & 500 (1 time) \\
\hline S6 (Dec) & 0 & 0 & 0 & $6000^{\circ}$ \\
\hline
\end{tabular}

* The mean value of the data was shown ( 2 samples were taken at these months).
A: Enterdacter sakazakü
B: Citrobacter fremadi, E. sakazakü, E. agstomerans 5, and Klignera spp.
B 1: Citrobacter fremdii
C. E. agotomerans 3, E. sakazakii, and Khorera spp. 


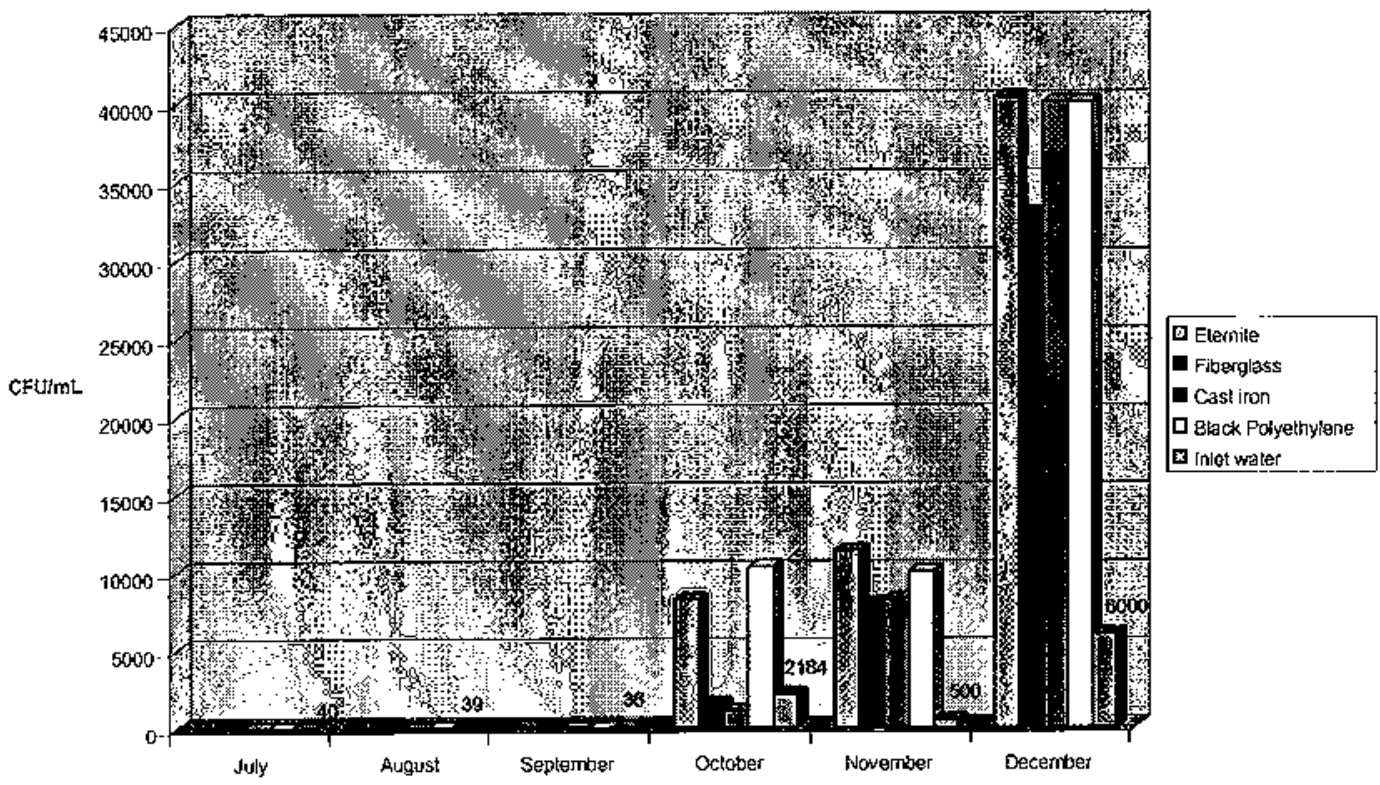

Figure 17: Summary of total HPC in the PRWST and the drinking water inlet.

In the PRWST, a total of 49 different colony forming units (CFU) were isolated during the period of study. Up to 35 isolates (71.4\%) of gram-negative bacteria as well as $13 \mathrm{gram}$ positive isolates $(26.5 \%)$ were collected. In addition, only one yeast isolate $(2 \%)$ was cultured and identified as Rbodotonda tontlepsis ( $4 \times 10^{-3} \%$ of all cultures) from the fiberglass tank in November 2000 , this isolate could be an airborne contaminant.

Out of the 35 isolates only 4 isolates could not be identified by the API-20NE system, but half of them ( 2 isolates) were re-identified as members of the Psendommas group using the Biolog GN microplates. Only one isolate (2.86\%) was lost upon subsequent culturing. This lost culture was suspected to belong to the Actinomycetes family specifically the Streptompes spp. (found in the soil) since it showed a characteristic bloody red coloration on $\mathrm{R} 2 \mathrm{~A}$ and the presence of pseudohyphae upon microscopy (Fig. 18, right).

The predominant bacteria in the non-fermenters were Pseudomonas spp. (42\%, count wise) especially $P$. aeruginas $26.2 \%$ which had the highest occurrence. Furthermore, Butkbolderia apacia (formerly $P$. apacia) had a significant outcome of $18.9 \%$ (Table 2). 
On the other hand among the coliform group isolated, Enterobater sakazakii was the predominant bacteria with $0.15 \%$ of occurrence. C freundii $(0.013 \%)$ the only fecal coliform detected in the fiberglass water storage tank (Table 2).

Table 2: Percentage occurrences of the gram-negative bacteria isolated from the PRWST. Identification performed by the API system.

\begin{tabular}{|c|c|c|}
\hline $\begin{array}{l}\text { Gram-negative bacteria }\left(\mathrm{NF}^{*}\right) \\
\text { (Genus species \& stubspecies) }\end{array}$ & $\begin{array}{l}\text { Colony Description on R2A } \\
\text { (Fermenters on LSA) }\end{array}$ & $\begin{array}{l}\% \\
\text { Occurrence } \\
\text { (count wise) }\end{array}$ \\
\hline Pseudomonas aenuginosa & $\begin{array}{l}\text { - Whitish brown tiny flat } \\
\text { - White medium greenish-blue } \\
\text { zone }\end{array}$ & 26.2 \\
\hline Bumkbolderia cepacia (P. copacia) & $\begin{array}{l}\text { - Whitish grey, raised slimy } \\
\text { small, green zone } \\
\text { - Yellowish green raised slimy }\end{array}$ & 18.9 \\
\hline P. fluorescens & Brown colony, green zone & 9.33 \\
\hline Agrobacterium radiobater & $\begin{array}{l}\text { - Dull orange moist, small } \\
\text { - Brown curly moist small } \\
\text { - White slimy }(13 \text { streaks })\end{array}$ & 3.59 \\
\hline P. putida & Mild whitish pink, slimy convex & 2.25 \\
\hline P. stutzeri & $\begin{array}{l}\text { - Tiny violet moist raised } \\
\text { - Brown to orange small } \\
\text { - Mright yellow small } \\
\text { - Mild green small }\end{array}$ & 2.19 \\
\hline CDCgr. IV C2 2 \# dose to Bordetella & White creamy tiny & 2.15 \\
\hline $\begin{array}{l}\text { Empedobater brezis (Flawobateritm } \\
\text { brewe) }\end{array}$ & $\begin{array}{l}\text { - Yellowish brown moist } \\
\text { convex tiny } \\
\text { - Greenish yellow small }\end{array}$ & 2.10 \\
\hline Breumatimonas zesiaularis $\left(P_{S .}\right)$ & Yellow brown centered moist & 1.75 \\
\hline Alcaligenes xyloscoxydans xylosax ydans & Pink to orange moist convex tiny & 0.84 \\
\hline Pastemmella baematytica & White, moist flat medium & 0.63 \\
\hline Flawbacterium indologenes & Yellow transparent convex medium & 0.43 \\
\hline P. alcaligenes & LSA: Orange convex tiny dry & 0.31 \\
\hline $\begin{array}{l}\text { Week sella rirosa }(48 \%) \\
\text { or Flat dacterium brete }(32 \%)\end{array}$ & Yellow to white small entire moist & 0.13 \\
\hline Sphingomonds paucimobilis & Yellowish orange tiny moist & 0.11 \\
\hline Pseudomonas spp. & White to brown, dry big and flat & 0.10 \\
\hline Alcaligenes faecalis & Mild white tiny slimy & 0.088 \\
\hline
\end{tabular}




\begin{tabular}{|c|c|c|}
\hline Odbrobactenumanthropi & $\begin{array}{l}\text { Creamy big concentric brown } \\
\text { centered moist }\end{array}$ & 0.045 \\
\hline P. mespopilica & Cear yellow moist smail & 0.045 \\
\hline P. dhlororaphis & Brown small entire & 0.037 \\
\hline $\begin{array}{l}\text { A cinatdoater spp., asaccharolytic, } \\
\text { nonhemolytic old (A. lreoffii }(49.5 \%) \\
\text { or } A \text {.jumi }(45.5 \%))\end{array}$ & White raised smooth moist small & 0.031 \\
\hline Omsermonas luteda & $\begin{array}{l}\text { - Mild green to yellow } \\
\text { medium } \\
\text { - Brown to yellow medium }\end{array}$ & 0.013 \\
\hline A eromonas sobria (Fermenter) & $\begin{array}{l}\text { LSA: dull red, yellow on borders } \\
\text { small moist rigid gel }\end{array}$ & 0.008 \\
\hline Erreinia sp. & Yellow moist small & 0.001 \\
\hline pastemella sp. & White dry small & 0.001 \\
\hline P. putida biotype A (Biolog, $93 \%$ ) & Creamy white medium umbonate & 0.003 \\
\hline Pseudomnas sp.(Biolog) & White to brown slimy convex, small & 0.72 \\
\hline Unidentified (E7006) & $\begin{array}{l}\text { ISA: Shiny red big curly on top hard } \\
\text { slime }\end{array}$ & 0.29 \\
\hline Unidentified (FR90025) & Dull orange dry small & 0.041 \\
\hline $\begin{array}{l}\text { Lost upon isolation } \\
\text { suspected : Streptomyes spp. }\end{array}$ & $\begin{array}{l}\text { Bloody red convex moist small long } \\
\text { pseudohyphae. }\end{array}$ & 0.015 \\
\hline \multicolumn{3}{|l|}{ Gram-negative (Enterics) } \\
\hline Enterdabater sakazakii & $\begin{array}{l}\text { LSA: Dull yellow, big convex, } \\
\text { mucoid } \\
\text { - Dull red with some yellow }\end{array}$ & 0.15 \\
\hline Citrobacter freandiz & $\begin{array}{l}\text { LSA: Yellow, yellow zone medium } \\
\text { raised }\end{array}$ & 0.013 \\
\hline $\begin{array}{l}\text { Enterdbacter agdomerans } 5(50 \%, \mathrm{API}) \\
\text { Lederia adecarboxylata (Biolog) }\end{array}$ & LSA: dull dark yellow & 0.004 \\
\hline Klingera spp. & Dull yellow small moist & 0.0002 \\
\hline Total percentage & & $72.5 \%$ \\
\hline
\end{tabular}

NF*: Non-fermenters.

Data shown in table 2 imply that identification of bacteria could not be related only to morphological characteristics especially color on R2A. As an example $P$. stutzeri showed a great variety in coloration on R2A from violet to brownish-orange to green and yellow. This diversity in coloration implies that there could be other subspecies for a specific strain that could be misidentified; this enhances the need of advanced systems for 
identification of environmental bacteria. In addition many bacteria could be morphologically similar but different upon identification as for Empeddbader bretis (Flawbacteriumbreze) and $P$. wesiaularis which showed yellowish-brown coloration on R2A.

As it is mentioned earlier, 13 gram-positive bacteria were isolated from the PRWST, and only one isolate couldn't be identified. All the isolates were identified using the Biolog system and some organisms could be identified according to their unique colony appearance on R2A or nutrient agar, for example Bacillus moxides isolated from the fiberglass tank $(2.10 \%$ out of $27.5 \%)$ showed a unique counterclockwise filamentous growth on agar (Fig. 18, left).

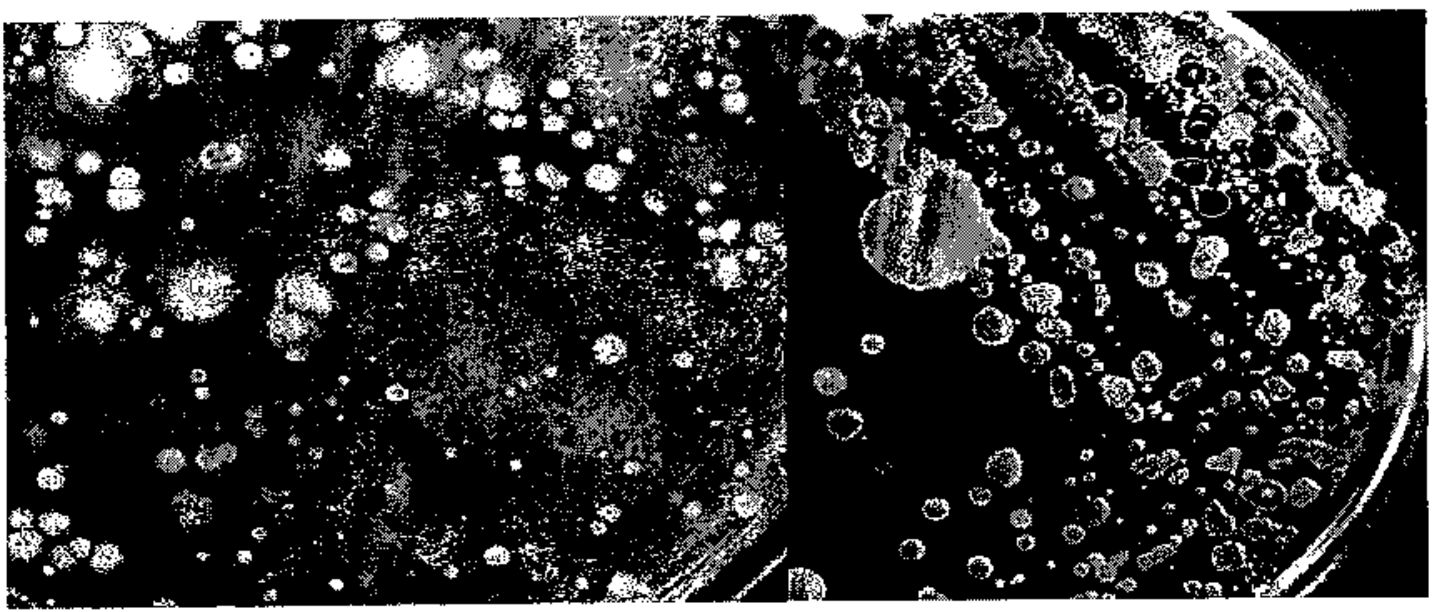

Figure 18: Left: Filamentous growth of Baallus myoodes, one of the few bacterial species which are identifiable by colony appearance. The "filaments" of $B$. moxodides always curve counter clockwise upon the surface of the agar. Right: Easily noted among the non-endospore-forming organisms on this particular plate is a red-pigmented strain of Streptomyces. (http://www.splammo.net/bact 102/home102.hml).

Bacillus spp. (aerobic endospore-formers) were predominant in the gram-positive bacteria. Data showed that out of $27.5 \%$ of all gram-positive bacteria, Bacillus spp. occurred about $17.5 \%$ with a predominance of $B$. ampldiquefaciens $9.63 \%$. In addition Artbrobader spp. showed the second most abundant genus with a percentage of $8.30 \%$.

On the other hand Bacillus showed variation in their color characteristic on $R_{2} A$ agar, such as $B$. amildiquefaciens varied from creamy white to creamy pink as well as some other Bacilli which varied form white to whitish green (Table 3). 
Table 3: Percentage occurrences of the gram positive bacteria isolated from the PRWST. Identification performed by the Biolog system.

\begin{tabular}{|c|c|c|}
\hline $\begin{array}{l}\text { Gram-positive bacteria } \\
\text { (Biolog) }\end{array}$ & Colony Description on $\mathrm{R} 2 \mathrm{~A}$ & $\begin{array}{l}\% \\
\text { Occurrence }\end{array}$ \\
\hline Bacillus amldiquefaciens & $\begin{array}{l}\text { - Creamy white + central spores } \\
\text { - Creamy pink + central spores }\end{array}$ & 9.63 \\
\hline Anthrdacter spp. & $\begin{array}{l}\text { Orange, medium moist rods, typical } \\
\text { coryneform (L and V forms) }\end{array}$ & 8.30 \\
\hline Bacillus spp. & $\begin{array}{l}\text { - Creamy white big flat central spores } \\
\text { - Whitish green moist flat bulgy } \\
\text { subterminal spores }\end{array}$ & 2.68 \\
\hline Bacillus pumilus & Yellow to orange dry, central spores & 2.30 \\
\hline B. moxoides & White brown flat moist curly spread & 2.10 \\
\hline $\begin{array}{l}\text { Congnebacterium liquefaciens } \\
\text { Brezibateritm - like }\end{array}$ & Mild yellow tiny short rods & 1.50 \\
\hline Bacillus baloderarss & $\begin{array}{l}\text { Pink to red shiny, convex tiny pigmented, dry } \\
\text { subterminal spores }\end{array}$ & 0.73 \\
\hline Staphylococuts dromogenes & Orange convex slimy cocci & 0.108 \\
\hline Bacillus subtilis & $\begin{array}{l}\text { Whitish yellow, medium flat, slimy rods + } \\
\text { central spores }\end{array}$ & 0.078 \\
\hline Staphilococas lentus & Red moist ratsed small & 0.049 \\
\hline n.i. (ER1000) & White big flat streptobacilli & 0.018 \\
\hline Brezibacterium casei: & Coccobacilli, white small & 01 \\
\hline A throbacter comminsit' & Whitish brown, flat & $<0.001$ \\
\hline Total percentage & & $27.5 \%$ \\
\hline
\end{tabular}

* Gram-positive bacteria that showed low percentage occurrence $<0.001 \%$ isolated from the cast iron and PE water storage tanks and identified using the Biolog system after 1 year of storage. 


\subsection{Microbiological Quality of the Influent drinking water}

Samples were also taken from the drinking water inlet carrying water to the PRWST. Data showed that $P$. deruginosa was found only in $29 \%$ (2 of 7) of the samples, total coliforms in $57 \%$ (4 of 7), and no fecal coliforms could be detected (Table 4). HPC bacteria were present in $33 \%$ of positive samples with concentrations ranging from $10^{2}$ to $10^{3} \mathrm{CFU} / \mathrm{mL}$ (Fig. 19).

$\%$ of positive samples

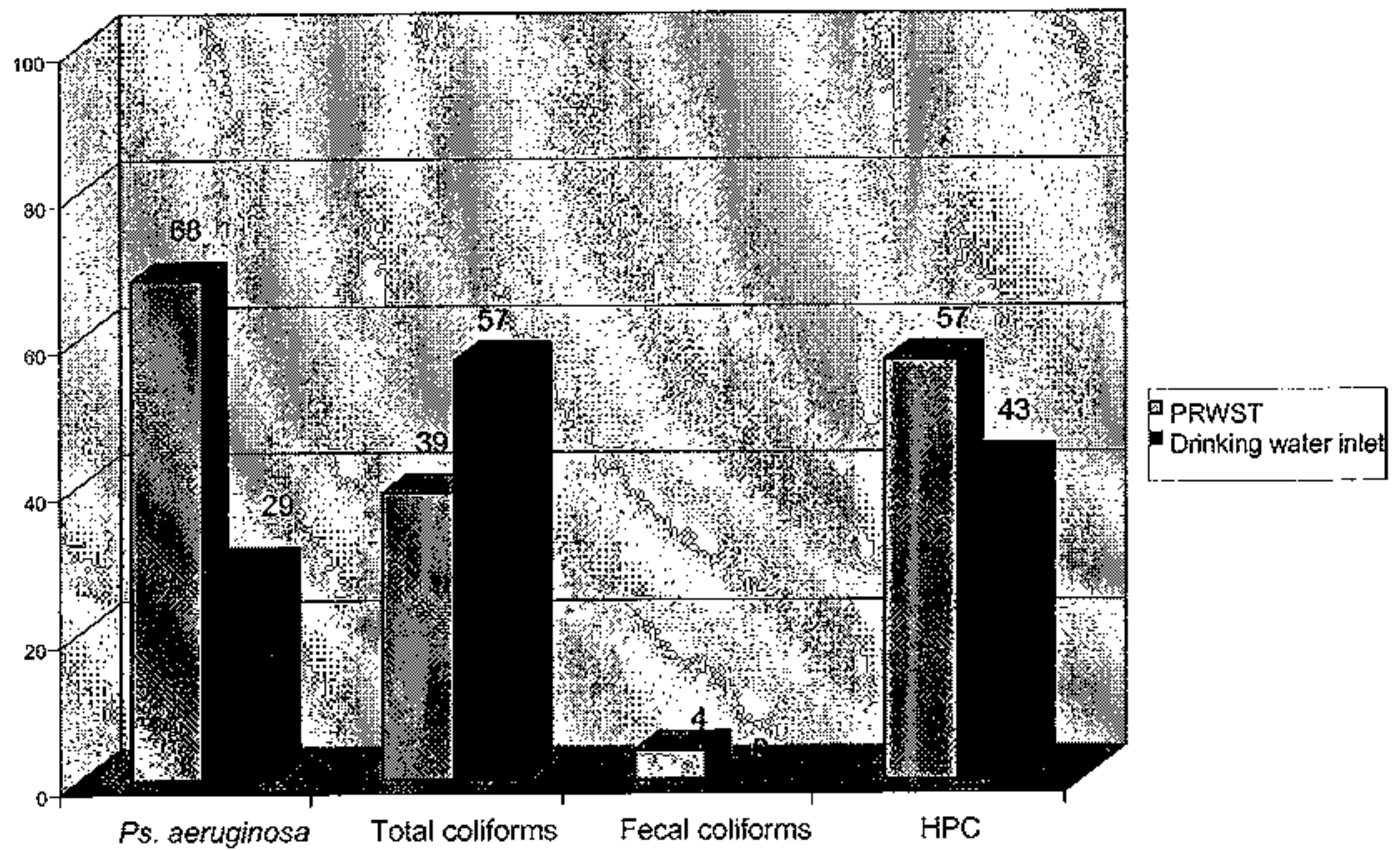

Figure 19: Percentage of samples positive for $P$. aenuginosa, total and fecal coliforms and heterotrophic plate count $(\mathrm{HPC})$ bacteria $(>500 \mathrm{CFU} / \mathrm{mL})$.

\subsubsection{Bacterial distribution in the Influent Drinking Water}

Up to 20 gram-negative bacterial isolates from the drinking water distribution system were collected. From the 20 isolates only one isolate $(5 \%)$ could not be identified using the API system. The predominant bacteria isolated were Pseudomonas spp. specifically Bumblodderia cepacia complex (5 of 7 samples) (Table 4). The predominant coliform bacteria were E. sakazakï (2/7) and to a lesser extent E. aggomerans $3(1 / 7$ samples) and Klorrera spp. (1/7) Furthermore Aeromonas sobria (1/7) and Pasterrella bxtemolytica (1/7) which are of public health concern were also isolated. 
Table 4: Number of occurrences (out of 7 runs) of the gram-negative and gram-positive bacteria isolated from the drinking water inlet.

\begin{tabular}{|c|c|}
\hline $\begin{array}{l}\text { Bacterial isolates } \\
\text { (Genus species subspecies) }\end{array}$ & $\begin{array}{l}\text { \# of occurrence } \\
\text { out of } 7 \text { runs }\end{array}$ \\
\hline \multicolumn{2}{|l|}{ Gram-negative } \\
\hline Buthbolderia cepacia (Ps. cepacia) & 5 \\
\hline Empedobader brezis (Flaw bacterium brece) & 3 \\
\hline P. dentiginasa & 2 \\
\hline Breumdimonas resioularis (Ps. zesicalaris) & 2 \\
\hline P. mesophilica & 2 \\
\hline "Enterobacter sakazakii & 2 \\
\hline A laligenes xylosoxydans xylosoxydans & 2 \\
\hline Agrabacterim radiobadter & 2 \\
\hline P. fluorescens & 1 \\
\hline P. stutzeri & 1 \\
\hline P. alcaligenes & 1 \\
\hline P. luteda & 1 \\
\hline n.i (API)-Pseudomonas spp.(Biolog) & 1 \\
\hline A eromonas solnia & 1 \\
\hline Pastemella hatemahtica & 1 \\
\hline Khorera spp. & 1 \\
\hline Splingononas multitorm & 1 \\
\hline A. salmonicida/ Odrobacteriumanthropi & 1 \\
\hline$*$ Enterdacter agdomerars 3 & 1 \\
\hline Omsochacterium meningoseptiam (Flawobacterium menimposeptioum) & 1 \\
\hline \multicolumn{2}{|l|}{ Gram-positive } \\
\hline Gondona terrae & 2 \\
\hline Bacillus amjloliquefaciens & 2 \\
\hline Artbrobacter spp. & 2 \\
\hline
\end{tabular}

* Total coliforms and their number of occurrences in the influent drinking water.

On the other hand, only 3 gram-positive bacteria Gordona terrae, B. ambldiquefaciens, and Arthrobacter spp. were isolated and occurred at the same percentages of $28.6 \%$ each $(2 / 7)$. Gordona terrae had an orange to red coloration on R2A agar (small, short diplobacilli). This low variety of gram-positive bacteria in the distribution system corresponding to the PRWST suggested that these bacteria were either dwelling in the tanks, in the sediments or biofilm, or were viable but not culturable in the inlet water and then bacterial regrowth has occurred in the tanks. 


\subsection{Physico-Chemical Parameters Results in the PRWST}

Results of the physico-chemical parameters are summarized in table 5. The temperature of the water varied from 14 to $30^{\circ} \mathrm{C}$. The lowest water temperature range in the tanks was in the winter period (December) whereas the highest temperature was in the summer (August), especially that all the tanks are totally exposed to the sun. The water temperature in the cast iron tanks was higher by 2 to $3 \circ \mathrm{C}$ than other tanks in the summer period with no significant variation in the winter season.

Table 5: Maximum, minimum and average values for the physico-chemical parameters in the PRWST.

\begin{tabular}{|l|l|l|l|}
\hline & Maximum & Minimum & Average \\
\hline Temperature $\left({ }^{\circ} \mathrm{C}\right)$ & 30 & 14 & 22 \\
\hline Free residual chlorine $(\mathrm{mg} / \mathrm{L})$ & 2.12 & 0.30 & 1.78 \\
\hline $\mathrm{gH}$ & 8.10 & 7.30 & 7.70 \\
\hline
\end{tabular}

Free residual chlorine was detected in all of the water samples with values ranging from 0.30 to $2.12 \mathrm{mg} / \mathrm{L}$, respectively. Turbidity was not measured in this experimental setup but accumulation of brown reddish sediments coming from the iron oxidizing bacteria in the cast iron distribution system was clearly seen in the Fiberglass tank especially during the period of intermittent supply of water. In addition, the fiberglass and the asbestos tanks had broken or unfitted covers allowing the accumulation of dust, large particles and organic materials from the decay of dead "animals"(like lizards and some smail reptiles).

\subsection{Effect of Retention Time (RT) on the Microbial Regrowth in the fiberglass tank}

The intermittent water supply applied in Byblos, implements storage of drinking water in roof water storage tanks in order to meet the consumers demand. This storage will enhance the bacterial growth leading to deterioration in the water quality and increasing the public health concern (Geldreich, 1996). To investigate the time effect of water storage in the roof tanks on the HPC and water quality, a simulation to what is actually happening during intermittent supply of water was performed on the fiber glass water storage tank. 
Two experiments were held during the months of April and May 2001; the fiberglass tank volume of $250 \mathrm{~L}$ was emptied and refilled before each experiment to reduce any external or internal interference which may cause undesired experimental effects. Each experimental run lasted 7 days and the water samples were collected at day 0 when the tank is full, day 2 , day 4 , and day 7 ; each time after sampling draining of 20,40 , and $80 \%$ of the tanks ${ }^{7}$ volume was performed respectively. This represents tentatively the human consumption per day on a period of one week.

During this experiment additional 2 samples at day 5 and day 6 were taken in order to specify the occurrence date of maximum HPC in the fiberglass tank. In addition water temperature was recorded using a digital thermometer (Electro-Therm, USA) before each sampling and samples were processed within one hour of collection.

Water was sampled from the tap at the bottom of the tank in sterile glass botties. Results show an increase in the HPC (CFU/mL) at day 4 and with maximum reached at day 5 remaining steady through day 7 (Fig. 20).

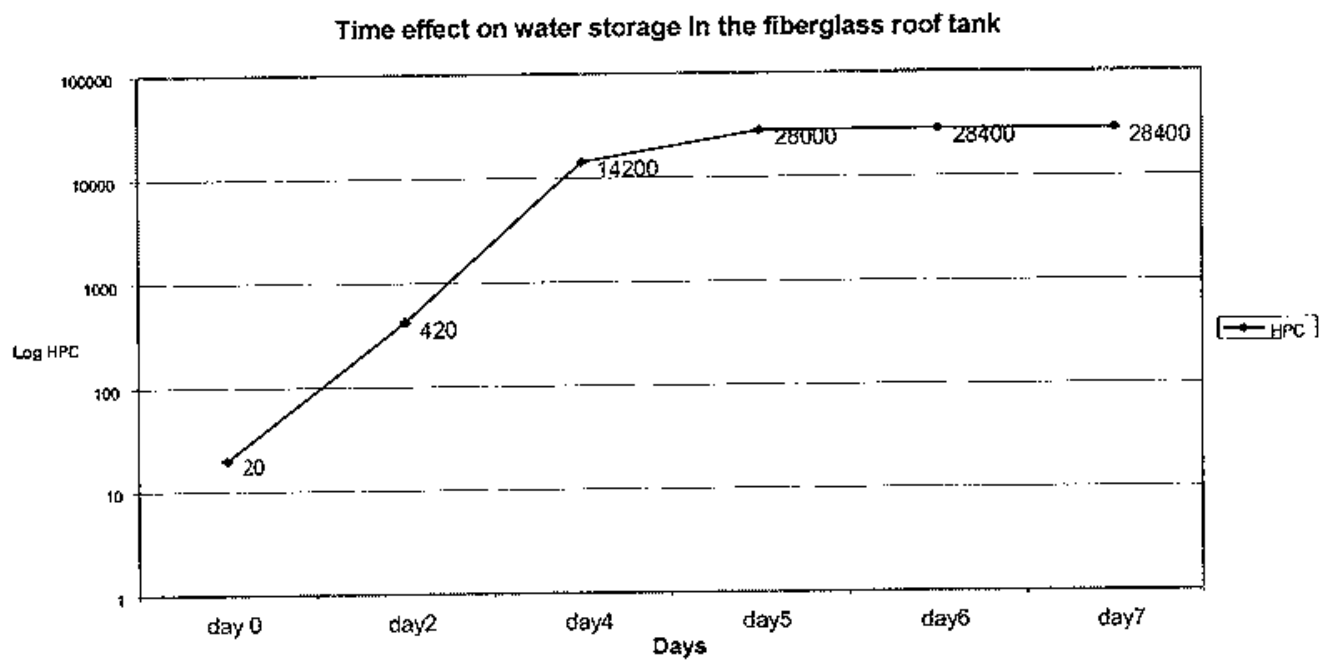

Figure 20: Log HPC vs. water storage time (days) in the Fiberglass tank

Data in the figure above showed that an exponential growth of HPC occurred from day 0 till day 4 after which a plateau phase was reached at day 5 till day 7 . 


\subsection{HPC levels in the UV Treated Water Tanks subjected to chlorination.}

HPC levels in the UV treated water were also determined in both types the PE and the cast iron tanks installed at LAU. These experiments were performed as control runs in order determine the HPC levels relative to water storage retention time on the same tanks that will be subjected to chlorination (Fig. 21).

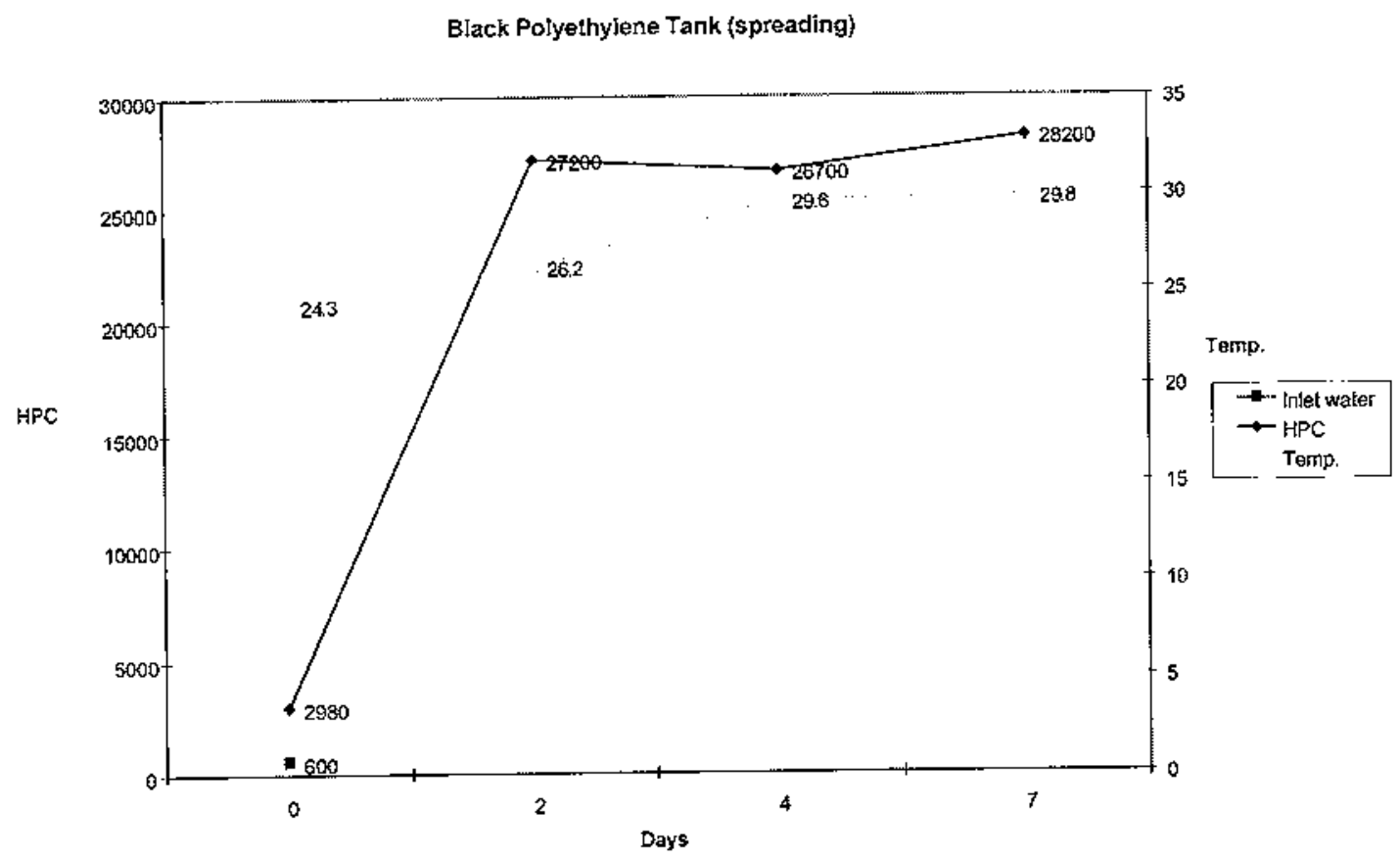

Figure 21: HPC vs. water storage time in the PE tank (chlorine experimental tank).

Results showed that after only 2 days of water storage more than 9 fold increase of HPC levels relative to day zero could be screened and after which the HPC levels was approximately steady till day 7 .

On the other hand the same experiment was performed on the water stored in the galvanized cast iron tank which will be subjected later to chlorination (Fig. 22). 


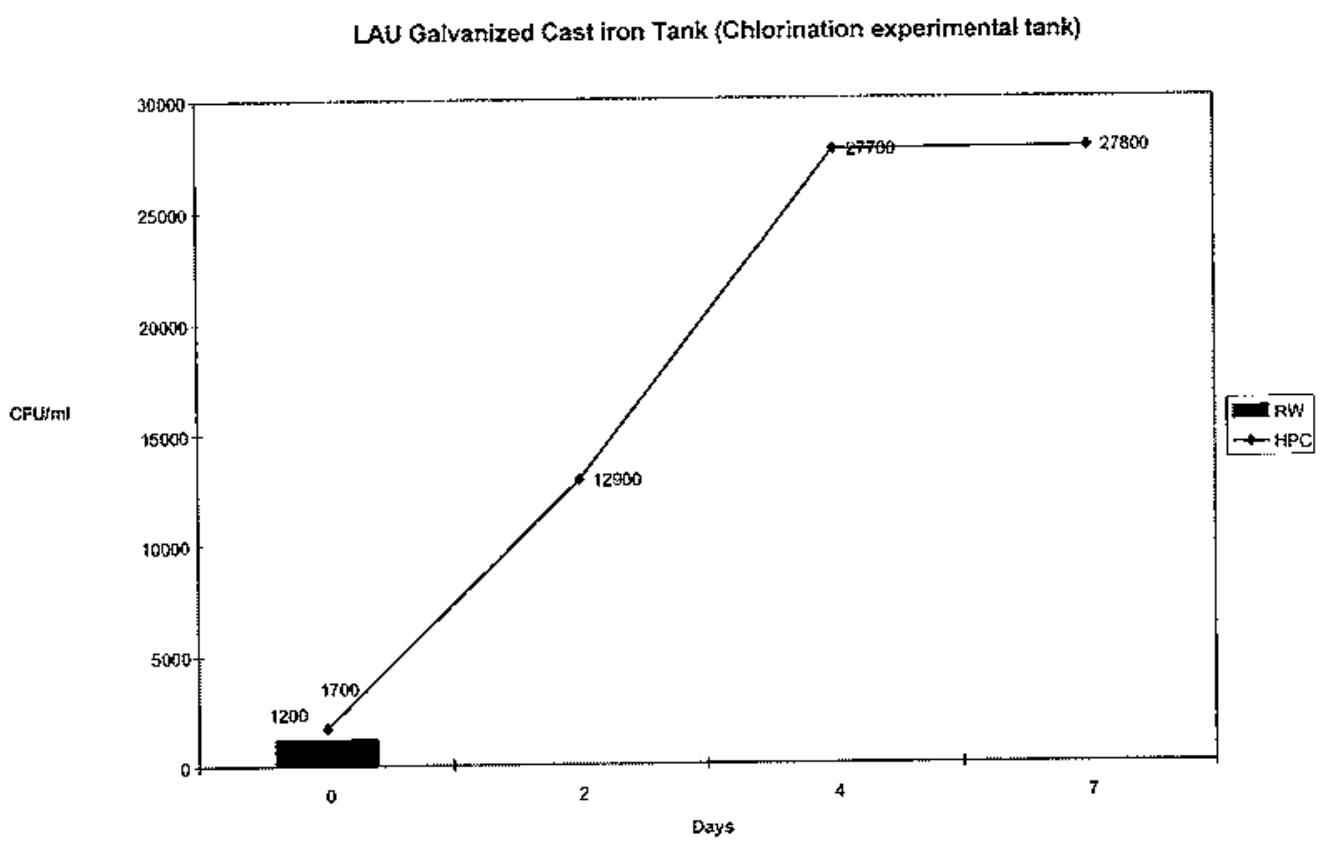

Figure 22: HPC vs. water storage time in the cast iron tank (chlorine experimental tantk).

Results showed that at day four a 16 fold increase of HPC (1700 to $27700 \mathrm{CFU} / \mathrm{mL}$ ) relative to day 0 could be monitored, after which counts was steady till day 7.

\subsection{Bacterial Population in the UV Treated Compared to the Chlorinated Water}

A comparison of the bacterial population isolated from the UV treated water (LAU, private well) to the chlorinated water (PRWST, city), was also held (Table 6).

Table 6: Bacterial population isolated from the water of PE taniss (PRWST \& LAC).

\begin{tabular}{|c|c|}
\hline $\begin{array}{l}\text { Bacterial isolates from the } \mathrm{PE} \text { tank in } \\
\text { the city (Chlorinated) }\end{array}$ & $\begin{array}{l}\text { Bacterial isolates from the PE tank at } \\
\text { LAU(UV) }\end{array}$ \\
\hline Obryseomonas luteda & A cinatdacter laoffii \\
\hline$P_{\text {s. fluorescenst? }}$ & A eromonas.salmmas. \\
\hline Ps.aentginasa & Comamonas testosteroni/ $P_{S}$ dicaligenes ${ }^{a}$ \\
\hline & Odmobacterium anthropi \\
\hline & Oigella wethralis \\
\hline & Pastemella spp. \\
\hline & Pseudomonas auregfaciens \\
\hline & Ps.fluorescenss: \\
\hline & Breumdimonas uesicularis \\
\hline
\end{tabular}




\begin{tabular}{|c|c|}
\hline & PS. blonoraphis \\
\hline & Ps.stutzen \\
\hline & Ps.alcaligenes \\
\hline & Sphingomonas paucimobilis \\
\hline & Vibrio metdmikoüi \\
\hline & n.i (P701do) \\
\hline Gram-positive Bacteria & Gram-positive Bacteria \\
\hline Arthrobater spp.* & Arthobacter spp.* \\
\hline Bacillus amblotiqueffaciens & Bacillus parmilus \\
\hline Brezibacterium casei & Staphlococous saprophytions \\
\hline
\end{tabular}

"represent bacteria in common in both treatment water systems.

a inability of the API $20 \mathrm{NE}$ database to distinguish between Comamonas testosteroni and $P$. alcaligens.

Table 6 shows that Pseudomonas finorescers is the only bacterium, from the gram-negative non-fermentative group, that could be isolated from both chlorinated and UV treated water, whereas Artbrobacter spp. and Bacillus spp. were common in the gram-positive bacteria. Three bacteria were of public health concern in the UV treated water, A eromonas spp., Pastemella spp. and Acinatobacter spp., in addition to $P$. aeruginasa isolated from the chlorinated water.

On the other hand a comparison of bacterial population isolated and identified from the water of the cast iron tanks at LAU and in the PRWST (city water) was also monitored (Table 7). 
Table 7: Bacterial population isolated from the water of the cast iron tanks (LAU \& PRWST).

\begin{tabular}{|c|c|}
\hline $\begin{array}{l}\text { Bacterial isolates from the cast iron tank } \\
\text { at LAU (UV) }\end{array}$ & $\begin{array}{l}\text { Bacterial isolates from the cast iron tank } \\
\text { in the city (chlorinated) }\end{array}$ \\
\hline A eromonas salmonicida mas. & Agrobacterium radiobacter \\
\hline Brezundimonas zesicudaris $\left(P_{S .}\right)$ & A eromonas sobria \\
\hline Commatronas testosteroni & A lcaligenes $x$ jlosarydans $x y l o s 0 x y d a n s$ \\
\hline Empedobacter bretis (F Larobacterium brew)" & 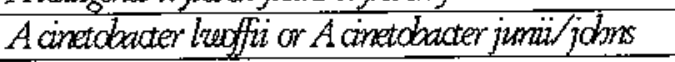 \\
\hline Oigella methralis & Bunkbolderia cepacia \\
\hline Pastermella spp.* & $C D C$ gr. IV C-2 \# dose to Bordetella \\
\hline Psendomonas aumedaciens & Enterdbacter sakazakit \\
\hline P. alcaligenes & Ereeinia spp. \\
\hline P. finorescen: & Flawbacterium fermuginam \\
\hline Sphingomonas paucimobilis: & Flawbauterium inddogenes \\
\hline Vibrio metsdmik outit & Empedobacter breris (Flawbacterium breze) * \\
\hline n.i \# non- fermentative $M 70100$ & Odmobacterium anthropi \\
\hline n.i \# non -fermentative M701fo & Pastemella baemalica \\
\hline Gram - positive & Pastennella spp." \\
\hline Bacillus amplatiguefaciens" & $P_{\text {seudomonas aenuginasa }}$ \\
\hline Bacillus halodwrans & P. putida \\
\hline Gordona nulonopertindus & P.pideettii \\
\hline Gordona terrae & P. fucrescen: \\
\hline Micrococous lateus & P. stutzeri \\
\hline Micrococas diverstus & P. fluorescens \\
\hline Staphlococas haemdytious & Pseudomonas spp. \\
\hline Staphlococas satprophytious & P. mesophilica \\
\hline Streptococous spp. & Sphingomonas paucimobilis: \\
\hline n.i rods $(\overrightarrow{P D} 7 \mathrm{a})$ & Weoksella imosa \\
\hline n.i rods (PDOb) & Lost by isolation (\# M8) \\
\hline & Gram - positive \\
\hline & Anthrobacter cormininsii \\
\hline & Anthrobacter spp. \\
\hline & Bacillus amidiquefaciens:" \\
\hline & Bacillus pumilus \\
\hline
\end{tabular}

" represent bacteria in common in both treatment water systems.

Psetdomonas spp. was the most abundant genus present in both treatment water systems. Four types of gram-negative non fermentative bacteria could be found in common, Empedobacter bretis (Flawblacterium brewe), Pastermella spp., P. fuorescens, and Sphingomonas paucimbilis. Furthermore only one type of gram-positive bacteria $B$. amglatiquefaciens was in common. 
Table 8: Bacterial population isolated from the inlet water (PRWST \& LAU).

\begin{tabular}{|c|c|}
\hline $\begin{array}{l}\text { Bacterial isolates from the inlet water } \\
\text { pouring into PRWST (chlorinated) }\end{array}$ & $\begin{array}{l}\text { Bacterial isolates from the inlet water } \\
\text { pouring into LAU tanks (UV) }\end{array}$ \\
\hline Breundimanas resicularis" & Breumdimonas resiculanis" \\
\hline P. alcaligenes" & P. alcaligenes" \\
\hline P. aeruginos $a$ & Omyseomanas luteda \\
\hline P. mescopilica & Psendomonas aurresfaciens \\
\hline P. stutzeri & Splingomonas pancimolilis \\
\hline \multicolumn{2}{|l|}{ P. fluonescens } \\
\hline \multicolumn{2}{|l|}{ Bumkhdderia apacia (P. cepacia) } \\
\hline \multicolumn{2}{|l|}{ P. linteda } \\
\hline \multicolumn{2}{|l|}{ Pseudommas spp. } \\
\hline \multicolumn{2}{|l|}{ Pasteumella batronditica } \\
\hline \multicolumn{2}{|l|}{ Khorera spp. } \\
\hline \multicolumn{2}{|l|}{ Sphingomonas multivonm } \\
\hline \multicolumn{2}{|l|}{ Enterdbader sakazakit } \\
\hline \multicolumn{2}{|l|}{ Alcaligenes xyloscoxydans xylosaxydans } \\
\hline \multicolumn{2}{|l|}{ A grobacterium radiobacter } \\
\hline Aeromonas salmonicida/ Odbrobactrum anthropich & A eromonas salmonicida /Odrobactrumanthropi ${ }^{*}$ \\
\hline \multicolumn{2}{|l|}{ Empeddacter brezis (Flawobacterium brene) } \\
\hline \multicolumn{2}{|l|}{$\begin{array}{l}\text { Chysedbacterium meningoseptiam (Flawbacterium } \\
\text { meringoseptiam) }\end{array}$} \\
\hline \multicolumn{2}{|l|}{ Aeromonds sobria } \\
\hline \multicolumn{2}{|l|}{ Enterdbater agdomerans 3} \\
\hline Gram -positive Bacteria & Gram-positive Bacteria \\
\hline Bacillus amplaliguefaciens & Gondona terrate \\
\hline Gondona terrae & Microocoxus lutets \\
\hline Anthrobacter spp. & \\
\hline
\end{tabular}

* represent bacteria in common in both treatment water systems.

a inability of the API $20 \mathrm{NE}$ database to distinguish between Aeromonas salmonicida and Odrobactrumanthopi.

In the inlet water only 3 bacteria belonging to the gram-negative non-fermentative type were in common. The genera in common were Psendomonas spp., Aerommas spp. and Brezumatimonas spp. Of public health concern A eromonas spp. as well as $P$. aeruginosa, as well as some bacteria belonging to the Enterobacteriaceae present in the influent chlorinated water. Whereas, it is shown that no coliforms could be detected in the inlet water in the UV treated water. On the other hand from the gram-positive bacteria only Gondonat terrae could be found in both systems. 


\subsection{Chlorination Effect on HPC in the Water of the PE \& Cast Iron Tanks (LAU)}

\subsubsection{First chlorination experiment: (PE tank)}

One chlorine tablet (Citernet(B) was pierced with a fine needle on 2 sides as shown in figure 8 and floated on the surface of the water in the tank and kept during all this experiment. Drainage of $20 \%$ of the tank after each sampling was performed and measurement of $\mathrm{Cl}_{2}$ concentration and temperature were also recorded. In this experiment dissolution of $\mathrm{Cl}_{2}$ was fast and high, due to the wide pore size in the chlorine tablet, so that after only 0.06 days $\left(90 \mathrm{~min}\right.$ ), with free $\mathrm{Cl}_{2}$ concentration reaching $0.11 \mathrm{mg} / \mathrm{L}$. After one day it reached $4 \mathrm{mg} / \mathrm{L}$ (Fig. 23).

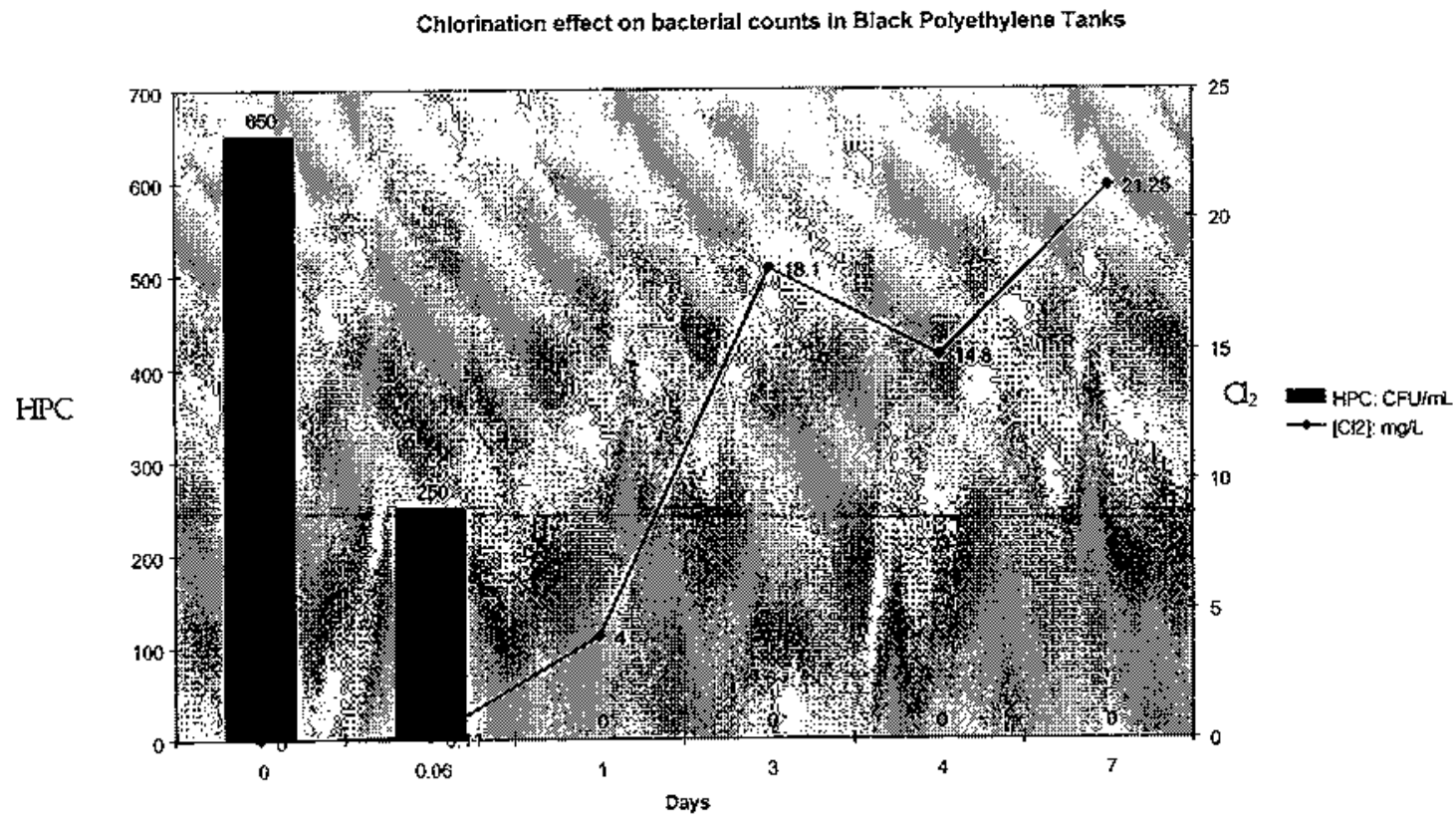

Fig. 23: $\mathrm{HPC}$ vs. $\left[\mathrm{Cl}_{2}\right]$ vs. water storage time in the $\mathrm{PE}$ tank $\left(1^{\mathrm{st}} \mathrm{run}\right)$.

At day $O$ the PE tank installed at LAU was full with fresh water, day 0 is considered as the inlet water coming through the distribution system, which had an HPC level of 650 $\mathrm{CFU} / \mathrm{mL}$. After 0.06 days $(90 \mathrm{~min}$ ) of dissolved chlorine contact time in the water, a 2.6 times decrease in HPC levels had occurred, and after only 1 day HPC could not be detected as shown in figure 23 . 


\subsubsection{Second chlorination experiment: (PE tank)}

A second chlorination run was performed where the same polyethylene tank was washed and drained with the inlet water several times in order to remove any residual chlorine in the tank. In this experiment a fine needle pin was used by which $\mathrm{Cl}_{2}$ dissolution was more controlled. Data showed that a drastically decrease of $\mathrm{HPC}_{\text {, a }} 271$ fold decrease occurred, at a free chlorine concentration of $0.11 \mathrm{mg} / \mathrm{L}$ (Fig. 24). Temperature ranges from $28^{\circ} \mathrm{C}$ at day 0 to $32^{\circ} \mathrm{C}$ at day 7 .

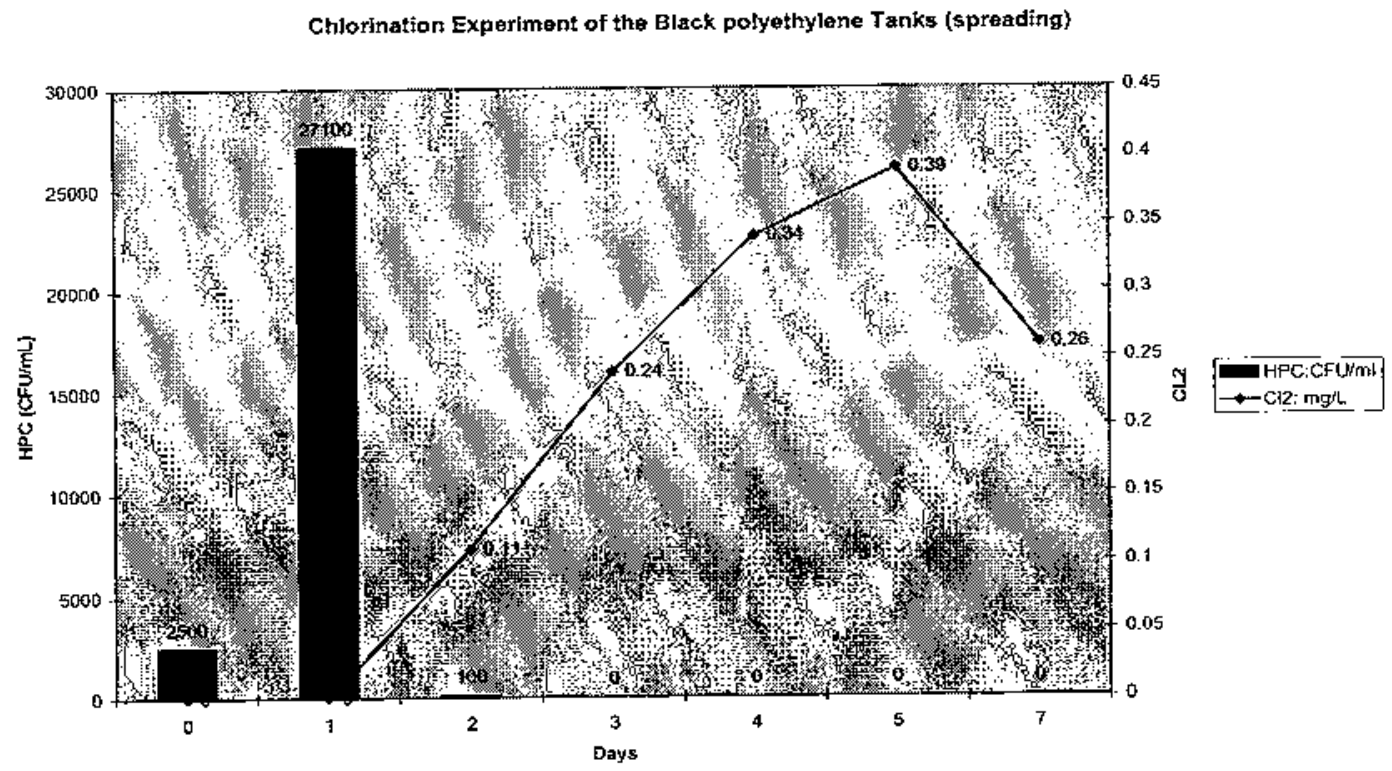

Figure 24: Effect of $\left[\mathrm{Cl}_{2}\right]$ levels on $\mathrm{HPC}$ in the PE water storage tank $\left(2^{\text {nd }}\right.$ run).

This very high count $(27100 \mathrm{CFU} / \mathrm{mL})$ that occurred at day 1 could be specific to the chlorinated polyethylene tank used. Free chlorine fluctuated from $0.11 \mathrm{mg} / \mathrm{L}$ at day 2 to $0.26 \mathrm{mg} / \mathrm{L}$ at day 7 . The bacterium that survived chlorination (free $\mathrm{Cl}_{2}=0.11 \mathrm{mg} / \mathrm{L}$ ) at day 2 is Commebacterium zariabilis (Casedacter polymorphis). The morphological characteristics on $\mathrm{R} 2 \mathrm{~A}$ of this bacterium were white, raised and small.

On the other hand, and at the same time and the same experimental conditions water samples were taken and processed from a control polyethylene tank and comparison of HPC vs. time were recorded as shown in figure 25. 


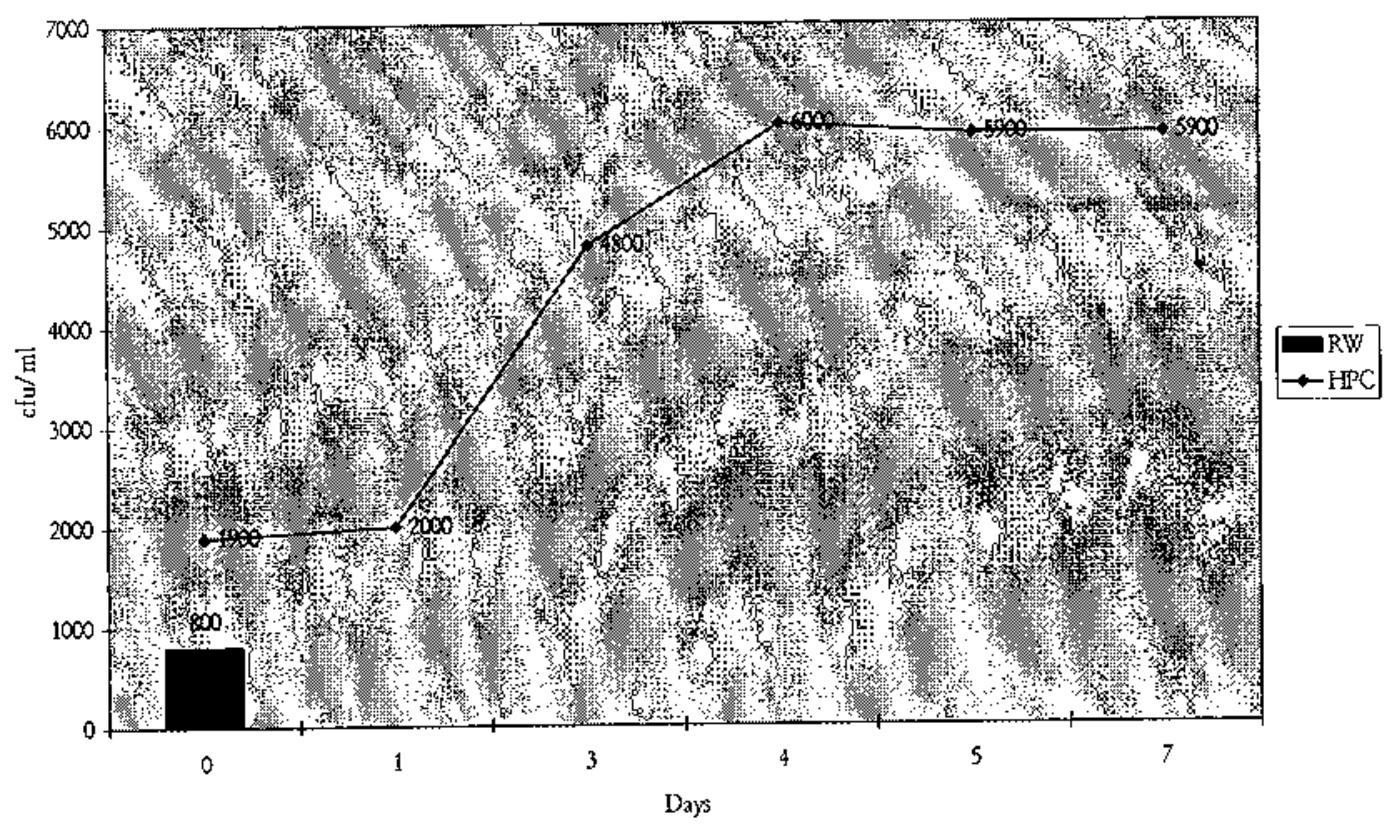

Figure 25: HPCvs, water storage time in the control PE tank ( $2^{\text {nd }}$ run).

Results showed that more than 3 fold increase $(-3.2)$ of $\mathrm{HPC} / \mathrm{mL}$ occurred at day 4 as compared to day 0 and kept constant till day 7. In addition it was clearly seen that the HPC in the control tank at day 1 was about 13 times less than the chlorinated experimental tank, and this could be a tank specific factor, as for sediments and biofilm in such tank, since experiment was held under the same conditions.

\subsubsection{Reverse mechanism of chlorination}

In this experiment the chlorinated PE tank was used where free chlorine reached 0.51 $\mathrm{mg} / \mathrm{L}$ after 9 days and then diluted with inlet water to reach a free chlorine concentration of $0.25 \mathrm{mg} / \mathrm{L}$. A reverse mechanism to the previous experiment was performed where day 7 is considered as day 0 in this experiment; the chlorine tablet was removed at day 0 and then refilling of $20 \%$ of water after each sampling. The aim behind this experiment was to monitor the effect of the residual chlorine decrease as compared to the HPC increase relative to time in the water tanks (Fig. 26). 


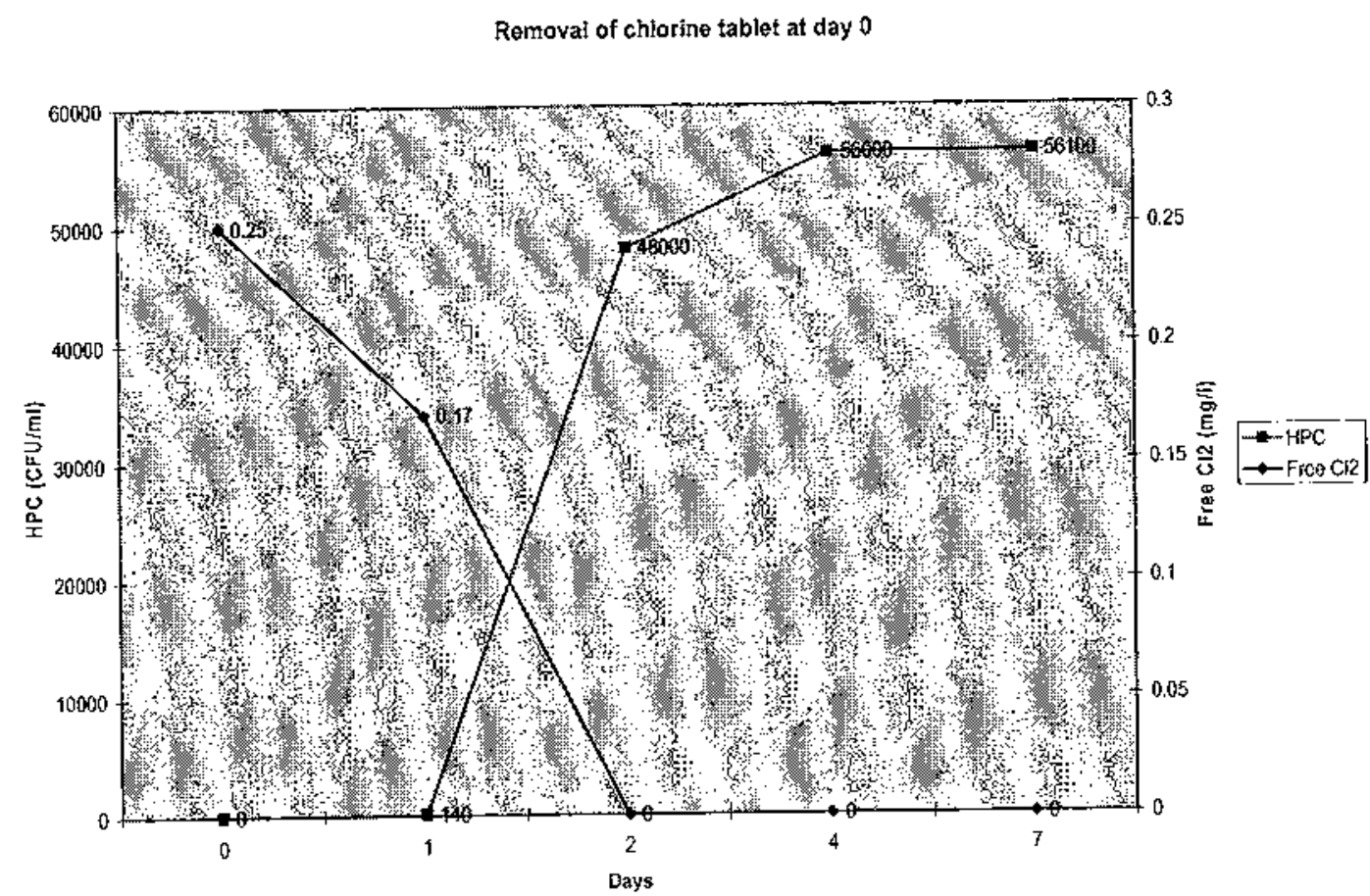

Figure 26: Reverse mechanism of water chlorination: $\mathrm{HPC}$ vs. $\left[\mathrm{Cl}_{2}\right]$ vs. water storage time in the PE tank.

Results showed that after only 2 days free chlorine decreased from $0.25 \mathrm{mg} / \mathrm{L}$ to $0 \mathrm{mg} / \mathrm{L}$ and $\mathrm{HPC}$ increased from $0 \mathrm{CFU} / \mathrm{mL}$ to $48000 \mathrm{CFU} / \mathrm{mL}$, bacterial regrowth occurred, and HPC levels reached a plateau phase at day 4 till day 7 . The HPC levels increased 1.16 times even after $\left[\mathrm{C}_{2}\right]$ dropped to zero between day 2 and day 7 of water storage time suggesting reoccurrence of bacterial regrowth.

\subsubsection{Third chlorination experiment: (PE tank)}

During October the same chlorination experiment was performed. It was noticed that when the $\mathrm{C}_{2}$ level reached $0.10 \mathrm{mg} / \mathrm{L}$ the HPC count level dropped to zero. From day 1 till day 5 free $\mathrm{Cl}_{2}$ fluctuated from 0.10 to $0.14 \mathrm{mg} / \mathrm{L}$ and $\mathrm{HPC}$ remained $0 \mathrm{CFU} / \mathrm{mL}$. But at day 6 and day 7 when free $\mathrm{Cl}_{2}$ dropped to 0.08 and $0.05 \mathrm{mg} / \mathrm{L}$ respectively, $\mathrm{HPC}$ raised to 100 and $130 \mathrm{CFU} / \mathrm{mL}$ (Fig. 27). 


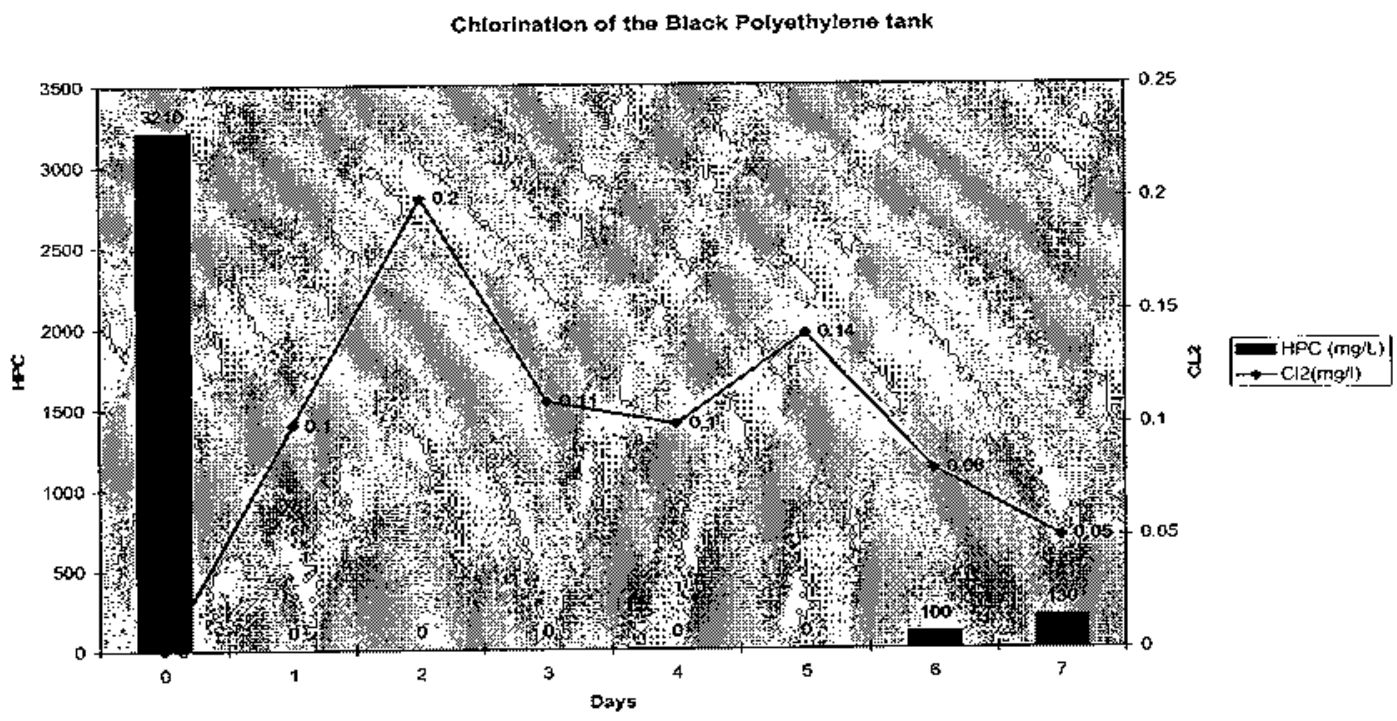

Figure 27: $\mathrm{HPC}$ vs. $\left[\mathrm{C}_{2}\right]$ vs. water storage time in the $\mathrm{PE} \operatorname{tank}\left(3^{\text {rd }} \mathrm{run}\right)$.

Furthermore $\mathrm{HPC} / \mathrm{mL}$ levels were determined in the control PE tank relative to time and at the same experimental conditions as of the chlorinated tank. The highest count was reached after 4 days of storage $(9400 \mathrm{CFU} / \mathrm{mL})$ after which a plateau phase was reached till day 7 (Fig. 28).

Control polyethylene tank

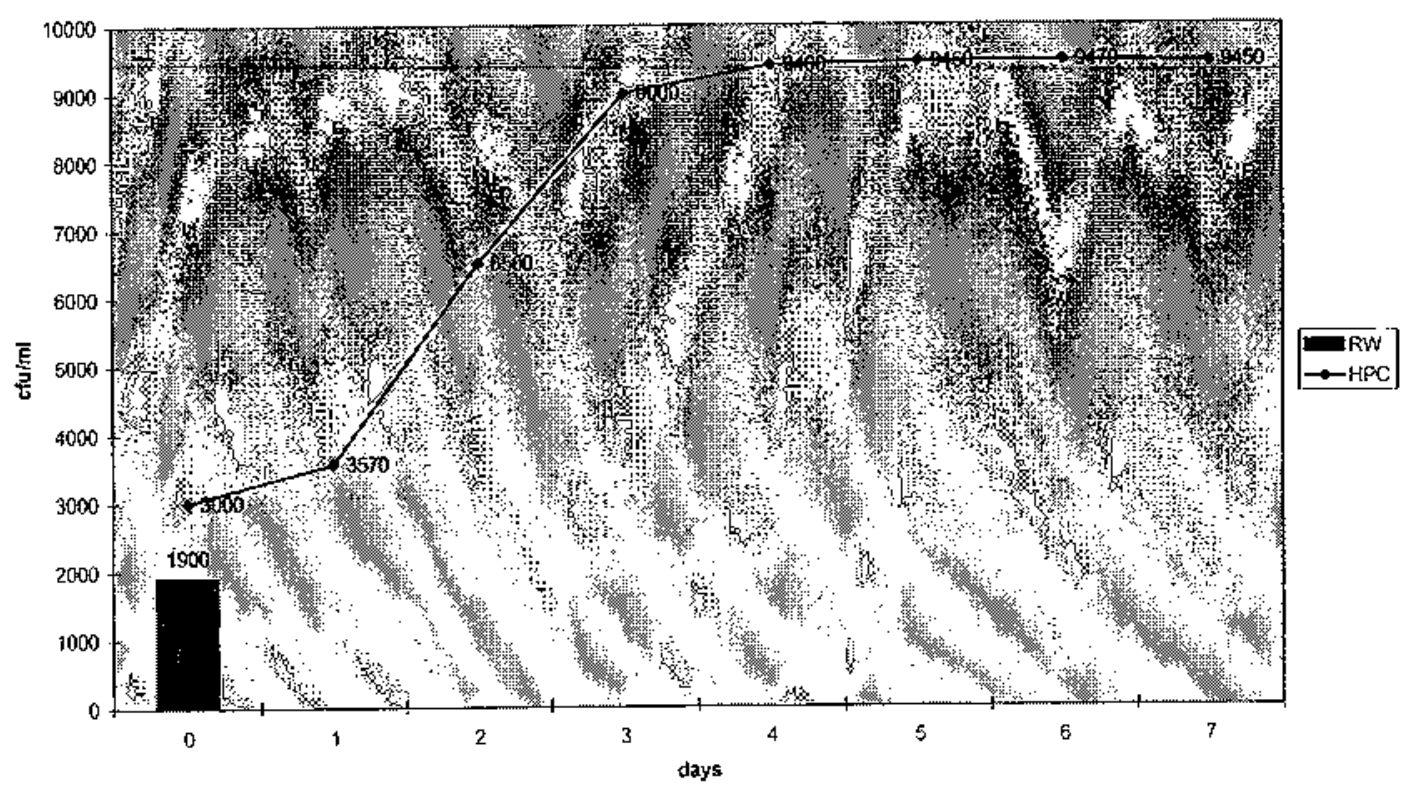

Figure 28: $\mathrm{HPC}$ vs. water storage time in the control PE tank $\left(3^{\text {rd }}\right.$ run). 


\subsubsection{Chlorination runs on the water stored in the cast iron tank}

Chlorination run was also performed on the cast iron tank. In this run the free chlorine concentration reached $0.35 \mathrm{mg} / \mathrm{L}$ at day 0 where the tank is completely full, after which the chlorine tablet was removed (Fig. 29). Free chlorine fluctuated from $0.35 \mathrm{mg} / \mathrm{L}$ at day 0 to $0.06 \mathrm{mg} / \mathrm{L}$ at day 7 and $\mathrm{HPC}$ respectively from $0 \mathrm{CFU} / \mathrm{mL}$ to $120 \mathrm{CFU} / \mathrm{mL}$. Contradictory to the PE tank even at a free chlorine concentration of $0.26 \mathrm{mg} / \mathrm{L}$ and 0.19 $\mathrm{mg} / \mathrm{L}, \mathrm{HPC}$ levels were 7 and $50 \mathrm{CFU} / \mathrm{mL}$ respectively.

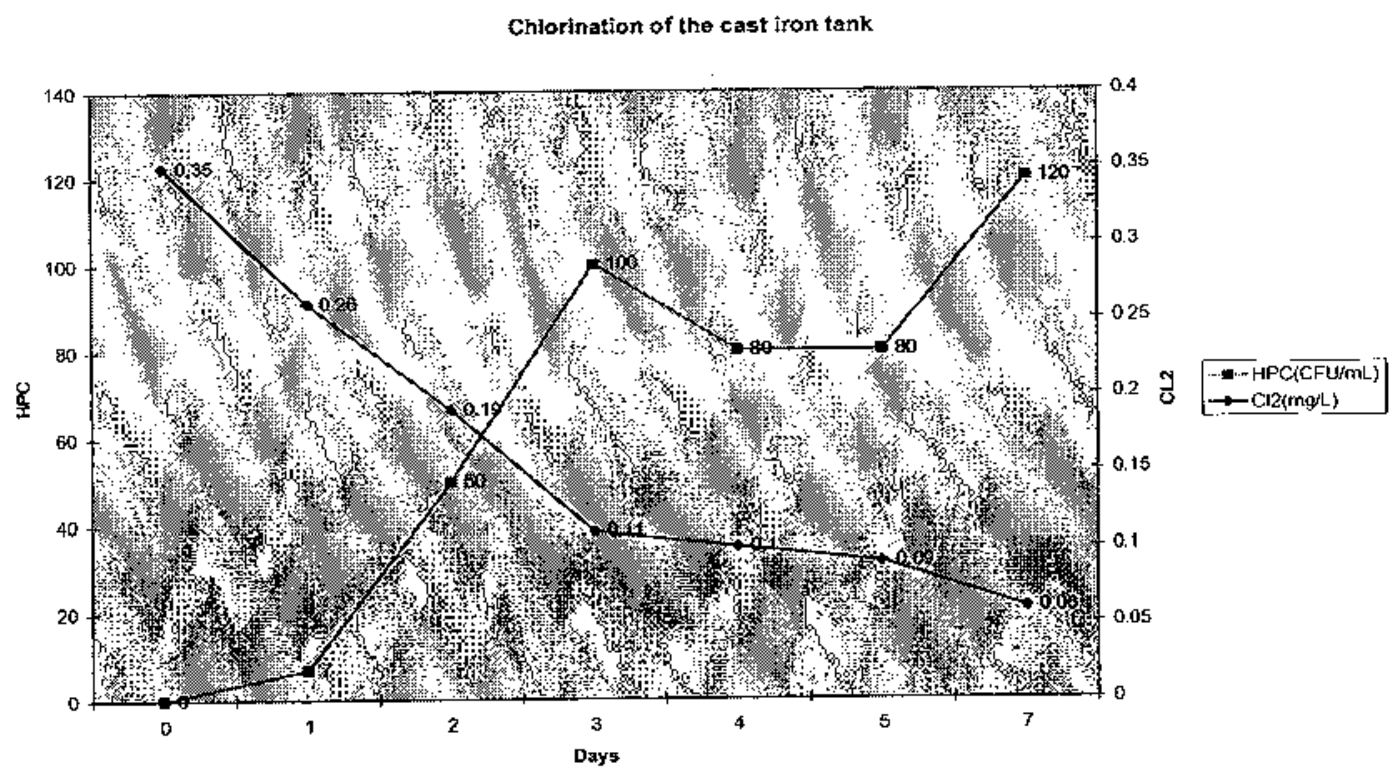

Figure 29: $\mathrm{HPC} v$ s. $\left[\mathrm{Cl}_{2}\right]$ vs. water storage time in the cast iron tank.

The bacterium that survived free chlorine of $0.26 \mathrm{mg} / \mathrm{L}$ was of one type; its characteristic on $R_{2} \mathrm{~A}$ agar is green, mediun size, gram-negative rod, but it couldn't be identified. Whereas at lower free chlorine levels gram-positive aerobic endospore forming Bacilli predominates, in addition to Staphylooxcus saprophytious, which survived a free residual chlorine of $0.19 \mathrm{mg} / \mathrm{L}$ (Table 9). Bacillus spp. were of 2 types and their characteristics ranged from long to medium rods, and yellow or brown, and spores central to subterminal bulgy. In addition to the following Gondona mibropertintus a gram-positive bacterium, its morphological appearance is red to orange moist on $\mathrm{R}_{2} \mathrm{~A}$, survived lower chlorination levels of $0.09 \mathrm{mg} / \mathrm{L}$ and $0.06 \mathrm{mg} / \mathrm{L}$ at day 5 and day 7. 
Table 9: Bacterial poptuation in the chlorinated water of the galvanized cast iron tank

\begin{tabular}{|c|c|c|c|c|}
\hline Days & $\begin{array}{l}\text { Free residual } \\
\text { chlorine } \\
(\mathrm{mg} / \mathrm{L})\end{array}$ & $\begin{array}{l}\mathrm{HPC} \\
(\mathrm{CFU} / \mathrm{mL})\end{array}$ & Isolated Bacteria & $\begin{array}{l}\text { Characteristics } \\
\text { on R2A }\end{array}$ \\
\hline 1 & 0.26 & 7 & $\begin{array}{l}\text { Unidentified gram-negative } \\
\text { (slightly gram-positive) curved } \\
\text { shape rods (Non- } \\
\text { fermentative). Suspected to be } \\
\text { one of the fast growing NTM } \\
\text { Myoblotuterimspp. }\end{array}$ & $\begin{array}{l}\text { Pigmented } \\
\text { green, medium }\end{array}$ \\
\hline 2 & 0.19 & 50 & 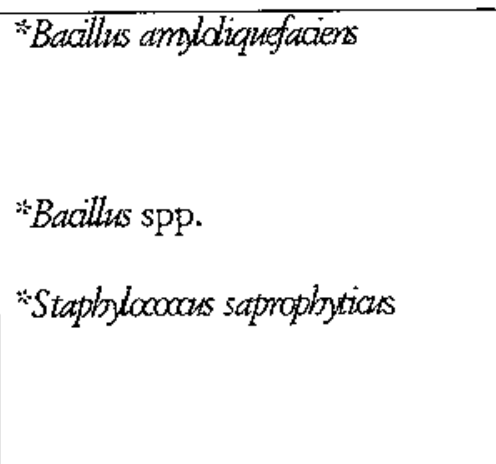 & $\begin{array}{l}\text { "brown, medium } \\
\text { rods, central } \\
\text { spores } \\
* \text { yellow, long } \\
\text { rods, subterminal } \\
\text { spores } \\
* \text { golden brown } \\
\text { raised }\end{array}$ \\
\hline 3 & 0.11 & 100 & same types as day 2 & \\
\hline 4 & 0.10 & 80 & same types as day 2 & \\
\hline 5 & 0.09 & 80 & $\begin{array}{l}\text { Same types as day } 2 \text { plus } \\
\text { *Gondona nubropentinatus }\end{array}$ & $\begin{array}{l}\text { red to orange, } \\
\text { short rods }\end{array}$ \\
\hline 7 & 0.06 & 120 & Same types as day 5 & \\
\hline
\end{tabular}

It was shown in (table 9) that five bacterial strains survived chlorination run in the cast iron tank. Only one bacterium (20\%) belonged to the gram-negative non fermentative rods survived free residual chlorine of $0.26 \mathrm{mg} / \mathrm{L}$ which could not be identified by any identification systems used in this study. The other 4 bacteria ( $80 \%)$ were part of various gram-positive bacteria. 


\subsection{Microbial Identification Systems the Biolog vs. the API}

Identities assigned to the randomly selected 57 gram-negative isolates recovered from the drinking influent water and the household water storage tanks are shown in Table 10 (For details see Appendix table 1). The Biolog system assigned identities to $52(91.2 \%)$ gram-negative organisms tested and the API identified $47(82.5 \%)$. The percentage of isolates that were assigned the same identity (genus \& species) by both systems was $24.6 \%$ (14 of 57). Moreover 33.3\% (19 of 57) were not similar at the genus level, while $15.8 \%$ ( 9 of 57 ) were not similar at the species level. However, $89 \%$ of the gram-positive bacterial isolates were identified using the Biolog system.

Identification of 31 isolates ( $\sim 53 \%$ of all tested gram-negative organisms) belonging to Pseudomonas however, revealed better agreement in the results at both the genus and species level. The percentage of isolates that were assigned the same identity by both systems was $45.2 \%$ (14 of 31 ). Differences were seen between both systems, where $9.68 \%$ and $35.5 \%$ of the isolates using the API were assigned to different species or genera, respectively. However, $6.45 \%$ were identified as Psetdomonas by the Biolog and not identified by the API, and $3.22 \%$ were identified as Psendomonas by the API and not identified by the Biolog.

Furthermore among the total identified gram-negative bacteria only 3 isolates belonged to the coliform group. These 3 isolates were of 2 genera Citrobater and Enterobater, both systems showed $100 \%$ similarity at the genus level, and no similarities at the species level (Table 10). 
Table 10: Identification of bacterial strains according to Biolog GN and API-20NE and API$20 \mathrm{E}$ for $24 \mathrm{~h}$ incubation ${ }^{2}$

\begin{tabular}{|c|c|c|}
\hline No. of Isolates & Biolog Identification & API Identification \\
\hline$\overline{2}$ & Adromabacter dsolinophagum & No ID \\
\hline 1 & A cidowrax delafieldii & P. alcaligenes \\
\hline 1 & A cintothacter genospecies 11 & P. copacia (B. cepacia) \\
\hline 1 & A eromonas zeronii/solnia DNA go 8 & Odrobactrumanthropi \\
\hline 1 & Aquaspinillsm dispar & No ID \\
\hline 1 & Bretumatimonas wesiculanis & P. zesioularis (B. resculatris) \\
\hline 2 & Butkbolderia cocournenans & A cinatdacter leoffi \\
\hline 1 & Bukbldderia oxcounenans & No ID \\
\hline 1 & Bumbolderia rietnamensis & Sphingobacterium multizonm \\
\hline 1 & Citrohader braakï & Citrobacter fremendii \\
\hline 1 & Enterdxacter doacae & Enterdbater sakazakü \\
\hline 1 & Enterdhater gergoriade & Enterdbacterspp. \\
\hline 1 & Erainia carotorora ss betanasculonm & No ID \\
\hline 1 & Flavbacterim fermiginerm & No ID \\
\hline$\overline{1}$ & Flawobadterimiolonsonide & Splbingomonas paucimblitis \\
\hline 1 & Moraxella coloensis & Weeksella rimosa \\
\hline 1 & Pastemella trehalosi & Flawbadteriam breze \\
\hline 2 & Pastemella trehalosi & Pastemella hatembitica \\
\hline 1 & Pastemella preumotropica & Pastemella haemblytica \\
\hline 1 & No ID [Pshydrobacter phendpynaious $]^{2}$ & P. dblororaphis \\
\hline 3 & P. aenginosa & P. aentiginasa \\
\hline 2 & P. alcaligenes & P. alcaligenes \\
\hline 1 & P. citronelldis & A lcaligenes fecalis \\
\hline 1 & P. fluorescens & Woeksella inosa \\
\hline 1 & P. fluonescens & A lcaligenes fecalis \\
\hline 1 & P. fluorescens & No ID [Agrobacterium radiobacter $]^{*}$ \\
\hline 1 & P. fluorescens Biotype $A$ & P. fluorescens \\
\hline
\end{tabular}




\begin{tabular}{|c|c|c|}
\hline 1 & Pseudomonas sp. $[P \text {. fuorescens BiotypeF }]^{a}$ & No ID \\
\hline$\overline{1}$ & P. merdocina & Splingobacterium multivonm \\
\hline 1 & P.psendoalcaligenes & P. stutzent \\
\hline 1 & P. putida Biotype A & P.putida \\
\hline 1 & P. putida $[P \text {. putida Biotype } \mathrm{A}]^{\mathrm{a}}$ & No ID \\
\hline 1 & Psendomonas spp. & {$\left[{\text { [Pseudomonas spp. }]^{b}}^{b}\right.$} \\
\hline 5 & P. stutzent & P. stutzeni \\
\hline 1 & P. syrxantha & Ervinia spp. \\
\hline 2 & P. symaantha & P. fluonescens \\
\hline 1 & No ID [Vibrio harayg] & P. mespophilica \\
\hline 1 & Vilmo motsdmikouii & No ID \\
\hline$\overline{1}$ & Vikno tubiashiz & P. resicularis \\
\hline 1 & Vibrio tubiashii & No ID \\
\hline 1 & No ID [Vibrio tubiashii] ${ }^{2}$ & Aeromonas solvia \\
\hline$\overline{1}$ & No ID & No ID [Agrobacterium radiobacter ${ }^{\mathrm{n}}$ \\
\hline 1 & No ID & P. resizularis \\
\hline 1 & $\overline{N o} \mathrm{ID}$ & Flawdbacterim brete \\
\hline 1 & No ID & Flawobadterium inddogenes \\
\hline 1 & No ID & A latigenes xylosaxydans xyloscoxydans \\
\hline
\end{tabular}

" In brackets are shown $48 \mathrm{~h}$ or more designations if different from $24 \mathrm{~h}$ results. Biolog GN identification is acceptable if the similarity index $\geq 0.5$. API-2ONE \& $20 \mathrm{E}$ identification is considered acceptable if the level of certainty is equal to or greater than $80 \%$.

${ }^{b}$ Identified as $P$. pickettii $31.0 \%, P$. funescens $29.0 \%$, and P. Cllororaphis $21.0 \%$. 
Cbapter 5

\section{DISCUSSION}

\subsection{Introduction}

This report aims to obtain a better understanding of the microbial population present in different water storage tanks as well as in the drinking water inlet. This will lead finally to better public health standards and will increase our conceptual understanding of the drirking water environment.

\subsection{HPC levels variation in the PRWST}

This study indicates that providing water to residences with residual chlorine has a significant effect on the water quality in the PRWST, but it is not enough to prevent deterioration of its bacteriological quality, since many other factors may play a role in such proces. During the months of July, August, and September (2000) a maximum demand by the building residents on water from tanks, and low water supply at this summer time of the year, lead to an increase of mixing of freshly chlorinated inlet water with the stored water. Thus an increase of free chlonine in the water of the tanks had drastically decreased the $\mathrm{HPC}$ to less than $200 \mathrm{CFU} / \mathrm{mL}$ in all tanks. Other factors like turbidity, and residence time had less significant effect in these months.

Whereas, in the winter season starting in October, November and remartably in December, low demand on water in the tanks by the residents had lead to a decrease of mixing with freshly chlorinated water influent. Thus high residence time of water stored in the tanks as well as mild decrease of free chlorine in the water inlet resulted in an increase of HPC from $5 \mathrm{CFU} / \mathrm{mL}$ in July to $4 \times 10^{4} \mathrm{CFU} / \mathrm{mL}$ in December in all tanks. This finding is supported by literature where Tokajian and Hashwa (2003) showed that higher turbidity values were detected during the winter as compared to the summer in the network system in a residential area in Beirut, Lebanon. This may be due to sand erosions in the source water, especially in the shallow aquifers, following periods of heavy rainfall resulted in high 
turbidity that correlated with the higher counts in storage tanks. Higher counts are often the results of bacterial regrowth, particularly in distribution systems and storage water tanks. HPC bacteria are capable of surviving on minimal nutrients, attach to pipe sediments, and participate in the biofilm formation (Geldreich, 1996). Furthermore, high turbidity in the winter, in the distribution system could also have a negative effect on chlorination thus an increase in bacterial counts. The United States Environmental Protection Agency (USEPA) recommends that HPC bacteria should not exceed $500 \mathrm{CFU} / \mathrm{mL}$ in drinking water in order to reduce interference with the detection of coliform bacteria (EPA, 1986).

On the other hand, this study indicated no difference in the bacterial growth (HPC) potential between the different experimental tanks' type either if the water tanks have the same (PE and cast iron tanks at LAU) or different sizes (PRWST). This finding is in contrast to what is stated in literature where, the kind of lining of the reservoirs walls was found to effect the potential growth of bacteria in the water tanks by leaching organic materials unto the water that supports bacterial growth (Eligas \& Lee, 1980).

\subsection{Gram-negative bacteria in the PRWST}

In this study Pseudomonas spp. were the major gram-negative non-fermentative types with predominance of $P$. aerriginox $(26.2 \%)$ which poses a public health hazard as significant opportunistic pathogen. This finding is in accordance to what is stated in the literature that Pseudomonadaceae constitute a large fraction of the bacteria found in natural waters and they can often be isolated from drinking water (van der Kooij, 1977). This increase is supported by many other studies, which found that genera like Pseudomonas, Flawbaderia and pigmented bacteria in general can recover, grow and multiply in stagnant oligotrophic water (Geldreich, 1996).

Additionally Breumdimonas resicularis which had a low percentage occurrence of $1.75 \%$ in the storage tanks was found to be the dominant species in a previous study conducted in the U.K (Gibbs at al., 1990). However, this species as weil other HPC types are suggested to be indigenous (natural) water microbiota and do not have public health hazard. The bacterial species found in this study (except $P$. aeniginasa and few other genera) were 
similar to those found in other areas of the world, with some differences in the percentages of occurrence. For example, in Cambridgeshire, UK, P. fuorescens, Alatigenes spp., and Aeromonas spp. were the dominant species isolated from R2A medium (Sunna-Borgan, 1998).

Among the coliform group isolated, E. sakazakü was the predominant bacteria with an insignificant occurrence of $0.15 \%$. One fecal coliform organism was isolated from the fiberglass tank and identified as C freurdia $(0.013 \%)$. It is significant to note that the indicator bacterium Escheridia coli was not encountered, thus excluding potential contamination with fecal matter and/or satisfactory disinfection practice.

On the other hand A eromonas spp. (2\%, count wise) one of the fermentative gram-negative bacteria occurred in lower percentage in the household water storage tanks. This might be due to their copiotrophic character that decreases their growth in low nutrient water and the effect of contact time with chlorine in the household tanks along with the competition from other microorganisms that might have affected these groups of bacteria as suggested by LeChevallier \& McFeters (1985b). In Holland, the presence of A eromonas in drinking water is considered to be of potential public health concern, and this genus has been proposed as an indicator of potential risk of bacterial regrowth in the distribution network. The proposed maximum values of A eromonas are $20 \mathrm{CFU} / 100 \mathrm{~mL}$ for firished water and $200 \mathrm{CFU} / 100 \mathrm{~mL}$ for distribution system water (van der Kooij, 1988).

\subsection{Gram-positive bacteria in the PRWST and the influent water}

Thirteen gram-positive bacteria were isolated from the PRWST compared to only 3 isolated from the water inlet and this may be due to that these types of bacteria have been either dwelled in the tanks, in the sediments or biofilm, or were viable but not culturable in the inlet water and then bacterial regrowth has occurred in the tanks.

In this study the gram-positive Bacillus spp. (17.5\%) were the second most dominant genus after Pseudomonas spp. $(42 \%)$ in the tanks. This finding is supported by a study done in Florence, Italy, where Bacillus spp. constituted $57 \%$ of bacteria isolated from the water in the distribution systems (Gambassini $a$ al., 1990). In contrast, it was shown that Gondona terrae a newly isolated bacterium could be found in the inlet water and not in the tanks, 
this may be due to the competition for nutrients in the tanks that favors some bacteria. The dominance of gram-positive bacteria by Bacillus spp. and Artbrobacter spp. especially that these species have been suggested as antagonists to coliforms which interfere with their detection in routine analysis, and thus have public health implications.

\subsection{HPC in the influent water compared with the PRWST}

Drinking water in the cast iron distribution system (water inlet) pouring into the tanks was set as an experimental control data in order to assess any bacterial regrowth in the tanks.

In this study HPC levels increased from $43 \%$ in the water inlet to $57 \%$ in the tanks, due to regrowth of preexisting bacteria. This could be confirmed by the literature; Gibbs (1990) in a study done on some distribution system in UK found that the percentage occurrence of non-fermentative bacteria increased in the water storage tanks from $13 \%$ to $58 \%$. In another study, LeChevallier $e t$ al., 1987 showed that the percentage occurrence of nonfermentative bacteria increased in the water storage tanks, increasing from $14 \%$ in the distribution system to $40 \%$. In addition, this study showed that, $P$. aenuginos a increased from $29 \%$ in the water inlet to $68 \%$ in the tanks. Psendomonads regrowth potential started in the distribution system and continued in the household water storage tanks and reached a maximum when residual chlorine in the tanks reached a lower level in December.

On the other hand, the total coliform bacteria increased from $39 \%$ in the water storage tanks to $57 \%$ in the water distribution system. This increase may be due to the contribution of bacterial regrowth on pipe walls, biofilm, or from other sources of distribution system contamination.

\subsection{Effect of retention time (RT) on the microbial diversity of the fiber glass, PE and cast iron water storage tanks}

This study indicated that bacterial growth has occurred in the fiber glass tank and caused an increase in the bacterial numbers after 5 and 7 days of storage time. It was stated in the literature that variations in the water quality have previously been correlated with the age of water (Momba et al., 2000), water retention (Gibbs et al., 1990; Geldreich, 1996) and stagnation. 
Bacterial growth rate was higher during the first 5 days of storage, where there was 1400 -fold (20 CFU/MI to $28000 \mathrm{CFU} / \mathrm{mL}$ ) mean increase in the bacterial numbers compared to a mean increase of only 1 fold during the period between 5 and 7 days. Most of the microbes in drinking water are heterotrophic and require organic compounds for their carbon and energy sources. The difference in the growth rate at 5 and 7 days of storage could be due to the availability of nutrients. This finding is supported by literature where data showed that during the first period (within 4 days) bacterial numbers increased with an equal proportion decrease in the TOC concentration, but in the second storage period ( 4 to 7 days), the bacterial growth rate decreased beside an increase in the TOC concentration (Sunna-Borgan, 1998).

On the other hand in the PE tanks, within 2 days of storage, more than 9-fold increase of HPC levels occurred (2980 to $27200 \mathrm{CFU} / \mathrm{mL}$ ) after which the plateau phase was reached till day 7 . This finding is in contrast to what is stated in the literature where plateau phase was reached at day 4 and 5 , and this may be due to the availability of high nutrients level in the PE tanks (more carbon sources in the PE structural material) favorable for the HPC growth. This finding is supported by a previous study which showed that the highest average values for total organic carbon (TOO), and bacterial plate count were found in the PE tanks (Sunna-Borgan, 1998).

UV treated water in the cast iron tank showed that at day four a 16-fold increase of HPC ( 1700 to $27700 \mathrm{CFU} / \mathrm{mL}$ ) relative to day 0 could be monitored, after which count was steady till day 7. This finding is supported by a previous study performed in Jordan on household water storage tanks indicated that the log bacterial count increased after the water was stored for 4 and 7 days (Sunna-Borgan, 1998). A 16-fold increase in HPC in the cast iron tank compared to 9 fold increase in the PE tank a difference due to initial values of HPC at day 0 in the $\mathrm{PE}$ tank $(2980 \mathrm{CFU} / \mathrm{mL})$ compared to the cast iron $(1700 \mathrm{CFU} / \mathrm{mL})$. This may be due to the high regrowth pattern in the PE tank.

\subsection{Frequency of occurrence of gram-negative/gram-positive bacteria in the UV treated compared with chlorinated water in some tanks}

In the UV treated drinking water inlet, data showed that the frequency of occurrence of gram-negative bacteria were $54 \%$ in the cast iron tank, $83 \%$ in the PE tank and $75 \%$ in the water inlet. This higher regrowth pattern in the PE tank, especially with gram-negative 
bacteria, could be due to the availability of sediments since they provide nutrients for bacteria to flourish and multiply. This finding is supported by literature where it was shown in a previous study on the same water storage tanks that sediments were present in higher concentration in the PE tanks than in the cast iron tanks, and colony counts in the sediments ranged from $5 \times 10^{3}$ up to $7 \times 10^{5}$ CFU/mI (Moubayed, 2002). Similarly Sunna-Borgan in 1998 showed that the cast iron tanks had lower density of sediments, $4 \times 10^{-3} \mathrm{~kg} / \mathrm{m}^{3}$ compared to $9 \times 10^{-3} \mathrm{~kg} / \mathrm{m}^{3}$ in the PE water storage tanks.

On the other hand, in the chlorinated drinking water inlet in the city, data showed that the frequencies of occurrence of gram-negative bacteria were $86 \%$ in the cast iron tanks, $50 \%$ in the PE tank, and $87 \%$ in the distribution system. In contrast to what is stated previously this low frequency of gram-negative bacteria in the PE water storage tank may be the consequence of their recently installments on the roof top of the building (<1 month), thus low levels of sediments in such PE tank. Additionally this high occurrence of gram-negative bacteria in the water of distribution system may be due to biofilm regrowth due to intermittent water supply and inefficient chlorination.

\subsection{Influent water quality}

It was shown in this study that opportunistic pathogens such as $P$. aeruginosa (2 of 7 samples), E. sakazakü (2 of 7), E. agglomerans ( 1 of 7 ) and A erommas sobria ( 1 of 7), in addition to the dominant bacterium Burkbolderia catacia (5 of 7) were detected in the drinking water samples collected from Byblos city. The presence of such opportunistic pathogens could be attributed to inefficient chlorination. Thus the city drinking water is not of acceptable microbiological condition after reaching consumers due to the considerable occurrence of such microorganisms. However, $P$. aemginasa and coliforms were not detected in the UV treated drinking water samples.

\subsection{Chlorination effect on HPC diversity \& levels in the PE water storage tanks}

In the first run it was established that a concentration of $4 \mathrm{mg} / \mathrm{L}$ with a residual chlorinewater contact time of more than 20 hrs was sufficient to kill or injure all culturable bacteria in the tank. This finding is supported by literature where in vitro studies of inactivation of 
human pathogenic bacteria transmitted by potable water reported that 0.1 to $1.0 \mathrm{mg} / \mathrm{L}$ free chlorine inactivated ( $99 \%$ kill) most pathogenic vegetative bacteria within only $60 \mathrm{~min}$ (Sobsey, 1989). Furthermore it is reported that coliforms mainly Klebsidla spp. and Enterdbater spp. were detected in distribution systems even in the presence of 3-4 mg/L of chlorine (Martin et al., 1982). This may also support that the inlet UV treated water was free of coliform bacteria and in agreement to what is previously discussed.

On the other hand, a second run showed that a free chlorine concentration of $0.11 \mathrm{mg} / \mathrm{L}$ inactivated $(99.6 \%$ kill) all HPC bacteria within less than one day $(20 \mathrm{~h})$ with the exception of the gram-positive rod Commobaterium zariabilis (Caseobater pobmorphis). This finding is supported by literature where it was hypothesized that the thicker cell wall of gram-positive bacteria aided in their survival and predominance in the chlorinated water (LeChevallier $a t$ al., 1980). Furthermore it was shown here that keeping a free residual chlorine $\geq 0.25 \mathrm{mg} / \mathrm{L}$ was enough to keep levels of culturable HPC undetected ( $100 \%$ kill).

\subsubsection{Reverse mechanism of chlorination}

In this experiment it was demonstrated that when free residual chlorine fell down below $0.10 \mathrm{mg} / \mathrm{L}$, after chlorine tablets has been removed from the water storage tank, bacterial regrowth would reoccur and this implies that bacteria may be injured rather than killed. This may also suggest that sediment bacteria and/or biofilm formation bacteria and/or bacteria injured by chlorine could have recovered and re-supplied the water with high HPC This finding is supported by literature which showed that biofilm attach more on the $\mathrm{PE}$ tank than on the cast iron tank, as well the presence of high sediments dry weight which supply water with nutrients for bacterial regrowth (Moubayed, 2002). In addition of importance Commebacterium zariabilis survived chlorine concentration of $0.17 \mathrm{mg} / \mathrm{L}$ even after 1 day $(24$ h) of water-chlorine contact time.

\subsection{Chlorination effect on HPC diversity \& levels in the cast iron tank}

In contrast to the PE tank, some bacteria survived residval chlorine of $0.26 \& 0.19 \mathrm{mg} / \mathrm{L}$. Five bacterial strains survived chlorination, and only one isolate (20\%) which belonged to the gram-negative (slightly gram-positive) curved shape rods endured free residual chlorine of $0.26 \mathrm{mg} / \mathrm{L}$. This isolate could not be identified but suspected to be one of the fast 
growing nontuberculous mycobacteria (NTM). It was stated in literature that these types of bacteria survive higher chlorination levels in water ranging from $0.3 \mathrm{mg} / \mathrm{L}$ to $0.7 \mathrm{mg} / \mathrm{L}$ (Carson et al., 1978). The other 4 bacteria (80\%) were part of various gram-positive endospore forming Bacilli. This finding is supported by literature where gram-positive bacteria survived free chlorination better than gram-negative HPC bacteria and predominate in chiorinated treated water (LeChevallier, 1980). In addition another study held in Florence, Italy showed the dominance of gram-positive bacteria in the water distribution systems (Gambassini et al., 1990).

This high occurrence of gram-positive bacteria is suggested to be due to the presence of the peptidoglycan layer as well as the presence of Bacilli which are possible endospore formers which makes this group more resistant to chlorine than the gram-negative bacteria which have an outer membrane that oxidizes by the action of chlorine. Staphlococus saproplyticus was isolated at high chlorine levels of $0.19 \mathrm{mg} / \mathrm{L}$ and this bacterium habitat is the nomal flora of human skin and mucosa of genitourinary tract, and its presence in water, as a transient bacterium, could be due to contamination of handling water samples (Kloos \& Bannerman, 1994). Furthermore, Gondona nibropertinatus survived lower chlorination levels of 0.09 and $0.06 \mathrm{mg} / \mathrm{L}$. Gordona spp. are partially acid-fast aerobic Actinomycetes which are considered opportunistic pathogens (Beaman et al., 1995).

On the other hand, during this study data showed that keeping a free residual chlorine $\geq 0.35 \mathrm{mg} / \mathrm{L}$ was enough to maintain culturable HPC levels undetected. This finding was supported by literature, where Greetham (1996) recommended keeping a residual chlorine concentration $\geq 0.4 \mathrm{mg} / \mathrm{L}$ in the storage tanks.

\subsection{Microbial identification systems: Biolog vs. API}

Results indicate that, for the cases involving the environmental strains, the API-2ONE and the Biolog GN identification results are generally not in good agreement, as derived from both the $24 \mathrm{~h}$ and $48 \mathrm{~h}$ incubation readings. The Biolog system assigned identities to 52 $(91.2 \%)$ gram-negative organisms tested and the API identified $47(82.5 \%)$. This finding is supported by literature where it was stated that the Biolog GN system offers finer resolution due to its utilization of a higher number of carbon substrates, thus it is better 
suited for studies involving assessment of microbial diversity (Truu et al., 1999). The percentage of isolates that were assigned the same identity (genus \& species) by both systems was $24.6 \%$ (14 of 57 ). Moreover $33.3 \%$ were not similar at the genus level, while $15.8 \%$ were not similar at the species level. In contrast to what is stated in the literature where the identification results of environmental strains using the Biolog GN and the API- 20NE were generally in good agreement at the genus level, while comparison of identification results utilizing the assigned species names did not show high consensus in the identification results (Truu et al., 1999). The differences observed between the Biolog and the API at the species and genus level could be also partly attributed to the absence of some of the tested strains from the API database. Consequently, as to species level isolates such as $P$. symantha, $P$. atronellolis, Vibrio barreyi, Vibrio tubiasbii, Pastemella trebalosi, Acinetobater genospecies 11, Flarobacterium jobrsomiae and Flawbacterim fermugineum were identified by the Biolog system but do not exist in the API database. Furthermore, both genera Bumkbodderia and Aquaspirillum were identified by the Biolog but not present in the API database.

On the other hand identification of 31 isolates belonging to Pseudomonas however, revealed better agreement in the results at both the genus and species level. The percentage of isolates that were assigned the same identity by both systems was $45.2 \%$. Differences were seen between both systems, where $9.68 \%$ and $35.5 \%$ of the isolates using the API were assigned to different species or genera, respectively. According to Holmes et al. (1994), the Biolog system performed best with oxidase-positive fermenters and biochemically active non-fermenters and had the most problems with unreactive non-fermenters. Leclerc and Guillot (1992) showed that approximately $80 \%$ of strains isolated from natural waters were not identifiable at the species level and that the majority of strains which could be identified were fluorescent members of the genus Pseudomonas. 
5.12 Hygienic aspect of the bacterial population in the household water storage tanks and the influent water

Drinking water is not intended to be sterte, and few heterotrophic bacteria pose a public heath risk. Yet the occurrence and growth of bacteria that are considered pathogenic or opportunistic pathogens should not be over looked. The presence of such microorganisms in drinking water will cause a public health threat especially for the immunocompromised patients. Opportunistic pathogens like $P$. aeruginosa (26.2\%) and Bumkbolderia cepacia (18.9\%) as well as some coliform organisms like Enterobater sakazakii and Citrobacter fremadit, in addition to A eromonas spp. were discussed in detail previously in the literature review.

\subsubsection{Minor occurrences of other gram-negative non enteric bacteria}

Omreomonas liteda ( $P$. luteda) with an occurrence of $0.013 \%$ in the water storage tanks is an opportunistic organism that is distributed in the environment, including moist hospital environments, and it is not part of the normal human flora (Rahav et al., 1995).

A cintobater spp. were also detected in the household water storage tanks and their occurrences were insignificant $(0.03 \%)$. They are opportunistic pathogens which were found to be difficult to treat, due to their frequent multiple antibiotic resistance to major antibiotics available for treatment of nosocomial infections (Bergogne-Berezin, 1994). In addition they have been isolated from distribution system water, and found to be sensitive to chlorine concentrations $>2 \mathrm{mg} / \mathrm{L}$. Their dominance was found to be related to association with carbon fines, turbidity particles, and other biofilm bacteria such as Legionella pretmophila (Geldreich, 1996).

Alcaligenes xyloscocidars occurred in the PRWST and inlet water at $0.84 \%$ and $0.98 \%$ respectively. Alcaligenes xyloscxidans has been implicated in outbreaks of nosocomial infections, and could be a transient colonizer of human gastrointestinal or respiratory tract of patients with cystic fibrosis (Dunne \& Maisch, 1995).

Flawbacterizm spp. were isolated from the PRWST but their occurrences were insignificant $(<1 \%)$. However, Empedobater breis (Flau breze, 4\%) and Omsecbacterium meningosepticum (Flaw meningosepticum 4\%) isolated from the city drinking water are considered to be opportunistic pathogens and have been linked to infection in infants and immunosuppressed people (Herman, 1978). 


\subsection{Conclusions \& Recommendations}

This study revealed that potable water in Byblos city is not of acceptable microbiological conditions after reaching consumers due to the considerable occurrences of some opportunistic pathogens and coliforms. Inefficient chlorination was one of the major reasons for this regrowth in the water of the distribution systems.

Microbial regrowth occurred in the household water storage tanks and caused substantial deterioration in the quality of drinking water influent. Water storage was found to have the greatest impact on this microbial regrowth pattern. On the other hand and according to the microbilogial techniques used it was demonstrated that more microbial diversity could be detected in the filtration technique relative to the spreading technique, while the mean $\mathrm{HPC} / \mathrm{mL}$ levels where higher by 1.85 to 2.45 times in the spreading technique than the filtration technique.

The enumeration and identification of bacteria showed that some of the microorganisms involved in this regrowth were, opportunistic pathogens, coliforms and other endogenous normal resident heterotrophs which were considered as coliformantagonistic bacteria. Thus this microbial regrowth imposes public health hazard in household usage or if used for drinking purposes. Therefore, preventive measures are urgently needed to minimize this imposed hazard under the prevalent water intermittent supply in Lebanon.

This can be accomplished by:

- Speciation of the HPC to determine the presence or absence of opportunistic pathogens and thus to utilize suitable treatment strategies is crucial for proper management.

- More sudies should be conducted towards the development of a better design of household water storage tanks, in order to get rid of sediments by implementing bottom fountains for washing, and to reduce biofilm formation.

- The adoption of a continuous flow regime in supplying the water to consumers is recommended. If this is not possible due to water shortage, usage of point-of-use water treatment devices or addition of chlorine disinfectant to tanks is recommended. 
- Post-storage chlorination using chlorine tablets showed effective treatment against HPC and other bacteria. Accordingly, preventive measures to minimize bacterial growth in water reservoirs were suggested and included the maintenance of chlonine residual above $0.35 \mathrm{mg} / \mathrm{L}$ and an increase in the water turnover with a routine tank inspection, maintenance and sediment cleaning.

- The use of stainless steel tanks could be used as an optional material for water storage since they are not transparent, smooth for cleaning purposes and do not corrode.

- More elaborated work should be done on comparing spreading vs. filtration microbiological techniques in order to establish the best method to determine the HPC level and microbial variety in water.

- More studies should be conducted concerning the effect of Baillus, Arthrobacter, and Staphlococas on routine coliform analysis.

- The usage of protozoa as coliform grazer to control the spread of coliform in water should be tested.

- Identification of slow growing environmental isolates cannot be done using any of the available commercial kits, like the Biolog and API systems. It is suggested that the possible way would be through the use of molecular techriques. 


\section{BIBLIOGRAPHY}

Abu Kwaik, Y., Gao, L., Stone, B., Venkataraman, C. \& Harb, O. (1998). Invasion of protozoa by Legiondla pretmophila and its role in bacterial ecology and pathogenesis. Applied Enirommental Mimobiology, 64, 3127-3133.

Allen, M., Taylor R \& Geldreich E. (1980). The occurrence of microorganisms in water main incrustations. A merican Water Wotes A ssociation, 72, 614- 625.

Amblard, C, Bourdier, G., Carrias, J., Maurin, N. \& Quiblier, C (1996). Evolution saisonniere de la structure des communautes microbiennes dans un reservoir d'eau potable. Water Resames, 30, 613-624.

APHA et al. (1998). Standard methods for the examination of water and wastewater (20th ed., L. Clesceri, A. Greenbergand A. Eaton, Eds.). Washington: APHA.

Atlas, R. (1999). Legionella: From environmental habitats to disease pathology, detection and control. Emiromment Microbidogy, 1, 283-293.

Baker, H., Hegarty, P., Redmond, B., Reed, A., \& Herson, S. (2002). Effect of oxidizing disinfectants (chlorine, monochloramine, \& ozone) on Helicobacter plori. Applized Enironmental Microbiology, 68, 981-984.

Baribeau, H. Prévost, M, Desjardins, R. \& LaFrance, P. (2001). Changes in chlorine and DOX concentrations in distribution systems. A merican Water Works A ssociation, 93,102-114.

Beaman, B., Saubolle, M. \& Wallace, R (1995). Nocardia, Rhodococcus, Streptomyces, Oerskovia, and other aerobic Actinomycetes of medical importance. [n.p]. In Murray, P.

Baron, E., Pfaller, M. et al., editors. Manual of clinical microbiology, ( $6^{\text {th }}$ ed.).Washington: American Society for Microbiology.

Benenson, A., editor. (1995). Control of communicable diseases manual, (16 th ed). Washington: APHA.

Bergogne-Berezin. (1994). Acinetdader spp. saprophytic organisms of increasing pathogenic importance. ZbL. Bakteridogie, 281,389-405.

Block, J., Servais, P. \& Werner, P. (1993). In Proceedings of Technology Conference on Bacterial Regrowth-Bugs, Molecules and Surfaces, p. 3-35.

Bull, R, Gerba, C. \& Trussell, R. (1990). Evaluation of the health risks associated with disinfection. Critical Reciezes Enimonmental Control, 20,77-114. 
Cahill, M. (1990). Virulence factors in motile Aeromonas species. Jamal of Applied Bacteridogy, 69, 1-16.

Camper, A. (1995). Factors influencing biofilm growth in drinking water distribution systems. PhD Thesis. Montana State University-Bozeman.

Carson, L., Petersen, J., Favero, S. \& Aguero, M. (1978). Growth characteristics of atypical mycobacteria in water and their comparative resistance to disinfectants. Applied Enirommental Microbidogy, 36, 839-846.

Carter, J., Rice, E., Buchberger, S. \& Lee, Y. (2000). Relationships between levels of heterotrophic bacteria and water quality parameters in a drinking water distribution system. Water Researd, 34, 1495-1502.

Chitton, P., Lawrence, A \& Stuart, M. (1995). The impact of tropical agriculture on groundwater quality. In Gromkeater quality (Nash, H. and McCall, G. Eds., pp.113-123).

London: Chapman and Hall.

Clark, J., Burger, C. \& Sabatinos, L. (1982). Characterization of indicator bacteria in municipal raw water, drinking water and new main water samples. Canadian Joamal of Micrabidogys 28, 1002-1013.

Coia, J. (1998). Cinical, microbiological and epidemiological aspects of Esdheridria odi O157 infection. FEMS Imon Med Microbidogy, 20, 1-9.

Collins, C., Grange, J. \& Yates, M. (1984). Mycobacteria in water. Joumal of Applized Bacteriology, 57, 193-211.

Costerton, J., Lewandowski, Z. Caldwell, D., Korber, D. \& Lappin-Scott, H. (1995). Microbial biofilms. A mual Rezieres of Microbidogy, 49, 711-745.

Covert, T., Rodgers, M., Reyes, A. \& Stelma, G. (1999). Occurrence of nontuberculous mycobacteria in environmental samples. A pplized Emiromental Mionobidiogy 65, 2492-2496.

Dabboussi, F., Hamze, M., Elomari, M., Verhille, S., Baida, N., Izard, D. et al. (1999). Pseudomonas libanensis sp. Nov., a new species isolated from Lebanese spring waters. Intemational Jomal of Systematic Bacteridogy, 49, 1091-1101.

Daniel, P., Meyerhofer, P., Zafer, M. \& Rice. E. (1993). Assimilable organic carbon formation and control, In Ozone in water and reastecuater treatment (vol. 2, p. S18:1-14). Stamford, Conn.: Pan American Group.

Day, G., Hart, T., McKelvie, D. \& Beckett, R (1997). Influence of natural organic matter on the adsorption of biocides onto goethite. I. Gamma-BHC and atrazine. Emironmental Tedmologs, 18, 769-779. 
Dodds, L., King, W., Woolcott, C. \& Pole, J. (1999). Trihalomethanes in public water supplies and adverse birth outcomes. Epideriology, 10, 233-237.

Donlan, R \& Costerton, J. (2002). Biofilms: survival mechanisms of clinically relevant microorganisms. Ainical Microbidogy Reietes, 15, 167-193.

Drasar, B. \& Hill, M. (1974). Human intestinal flora. London: Academic Press.

Dunne, W. \& Maisch, S. (1995). Epidemiological investigation of infections due to Alcaligenes species in children and patients with cystic fibrosis: use of repetitive-elementsequence polymerase chain reaction. Cimical Infectious Diseases, 20, 836.

Dychdala, G. (1991). Chlorine and chlorine compounds, p. 131-151. In S. Block (Ed), Disinfection sterilization and preserzation (4th $e d$.). Philadelphia: Lea \& Febiger.

Ellgas W. \& lee R. (1980). Reservoir coating support bacterial growth. A. W.W. A, 72, 693695.

Ellis, K. (1991). Water disinfection; a review with some consideration of the requirements of the third world. Critical Revieres Emironertal Contrd, 20, 341-407.

Engelbrecht, J. (1993). An assessment of health aspect of the impact of domestic and industrial waste disposal activities on groundwater sources-A literature review. A report to the Water Reseand Commission by the gramdiater programme division of zeater Tedmology CS.I.RStellenbosh:WRCProject no 371/1/93.

Environmental Protection Agency (EPA). (1999). Drinking Water and health what you need to know? Washington: [n.p.]. Retrieved January, 18, 2003 from http://www.epa.gov.

Environmental Protection Agency (EPA). (1986). Drinking Water and health. Washington: [n.p.]. Retrieved February, 10, 2003 from http://www.epa.gov.

Escobar, C \& Randall, A. (2001). Assimilable organic carbon (AOO) and biodegradable dissolved organic carbon (BDOC): Complementary measurements. Water Resames, 35, 4444-4454.

Falkinham, J. (1996). Epidemiology of infection by nontuberculous mycobacteria. Cintcal Micobiology Retieus, 9, 177-215.

Falkinham, J., Norton, C. \& LeChevallier, M. (2001). Factors influencing numbers of Myodacterium atum, Mycabacterium intracellulare, and other mycobacteria in drinking water distribution systems. A pplied Enurommental Microbidiogy, 67, 1225-1231.

Fass, S., Dincher, M, Reasoner, D., Gatel, D. \& Block, J. (1996). Fate of Eschendhia coli experimentally injected in a drinking water distribution pifot system. Water Resources, 30 , 2215-2221. 
Fields, B. (1996). The molecular ecology of Legionellae. Trends Microbiology, 4, 286-290.

Ford, T. \& Colwell, R (1996). A global dedine in microbiological safety of reater: A call for action Washington, DC: American Academy of Microbiolgy.

Foster, S. (1995). Groundwater for development- An overview of quality constraints. In Groumdteuter Quality (Nash, H and McCall, G. J. Eds., pp.1-3). London: Chapman \& Hall.

Fransolet G., Villers G. \& Masschelein W. (1985). Influence of temperature on bacterial development in waters. Ozone Science and Engineering 3, 205-227.

Gambassini, L., Sacco, C., Lanciotti, E., Burrini, D. \& Griffini, O. (1990). Microbial quality of the water in the distribution system of Florence. Joumal of Water Supply Reseands and Tedonology-A qua, 39, 258-264.

Gatel, D., Servais, P., Block, C., Bonne, P. \&. Cavard, J. (2000). Microbiological water quality management in the Paris suburbs distribution system. Jomal Water SRT - A qua, $49,231-241$.

Gauthier, C., Prevost, M. Mailly, J. \& Rompre, A. (1996). Impact de la teneur en acides amines sur la stabilite microbiologique de l'eau potable: essais en reacteurs annulaires. [n.p.]: [n.p.].

Gauthier, V., Redercher, S. \& Block J. (1999). Chlorine inactivation of Sphingomonas cells attached to goethite particles in drinking water. A pplied Enimormental Micobiology, 65, 355357.

Geldreich, E. (1996). Creating microbial quality in drinking water. In Microbial quality of vater supply in distribution systems (E. Geldreich, Ed., pp. 78-79). New York: Lewis Publishers.

Geldreich, E., Fox, K., Goodrich, J., Rice, E., Clark, R \& Swerdlow, D. (1992). Searching for water supply connection in the Cabool, Missouri disease outbreak of Eschenidria coli O157:HD. Water Researd, 26, 1127-1137.

Gibbs, R, Sutt, J. \& Croll, B. (1990). Microbiological and trihalomethane response to booster chlorination. Joumal of the Institute of Water E Enirommental Management, 64, 596-602.

Gilligan, P. (1991). Microbiology of airway disease in patients with cystic fibrosis. Cinical Microbiology Retieues, 4, 35

Gonzalez, C., Pettit, E., Valadez, V. \& Provin, E. (1997). Mobilization, cloning and sequence determination of a plasmid encoded polygalacturonase from a phytopathogenic Bumbbolderia (Pseudomonas) cepacia. Mdecular Plant-Microbe Interaction, 10, 840-851.

Gorden, W., Hazen, C. \& Fliermans, B. (1993). Rapid screening for bacteria capable of degrading toxic organic compounds. Jotmal of Microbiological Methods, 18, 339-347. 
Govan, J. R \& Deretic, V. (1996). Microbial pathogenesis in cystic fibrosis: mucoid Pseudomonas aentugionosa and Bumbbolderia cepacia. Microbidogy Revieut, 60, 539-574.

Greetham, M. (1996). The effect of water treatment on the corrosion and biofilm growth promoting properties of water within distribution systems. $\mathrm{PhD}$ Thesis. London University.

Hach Company. 2000. The Use of Indicator Organisms to Assess Public Water Safety. Technical Information Series-Booklet No. 13. 2000. U.S.A.

Hardalo, C. \& Edberg, S. (1997). Pseudomonas aenuginasa: assessment of risk from drinking water. Critical Recieves Microbiology, 23, 47-75.

Herman L. (1978). The slow-growing pigmented water bacteria problems and sources. $A d v$ Appl Micnabiology, 23, 155-171.

Hashwa, F., 8 Tokajian, S. (2000). Change of water quality in the distribution system of a residential area in Beirut. IV International Conference: Water Supply and Water Quality, Krakow, Poland.

Hoffman, P., Death, J. \& Coates, D. (1981). The stability of sodium hypochlorite solutions. In Collins, H, Allwood, C., Bloomfield, F., and Fox, A. (Eds. pp. 77-83.), Disinfectants: Their use and ezaluation of effectiveness. London: Academic Press.

HMSO. (1994). The microbiological examination of water. Reports on public health and medical subjects memorandum No. 71. Department of health and social security, London.

Holmes, B., Costas, M., Ganner, M., On, S. \& Stevens, M. (1994). Evaluation of Biolog system for identification of some gram-negative bacteria of clinical importance. Jormal of Cinical Microbidogy, 32, 1970-1975.

Huck P., Fedorak P. \& Anderson W. (1992) Biodegradation of aquatic organic matter with reference to drinking water treatment. Sa. Total Eninon, 117/118, 531-541.

Hureiki, L. (1993). Etude de la chioration et de l'ozonation d'acides amines libres et combines en milieu aqueux dilue. $\mathrm{PhD}$ Thesis. University of Poitiers, Poitiers, France.

Jackson, S., Goodbrand, R, Johnson, R., Odorico, V., Alves, D., Rahn, K. et al. (1998). Esdxeridia coli O157:H7 diarrhoea associated with well water and infected cattle on an Ontario farm. Epidemid. Infext., 120, 17-20.

Janda, J. (1991). Recent advances in the study of the taxonomy, pathogenicity, and infectious syndromes associated with the genus Aeromonas. Cinical Microbidogy Reziezes, 4, 397-410. 
Janda, J., \& Abbott, S. (1998). Evolving concepts regarding the genus Aeromonas: an expanding panorama of species, disease presentations, and unanswered questions. Cinical Infections Diseases, 27, 332-344.

Janda, J., Abbott, S., Khashe, S., Kellogg, G. \& Shimada, G. (1996). Further studies on biochemical characteristics and serologic properties of the genus Aeromonas. Jamal of Cinical Microbidogy, 34, 1930-1933.

Jones, D. (1999). Potential health risks associated with the persistence of Esdheridria coli O157:H7 in agricultural environments. Soil Use Manage, 15, 76-83.

Katz, S. \& Hammel, J. (1987).The effect of drying, heat, and $\mathrm{pH}$ on the survival of Legiondla preumophila. A m. Ain Lab. Sa., 17, 150-156.

King, W. \& Marrett, L. (1996). Case-control study of bladder cancer and chlorination byproducts in treated water (Ontario, Canada). Canker Causes Contrd, 7, 596-604.

Kloos, W. \& Bannerman, T. (1994). Update on clinical significance of coagulase-negative staphyiococci. Ainical Microbidogy Recieves, 7, 117.

Korshin, G., Benjamin, M \& Sletten, R (1997). Adsorption of natural organic matter (NOM) on iron oxide: effects of NOM composition and formation of organohalide compounds during chlorination. Water Resomes, 31, 1643-1650.

Krieg, N., ed. (1984). Bergey's Manual of Systematic Bacteriology (Vol. 1). Baitimore, Md: Williarns and Wilkins.

LeChevallier, M., Seidler, R, \& Evans, T. (1980). Enumeration and characterization of standard plate count bacteria in chlorinated and raw water supplies. Appl. Enirom Microbidogy, 40, 922-930.

LeChevallier, M. \& McFeters, G. (1985b). Enumerating injured coliforms in drinking water. J. Am Water Wonks Association, 77, 81-87.

LeChevallier, M, Babcock, T. \& Lee. R (1987). Examination and characterization of distribution system biofilms. Applied E mirommental Microbidogy, 53, 2714-2724.

LeChevallier, M (1990). Coliform bacteria in drinking water: a review. $A$ WWA, 82, 74-86.

LeChevallier, M., Schultz, W. \& Lee, R. (1991) Bacterial nutrients in drinking water. Applied Enironmental Micobiology, 57, 857-862.

LeChevallier, M., Lowry, C., Lee, R \& Gibbon, D. (1993). Examining the relationship between iron corrosion and the disinfection of biofilm bacteria. AWWA, 85, 111-123. 
LeChevallier, M. Welch N. \& Smith D. (1996). Full-scale studies of factors related to coliform regrowth in drinking water. Applied Enimomental Microbidogy, 62, 2201-2211.

Leclerc, H. \& Guillot, E. (1992). Etude de la flore bactérienne de deux sources d'eaux minérals naturelles; caractérisation par les profiles de restriction des gènes codants pour les ARN ribosomaux; spécificité et stabilité biologique. Bull. Acad. Natl. Med., 176, 1491-1504.

Leclerc, H. Moreau, A. (2002). Microbiological safety of natural mineral water. FEMS Micobidogy Reciezes, 747, 1-16.

LeDantec, C, Duguet, J-P., Montiel, A. Dumoutier, N. Dubrou, S. \& Vincent, V. (2002). Occurrence of Mycobacteria in water treatment lines and in water distribution systems. Applied Enimormental Microbidogy, 68, 5318-5325.

Lehtola, M., Miettinen, I., Vartiainen, T., Rantakokko, P., Hirvonen, A. \& Martikainen, P. (2003). Impact of UV disinfection on microbially available phosphons, organic carbon, and microbial growth in drinking water. Water Researd, 37, 1064-1070.

Lippy, E. (1986). Chlorination to prevent and control waterborne diseases. $A W W A ., 78$, 49-52.

Lippy, E. \& Waltrip, S. (1984). Waterborne disease outbreaks 1946-1980: A thirty five-year perspective. J. Am Water Works Association, 76, 60-67.

LiPuma, J. \& Mahenthiralingam, E. (1999). Commercial use of Bukbolderia cepacia: are there additional threats? Emergency Infextious Diseases, 5, 5-6.

Lisle, J., Broadaway, S., Prescott, A., Pyle, B., Fricker, C. \& McFeters, G. (1998). Effects of starvation on physiological activity and chlorine disinfection resistance in Esdheridhia coli O157:H7. A pplied Enirommental Microbiology, 64, 4658-4662.

Madsen, E. \& Ghiorse, W. (1993). Groundwater microbiology: subsurface ecosystem processes. In: A quatic Micndidogy. An Ecological A pproads (Ford, T.E., Ed., pp. 167-213). Boston, MA: Blackwell Scientific Publications.

Mahenthiralingam, E., Bischof, J., Byrne, K., Radomski, C., Davies, E., \& Yossef, A. et al. (2000). DNA-Based diagnostic approaches for identification of Bukholderia apacia complex, Bumkbolderia riemamiensis, Bumkbolderia multiwomans, Bukbholderia stabilis, and Bukboldenia copacia Genomovars I and III. Joumal of Cinical Microbiology, 38, 3165-3173.

Maier, R \& Pepper, I. (2000). Terrestrial environments. In: Emiromental Microbiology (Gerba, C., Maier, R. \& Pepper, I. Eds., pp. 61-89). London: Academic Press.

Martin S., Gates H., Tobbin S., Sumarah R. \& Forestall P. (1982). Factors affecting coliform bacterial growth in distribution systems. $A W W A, 74,34-37$. 
Matin, A. (1992). Physiology, molecular biology and applications of the bacterial starvation response. J. Appl Bacterid, Symp. Suppl., 73, 49-57.

McCann, P., Kidwell, J. \& Matin, A. (1992). Microbial starvation survival, genetics. In: Encydopedia of Microbidogy (Vol., 3, pp.159-177). London: Academic Press.

McDade, J., Shepard, C, Fraser, D., Tsai, T., Redus, M. \& Dowdle, W. (1977). Legionnaires' disease: Isolation of a bacterium and demonstration of its role in other respiratory disease. National English Jommal of Medicine, 297, 1197-1203.

McGeehin, M., Reif, J., Becher, J. \& Mangione, E. (1993). Case-control study of bladder cancer and water disinfection methods in Colorado. A merican Jamal of Epidenidogy, 138, 492-501.

McFeters, G., Kippin J. \& LeChevallier, M. (1986). Injured coliforms in drinking water. A pplied Eniromental Microbiology, 51, 1-5.

Miettinen, T., Vartiainen, T. \& Martikainen, J. (1997). Phosphorus and bacterial growth in drinking water. A ppliod Emirommental Microbidogy, 63, 3242-3245.

Miller, J., \& Rhoden, L. (1991). Preliminary evaluation of Biolog, a carbon source utilization method for bacterial identification. Jamal of Cinical Microbidogy, 29, 1143-1147.

Millership, S. \& Chattopadhyay, B. (1985). Aeromonas byatrophila in chlorinated water supplies. J. Hosp.Infext., 6, 75-80.

Mintz, E., Reiff, E. \& Taux, R (1995). Safe water treatment and storage in the home. $J A M A, 273,848-953$.

Momba, M. Cloete, T., Venter, S. \& Kfir, R. (2000). Influence of disinfection processes on the microbial quality of potable groundwater in a laboratory-scale system model. Jamal of Water Supply Researdb and Tedmdogy-AQUA, 49, 23-34.

Morita, R (1997). Bacteria in oligotrophic environments. Starvation-survival lifestyle. New York: Chapman and Hall.

Moubayed, N. (2002). Deterioration of drinking water quality in UV treated household water storage tanks. Masters Thesis. Lebanese American University, Lebanon.

Myo Han, A. New, K., Midorikawa, Y. \& Shwe, S. (1987). Household faecal contamination and diarrhoea risk. Trop. Goog Medicine, 41, 138-140.

Najm, I. \& Trussell, R. (2001). NDMA formation in water and wastewater. J. AmWater. Wokks Assciation, 93, 92-99. 
Nataro, P. \& Kaper, J. (1998). Diarheagenic Eschenidia coli. Cinical Microbiology Retieres, 11, 142-201.

Nemedi, L. \& Lanly, B. (1971). Incidence and hygienic importance of Pseudomonas aeruginosa in water. A cta microbiologica A cademiae Scientianium Humgaricae, 18, 319-326.

Oliver, J. (1993). Formation of viable but nonculturable cells. In: Staration in bacteria (Kjelleberg, S., Ed., pp. 239-272). New York: Plenum Press.

Parrotta, M. \& Bekdash, F. (1998). UV-disinfection of small groundwater supplies. AWWA., 90,71-81.

Payment, P. Richardson, L. Siemiatycki, J. Dewar, R. Edwardes, M. \& Franco, E. (1991). A randomized trial to evaluate the risk of gastrointestinal disease due to consumption of drinking water meeting current microbiological standards. Am J. Public Health, 81, 703.

Plassard, S. (1992). "Rain Maps of Lebanon". Retrieved December 12, 2002, from http://csrd.lau.edu.lb/Publications/StudentReports/.

Pontius, F. (1995). An update of the federal drinking water regulations. $A W W A, 87,48$.

Pontius, F. (1999). Complying with future water regulations. $A$ WWA, 91, 46-58.

Rahav, G., Simhon, A. \& Mattan, Y. et al. (1995). Infections with Omseomonas luteda and Flaumonas onzibabitans. Medicine, 74, 83

Reasoner, D., Blannon J., Geldreich E. \& Barnick J. (1989). Nonphotosynthetic pigmented bacteria in potable water treatment and distribution system. Applied Eminomental Micobidogy, 55, 912-921.

Reasoner, D. \& Geldreich, E. (1979). A new medium for the enumeration and subculture of bacteria from potable water. In: A bstract of the A mual Meting of the A merican Society for Microbidogy, p. 180. Washington, DC. American Society for Microbiology.

Reasoner, D. \& Geldreich, E. (1985). A new medium for the enumeration and subculture of bacteria from potable water. Applied Enimonmental Microbiology, 49, 1-7.

Reiff, F. (1996). "Biofilm in Water Distribution Systern," Drinking Water \& Health --A Publication of the Public Health Advisory Board to the Chlorine Chemistry Council ${ }^{*}$ [n.p.].

Reitler, R. \& Seligman, R. (1957). Pseudomonas aengizasa in drinking water. Jamal of A pplizd Bacteridogy, 20, 145-150.

Rompréa, A., Servais, P., Baudarta, J., de-Roubinc, M. \& Laurenta, P. (2002). Detection and enumeration of coliforms in drinking water: current methods and emerging approaches. Jamal of Microbiological Methods, 49, 31-54. 
Rook, J. (1974). Formation of haloforms during chlorination of natural waters. Water Treatment Examination, 23, 234-243.

Roszak, B. \& Colwell, R (1987). Survival strategies of bacteria in the natural environment. Micobiology Retieus, 51, 365-379.

Rudd, T., Sterritt, R \& Lester, J. (1982). The use of extraction methods for the quantification of extracellular polymer production by Klebsiella aerogenes under varying cultural conditions. Eumopean Jaumal of A ppied Microbidogy Bictedmology, 16, 23-27.

Russell, A (1990). Bacterial spores and chemical sporicidal agents. Cinical Microbidogy Recieves, 3, 99-119.

Rutala, W. \& APIC Guideline Committee. (1996). APIC Guideline for selection and use of disinfectants. Am J. Infect. Contrd, 24, 313-342.

Rutala, W. \& Weber D. (1995). Use of chemical germicides in the United States: 1994 and beyond, pp. 1-22. In W. A Rutala (Ed.), Cherncal gemicides in bealth care Washington DC: Association for Professionals in Infection Control and Epidemiology.

Rutala, W. \& Weber D. (1997). Uses of inorganic hypochlorite (Bleach) in health-care facilities. Cinical Mimobidogy Reziezes, 10,597-610.

Sanden, G., Fields, B., Barbaree, J. \& Feeley, J. (1989). Viability of Legionella pnampphila in chlorine-free waters at elevated temperatures. Comert Microbidogy, 18, 61-65.

Schardinger, A (1967). In Mossel, D. Ecological principles and methodological aspects of the examination of foods and feeds for indicator microorganisms. J. Assoc. Off. Anal. Ohemistry, 50, 91-104.

Schoenen, D. (2002). Role of disinfection in suppressing the spread of pathogens with drinking water: possibilities and limitations. Water Researd, 36, 3874-3888.

Schreiber, H \& Schoenen, D. (1994). Chemical, bacteriological and biological examination and evaluation of sediments from drinking water reservoirs-results from the first sampling phase. Zbl Hygiene, 196, 153-169.

Sérodes, J-B., Rodriguez, M, Li, H. \& Bouchard, C. (2003). Occurrence of THMs and HAAs in experimental chlorinated waters of the Quebec City area (Canada). Ohemosphere, 51, 253-263.

Servais, P., Billen, G., Ventresque, C. \& Bablon, G. (1991). Microbial activity in GAC filters at the Choisy-le-Roi treatment plant. J. Am Water Works Association, 83, 62-68.

Sobsey, M. (1989). Inactivation of health-related microorganisms in water by disinfection processes. Water Science Tedmology, 21, 179-195. 
Speert, D., Bond, M., Woodman, R \& Cumutte, J. (1994). Infection with Pseudomonas copacia in chronic granulomatous disease: role of nonoxidative killing by neutrophils in host defense. Joumal of Infectious Diseases, 170, 1524-1531.

Steinert, M. Hentschel, U. \& Hacker, J. (2002). Legiondla prempobila: an aquatic microbe goes astray. FEMS Microbiology Recieus, 26, 149-162.

Stoodley, P., Lewandowski, Z., Boyle, J. \& Lappin-Scott, H. (1998). Oscillation characteristics of biofilm streamers in turbulent flowing water as related to drag and pressure drop. Biotedondogy Bioengineering, 57, 536-544.

Sunna-Borgan, N. (1998). Microbial regrowth of water supplies in Amman distribution system and household water storage tanks. PhD Thesis. University of Newcastle uponTyne, England.

Suslow, T. (2000). Chlorine usage in the production and postharvest handling of fresh fruit and vegetables. [ n.p]: In D.A. McIaren (Ed.), Use of dhlorine based sanitizers and disinfectants in the food manufactuming industry. University of Nebraska Food Processing Center.

Swerdlow, D., Mintz, E., Rodriguez, M., Tejeda, E., Ocampo, C \& Espejo, L. et al. (1992). Waterborne transmission of epidemic cholera in Trujillo, Peru: lessons for a continent at risk Larket, 340, 28-32.

Symons, J., Bellar, T., Carswell, J., DeMarco, J., Krapp, K., \& Robeck, G. et al. (1975). National organics reconnaissance survey for halogenated organics. AWWA, 67, 634-648.

Szewzyk, U., Szewzyk, R, Manz, W. \& Schleifer, K. (2000). Microbiological safety of drinking water. A nmial Recieves Microbiology, S4, 81-127.

Tokajian, S. (2002). Regrowth of bacteria \& their genotypic identification in drinking water in Lebanon. PhD Thesis. University of Newcastle upon-Tyne, England.

Tokajian, S. \& Hashwa, F. (2003). Water quality problems associated with intermittent water supply. Water Science and Tedmology, 47, 229-234.

Truu, J., Talpsep, E., Heinaru, E., Stottmeister, U., Wand, H. \& Heinanu, A. (1999). Comparison of API $20 \mathrm{NE}$ and Biolog GN identification systems assessed techniques of multivariate analyses. Joumal of Microbiological Methods, 36, 193-201.

Vandamme, P., Holmes, B., Vancanneyt, M., Coenye, T., Hoste, B. \& Coopman, R. et al. (1997). Occurrence of multiple genomovars of Bumkholderia cepacia in cystic fibrosis patients and proposal of Bunkbolderia multiumans sp. nov. Int. J. Syst. Bacteridogy, 47, 1188-1200.

Van der Kooij, D. (1977). The occurrence of Pseudomonas spp. in surface water and in tap water as determined on citrate media. A ntonie wan Leenuenhoek, 43,187-197. 
Van der Kooij, D. (1988). Properties of Aeromonads and their occurrence and hygienic significance in drinking water. Zentralblatt fur Bakteridogie Mikrobiologie Hyg [B], 187, 1-17.

Van der Kooij, D., Hijnen, W. \& Kruithof, J. (1989). The effect of ozonation, biological filtration and distribution on the concentration of easily assimilable organic carbon (AOC) in drinking water. Ozone Science Engimeering 11, 297-311.

Van der Kooif, D. (1992). Assimilable organic carbon as an indicator of bacterial regrowth. $A W W A, 84,57-66$.

Van der Kooij, D. \& Hijnen W. (1995). Determination of the concentration of maltose and starch like compounds in drinking water by growth measurements with a well defined strain of a Flavobacterium species. A pplied En nimommental Microbidogy, 49, 765-771.

Volk, J. \& LeChevallier, M. (1999). Impacts of the reduction of nutrient levels on bacterial water quality in distribution systems. A pplied Eminonmental Microbiology, 65, 4957-4966.

White, G. (1972). Handbook of chlorination. New York: Van Nostrand Reinhold.

White, G. (1978). Disinfection of water and water for reuse. New York: Reinhold.

White, G. (1986). Chlorination of potable water, Ch. 6, pp. 256-393. In the handbook of chlorination (2nd ed.). New York: Van Nostrand Reinhold.

WHO. (1984). In guidelines for drinking water quality (1st ed., Vol. 2). Geneva, Switzerland: WHO.

WHO. (1993). In guidelines for drinking water quality (2nd ed.). Geneva, Switzerland: WHO.

WHO. (1998). Food safety issues: Surface decontamination of fruits and vegetables eaten raw: A review. In food Safety unit, Geneva, Switzerland: WHO.

Yoon, J. Choi, Y. Cho, S. \& Lee, D. (2003). Low trihalomethane formation in Korean drinking water. The Science of the Total Eniroment, 302,157-166. 


\section{Appendix}

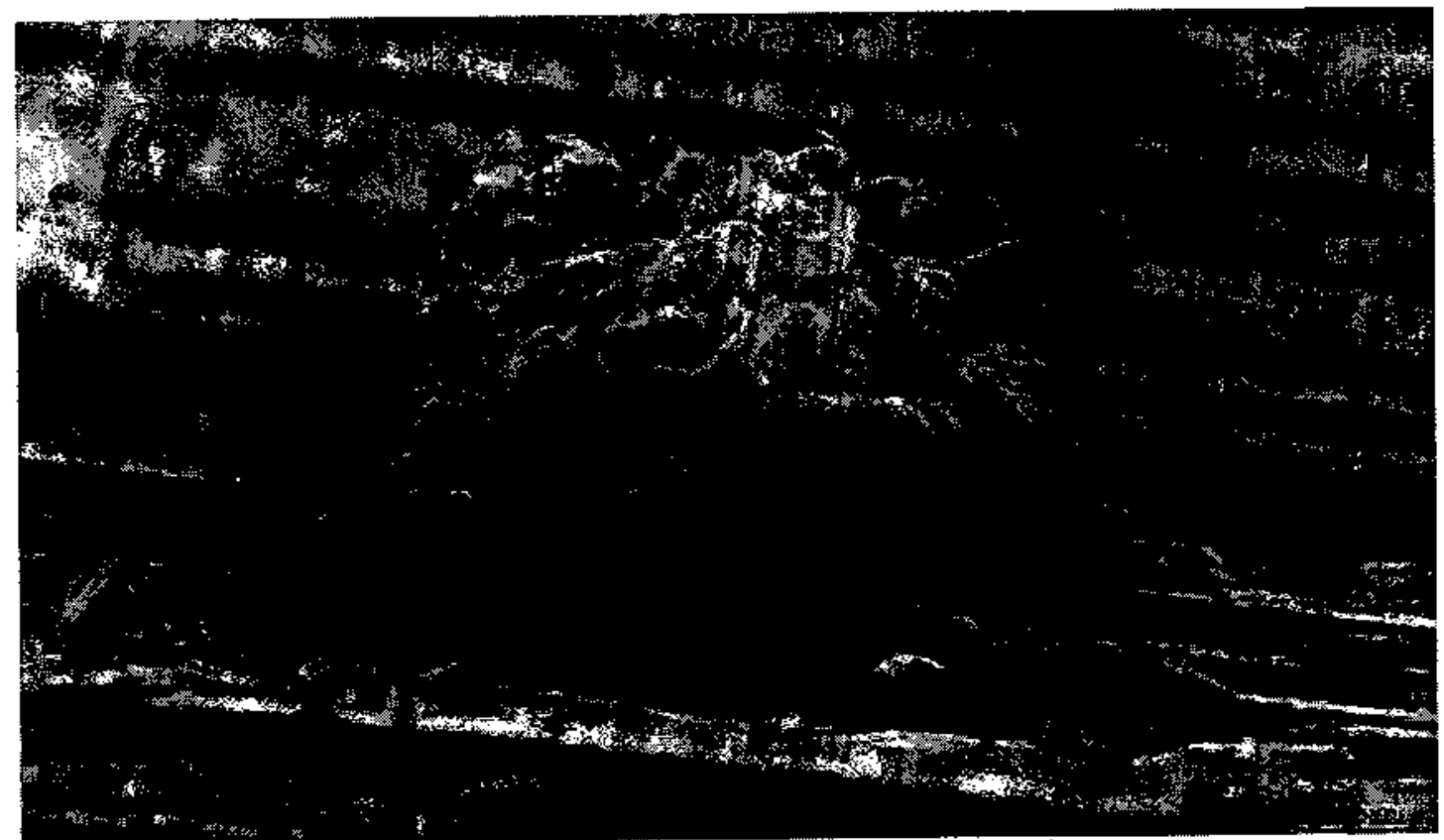

Figure 1: Scanning electron micrograph of a biofilm on a metal surface.

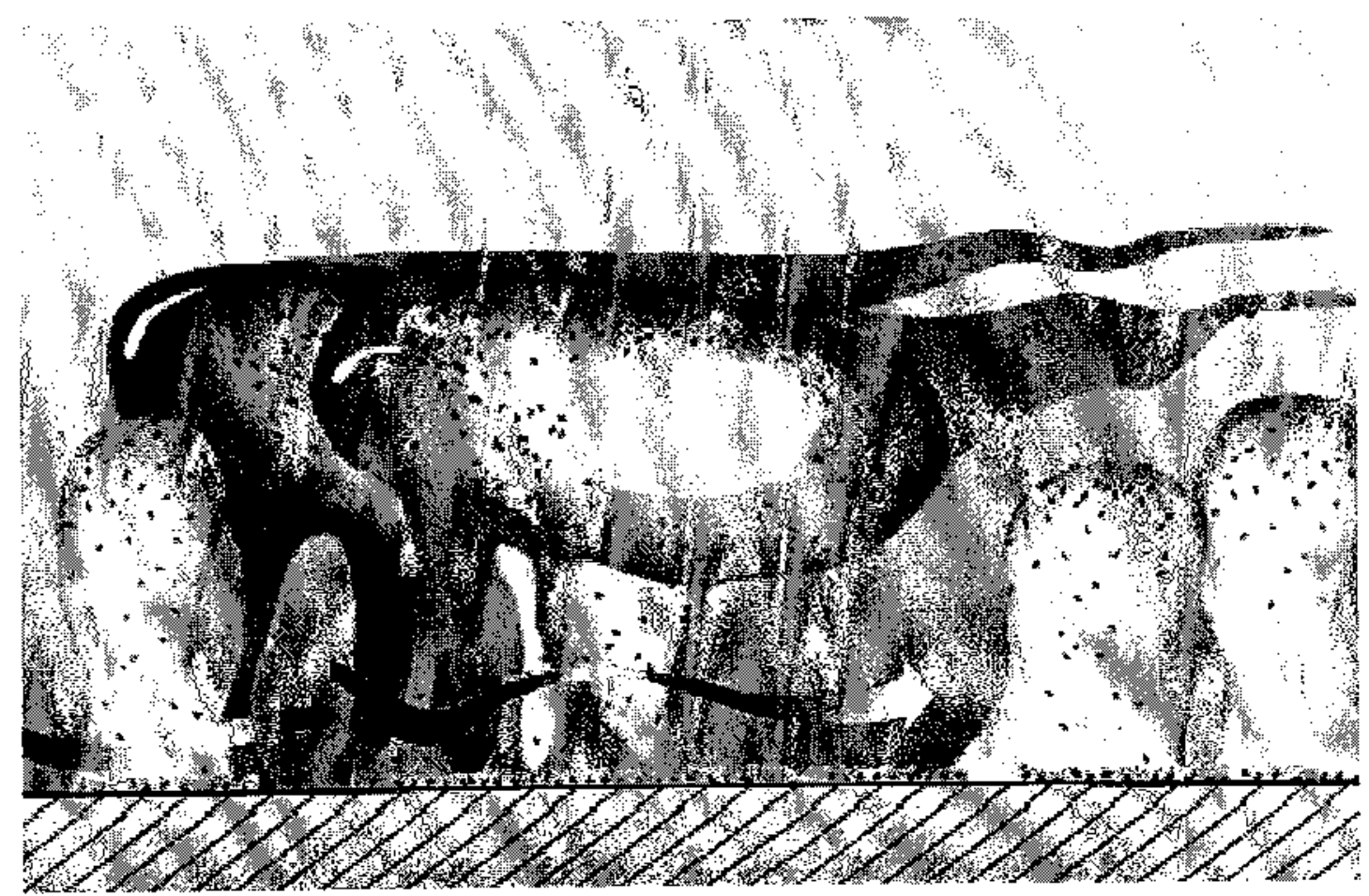

Figure 2: Biofilm structure cartoon. 


\section{Enterobacteriaceae Family ${ }^{*}$}

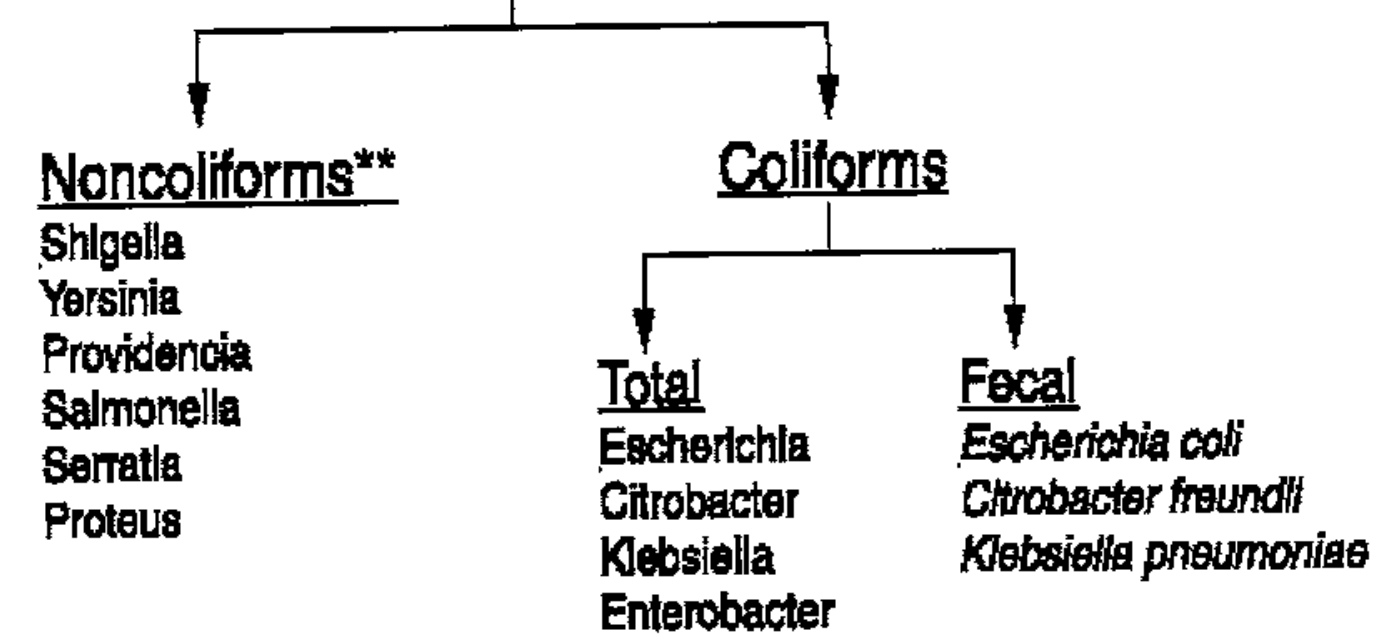

Figure 5: Enterobacteriaceae. Structure adapted from Bergey's Manual of Systemic Bacteriology, edited by Noel Krieg, Williams and Wilkins, 1984.

$* *$ Represent main genera.

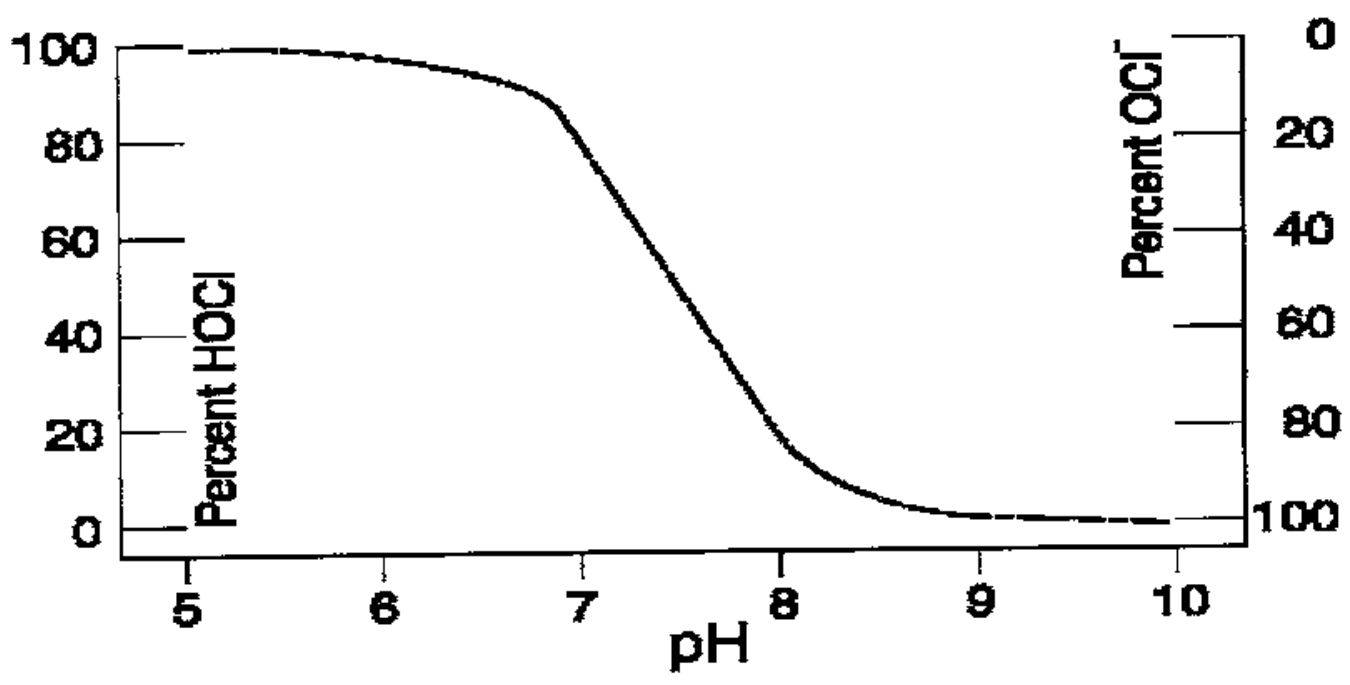

Figure 6: $\mathrm{pH}$ dependence of the species upon chlorination. 
Table 1: Identification of bacterial strains according to Biolog GN and API-20NE and API$20 \mathrm{E}$ for $24 \mathrm{~h}$ incubation ${ }^{2}$

\begin{tabular}{|c|c|c|c|c|}
\hline No. & Biolog id. & $\begin{array}{l}\text { Level of } \\
\text { certainty } \\
(\%)\end{array}$ & API $20 \mathrm{NE}$ and $20 \mathrm{E}$ id. & $\begin{array}{l}\text { Level of } \\
\text { Certainty } \\
(\%)\end{array}$ \\
\hline 1 & Adrombater dsdinophagum & 99.0 & n.i & - \\
\hline 2 & 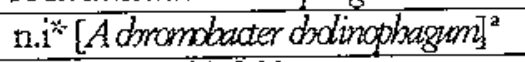 & 99.0 & n.i & - \\
\hline 3 & A idororax delafieldit & 99.0 & P. alcaligenes & 82.1 \\
\hline 4 & A cinet dhacter genosperies 11 & 95.0 & Buthbolderia apadia & 99.9 \\
\hline 5 & A eromonas zeronii/solria DNA op 8 & 98.0 & Odrobautrumanthopi & 99.0 \\
\hline 6 & A quaspinillum dispar & 93.0 & $\mathrm{n}, \overline{\mathrm{i}}$ & - \\
\hline 7 & Brezundimonas resicularis & 100 & $\begin{array}{l}\text { Brezundimonas resioularis } \\
\text { P. wesicularis (dd) }\end{array}$ & 99.7 \\
\hline 8 & Bumkholderia cocozenenans & 100 & A inetchater lwedfi & 49.5 \\
\hline 9 & n.i $[\text { Burkholderia cooouenenars }]^{3}$ & 100 & A cinetobader larffi & 62.2 \\
\hline 10 & Butkbolderia coocuerenans & 100 & n.i & - \\
\hline 11 & Buokbolderia ijetnamensis & 100 & Sphingobacterium multizonm & 93.6 \\
\hline 12 & Citrokader braakii & 100 & Citrobacter freumdii & 99.0 \\
\hline 13 & Enterobacter doacae & 100 & Enterchacter sakazakü & 76.0 \\
\hline 14 & Enterdatater gergoriate & 98 & Enterdacter spp. & 88.0 \\
\hline 15 & Erreiria canotowora ss betanasculonm & 100 & n.i & - \\
\hline 16 & Flawbacterium fermigineum & 66.0 & n.i & - \\
\hline 17 & Flawobacteriumjohnocriae & 100 & Sphingomonas paucimoblis & 76.0 \\
\hline 18 & Moraxella oloensis & 88.0 & Weeksella uinesa & 47.7 \\
\hline 19 & Pastemella tredalosi & 65.0 & $\begin{array}{l}\text { Empedobacter brezis } \\
\text { (Flawdbacterim brew) }\end{array}$ & 66.0 \\
\hline 20 & Pastemella trebalosi & 65.0 & Pastermella baemdytica & 94.0 \\
\hline 21 & Pasteurella pnetmotropica & 76.0 & Pastemella baemdytica & 87.0 \\
\hline 22 & n.i [pastetmella treballosi $]^{3}$ & 99.0 & n.a (dead organism) & - \\
\hline 23 & 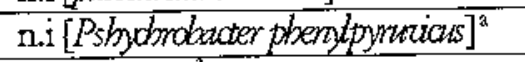 & 82.0 & P. djlororaphis & 73.0 \\
\hline 24 & P. aenuginos $a^{3}$ & 98.0 & P. aeniginosa ${ }^{3}$ & 99.9 \\
\hline 25 & $P$. alcalizenes ${ }^{2}$ & 96.0 & P. alcaligenes & 81.6 \\
\hline 26 & P. citronelldis & 99.0 & A loaligenes fecalis & 80.0 \\
\hline 27 & P. finomescens & 99.0 & Weeksella irosa & 48.0 \\
\hline 28 & P. fluorescens & 82.0 & A loaligenes fecalis & 98.2 \\
\hline 29 & P. fluonescens & 95.0 & n.i $[\text { A grobacterium radioladter }]^{a}$ & 99.8 \\
\hline 30 & P. finorescens Bidype $A$ & 100 & P. fluorescens & 97.0 \\
\hline 31 & $\begin{array}{l}\text { Pseudomonas sp. } \\
\text { [P. funorescens BiatypeF] }^{2}\end{array}$ & - & n.i. & $=$ \\
\hline 32 & P. mendocina & 100 & Sphingobacterium multivorum & 99.7 \\
\hline 33 & P. psendoalcaligenes & 99.0 & P. stutzeri & 94.0 \\
\hline
\end{tabular}




\begin{tabular}{|c|c|c|c|c|}
\hline$\overline{32}$ & P. mendocina & 100 & Sphingobacterium miltizonm & 99.7 \\
\hline 33 & P. psendoalsaligenes & 99.0 & P. stutzeri & 94.0 \\
\hline 34 & P. putida Bionype $A$ & 97.0 & P. putida & 98.0 \\
\hline 35 & $\begin{array}{l}\text { P. putida } \\
{[P \text {. putida Biotype A }]^{2}}\end{array}$ & $\begin{array}{l}82.0 \\
{[93.0]}\end{array}$ & n.i & - \\
\hline 36 & Pseudomonas spp. & - & {$\left[P_{\text {sendomonas spp. }}\right]^{b}$} & 81.0 \\
\hline 37 & P. stutzent & 100 & P. stutzeri & 98.0 \\
\hline 38 & P. symatantha & 86.0 & Ercinia spp. & 98.6 \\
\hline 39 & P. synxantha & 87.0 & P. fluorescens & 84.0 \\
\hline 40 & P. synowatha & 87.0 & P. fluonescens & 89.0 \\
\hline 41 & n.i $/$ Viknio batrayl] & 98.0 & P. mescopbilica & 82.0 \\
\hline 42 & Vibrio matsdnikoüi & 97.0 & n.i & - \\
\hline 43 & Vibrio tubiasbii & 85.0 & P. resicularis & 99.7 \\
\hline 44 & Vibrio tubiashï & 87.0 & n.i & - \\
\hline 45 & n.i [Vibno tubiasbij] ${ }^{\mathrm{a}}$ & 79.0 & A eromonas solvia & 99.6 \\
\hline 46 & n.i & - & n.i $[\text { Agrobacterium radidbater }]^{2}$ & 99.8 \\
\hline 47 & $n . \mathrm{i}$ & - & P. aesicularis & 93.0 \\
\hline 48 & $n . \mathrm{i}$ & - & $\begin{array}{l}\text { Empedobacter bretis } \\
\text { (Flaubacterium breze) }\end{array}$ & 53.0 \\
\hline 49 & n.i & $\therefore$ & Flawobacterium inddogenes & 99.7 \\
\hline 50 & $n, i$ & - & $\begin{array}{l}\text { A lcaligenes xyloscoxydars } \\
x_{3} l o s 0 x y d a r s\end{array}$ & 88.0 \\
\hline
\end{tabular}

a In brackets are shown $48 \mathrm{~h}$ or more designations if different from $24 \mathrm{~h}$ results. Biolog GN identification is acceptable if the similarity index is equal to or greater than 0.5. API-20NE \& API-20E identification is considered acceptable if the level of certainty is equal to or greater than $80 \%$.

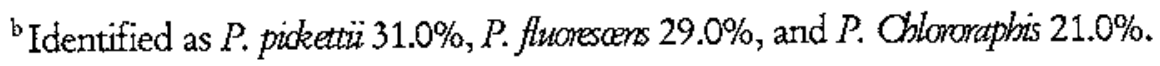

${ }^{2}$ Two organisms of $P$. alcaligenes were similarly identified on API and Biolog.

${ }^{3}$ Three organisms of $P$. aeruginosa were similarly identified on API and Biolog.

${ }^{5}$ Five organisms of $P$. stutzeri were similarly identified on API and Biolog.

*n.i: not identified 